\author{
UNIVERSIDADE DE SÃO PAULO \\ FACULDADE DE CIÊNCIAS FARMACÊUTICAS \\ Programa de Pós-Graduação em Ciência dos Alimentos \\ Área de Bromatologia
}

\title{
Qualidade e inocuidade alimentar na seção de rotisseria em supermercados: um estudo crítico
}

\author{
Cristina Cleto Barboza Garcia
}

Dissertação para obtenção do grau de MESTRE

Orientador:

Profa.Dra Bernadette D.G.M.Franco

SÃO PAULO

2005 


\section{DEDALUS - Acervo - CQ

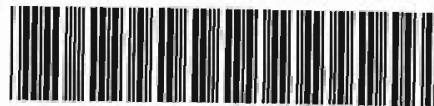 \\ 30100011104}

\section{Ficha Catalográfica}

Elaborada pela Divisào de Biblioteca e

Documentaçào do Conjunto das Quinicas da USP.

Garcia, Cristina Cleto Barboza
Qualidade e inocuidade alimentar na seçào de rotisseria em
supermercados: um estudo crítico / Cristina Cleto Barboza
Garcia -- Sào Paulo, 2005.
$112 p$.
Dissertaçào (mestrado) - Faculdade de Ciências Farmacêuticas
da Universidade de Sào Paulo. Departamento de Alimentos
e Nutrição Experimental
Oricntador: Franco. Bernadette Dora Gombossy Mclo
1. Higiene dos alimentos : Ciência dos alimentos 2. Manipulaçào
de alimentos: Tecnologia 3. Alimento: Controle de qualidade :
Saúde pública I. T. II. Franco, Bcrnadelte Dora Gombossy
Melo, orientador


Cristina Cleto Barboza Garcia

\title{
Qualidade e inocuidade alimentar na seção de
} rotisseria em supermercados: um estudo crítico

\author{
Comissão Julgadora \\ da \\ Dissertação para obtenção do grau de Mestre \\ Profa.Dra. Bernadette Dora Gombossy de Melo Franco \\ orientador/presidente \\ 10. Examinador \\ $2^{\circ}$. Examinador
}

São Paulo, de 2005 
À minha família.

Aos meus amados filhos Bruno, Livia e Clara. Ao Carlos, meu amor e marido. À minha mãe e meus irmãos. Ao meu pai in memoriam.

Dedico a vocês a realização deste sonho! 


\section{AGRADECIMENTOS}

Inicialmente agradeço a Deus, pela inspiração e força durante este trabalho.

À minha mestre e orientadora Profa.Dra Bernadette, por ter me dado a oportunidade de realizar este trabalho e de aprender muito!

Ao Mário Killner e toda equipe do SFDK, que graciosamente realizou as análises laboratoriais.

Ao Sussumu Honda, por sempre acreditar no meu trabalho.

À todos amigos da APAS e MULHER APAS, pelo apoio durante a realização deste estudo e na realização de muitos outros projetos.

Ao Toni e sua equipe, por toda sua atenção e disponibilidade.

À Elis do Instituto Histórico da Abras, por sua ajuda na pesquisa bibliográfica.

Aos Professores Evelise e Pedro Germano, por suas preciosas observações e orientaçōes.

Às amigas Rosa e Catarina, pela amizade e dicas.

E finalmente, a todos que de uma forma ou outra me ajudaram a realizar este projeto, o meu muito obrigado! 
"Eis o meu segredo. É muito simples: só se vê bem com o coração. O essencial é invisivel para os olhos. Os homens esqueceram essa verdade. Mas tu não deves se esquecer. Tu te tornas responsável por aquilo que cativas."

O Pequeno Príncipe de Antonie de Saint-Exupéry 


\section{LISTA DE ABREVIATURAS}

ABIA -Associação Brasileira da Indústria de Alimentos

ABNT- Associação Brasileira de Normas Técnicas

ABRAS- Associação Brasileira de Supermercados

ALAS- Associação Latino-Americana de Supermercados

ANVISA- Agência Nacional de Vigilância Sanitária

APAS- Associação Paulista de Supermercados

BPF- Boas Práticas de Fabricação

BPM- Boas Práticas de Manipulação

CDC- Centers for Diasese Control and Prevention

CFSAN- Center for Food Safety and Applied Nutrition

CVE- Centro de Vigilância Epidemiológica

CVS - Centro de Vigilância Sanitária

DDTHA- Divisão de Doenças de Transmissão Hídrica e de Alimentos

DIMA- Divisão Municipal de Alimentos

FDA- Food and Drug Administration

FEA - Faculdade de Economia e Administração

FIA - Fundação Instituto de Administração

FLV- Frutas, Legumes e Verduras

FMI - Food Marketing Institute

IDEC- Instituto de Defesa do Consumidor

IFT- Institute of Food Technologists

OMS- Organização Mundial da Saúde

PROVAR- Programa de Administração de Varejo 
RDC- Resolução de Diretoria Colegiada

SMS- Secretaria Municipal de Saúde

USDA- United State Department of Agriculture

WHO- World Health Organization 


\section{LISTA DE FIGURAS}

Figura 1 Estrutura do sistema da qualidade para alimentos e bebidas.

Figura 2 Como consumidores tomam decisões para bens $e$ serviços

Figura 3 Esquema de canal de distribuição para bens de consumo.

Figura 4 Layout do setor de perecíveis dentro de um supermercado

Figura 5 Foto das preparações lagarto a escabeche e lagarto com aliche

Figura 6 Fluxograma de preparo do lagarto a escabeche e lagarto com aliche

Figura 7 Foto da carne assada na área de vendas da 55 rotisseria

Figura 8 Fluxograma do preparo da carne assada com molho ferrugem

Figura 9

Fluxograma

do preparo

da

batata aperitivo

Figura 10 Fluxograma do preparo da maionese de legumes 
Figura 11 Fluxograma do preparo da farofa de carne

Figura 12 Resultados da Lista de Verificação das Boas Práticas de Manipulação em Estabelecimento de Alimentos.

Figura 13 Foto da localização da cozinha da rotisseria.

Figura 14 Foto da vista da cozinha da rotisseria e alguns equipamentos

Figura 15 Foto da vista da cozinha da rotisseria em supermercado com destaque para mesa de apoio e geladeira

Figura 16 Foto de sanitário feminino

Figura 17 Foto da área de vendas de alimentos prontos antes do início do serviço.

Figura 18 Foto da área de vendas de alimentos da rotisseria no momento da arrumação das travessas

Figura 19 Foto de utensílios e local de higienização na cozinha da rotisseria.

Figura 20 Foto de móveis e utensílios da cozinha da rotisseria.

Figura 21 Foto de equipamento - amaciador de carne

Figura 22 Foto de termômetro na medição de temperatura da geladeira da cozinha da rotisseria. 
Figura 23 Foto de funcionários da cozinha da rotisseria preparando maionese de legumes

Figura 24 Foto de funcionária da cozinha da rotisseria cortando legumes.

Figura 25 Foto de carne assada em temperatura ambiente na cozinha da rotisseria.

Figura 26 Foto de funcionária cortando carne assada para expor na área de vendas.

Figura 27 Foto de funcionária da cozinha acrescentando molho à carne assada para expor na área de vendas

Figura 28 Foto de medição de temperatura da carne assada com molho para exposição à venda

Figura 29 Foto de produto pronto frango assado com batatas para exposição na área de vendas da rotisseria

Figura 30 Foto de frango assado exposto à venda na seção de rotisseria.

Figura 31 Foto da área de vendas de alimentos da rotisseria com destaque para carne assada com molho ferrugem, frango a passarinho $e$ lasanha.

Figura 32 Foto da cozinha da rotisseria em supermercado com destaque para mesa de apoio de embalagem 


\section{LISTA DE TABELAS}

Tabela 1 Classificação dos estabelecimentos varejistas de alimentos.

Tabela 2 Resultado de análise microbiológica de alimentos preparados e expostos à venda no dia 08/12/2003

Tabela 3 Resultado de análise microbiológica de alimentos preparados e expostos à venda no dia 09/12/2003

Tabela 4 Resultado de análise microbiológica de alimentos preparados e expostos à venda no dia 15/12/2003

Tabela 5 Resultado de análise microbiológica de alimentos preparados e expostos à venda no dia 17/12/2003

Tabela 6 Resultado de análise microbiológica de alimentos preparados e expostos à venda no dia 22/01/2004

Tabela 7 Resultado de análise microbiológica de alimentos preparados e expostos à venda no dia 27/01/2004

Tabela 8 Resultado de análise microbiológica de alimentos preparados e expostos à venda no dia 28/01/2004

Tabela 9 Resultado de análise microbiológica de alimentos preparados e expostos à venda no dia 11/02/2004 


\section{SUMÁRIO}

RESUMO i

ABSTRACT ii

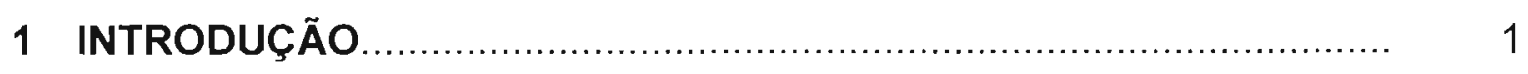

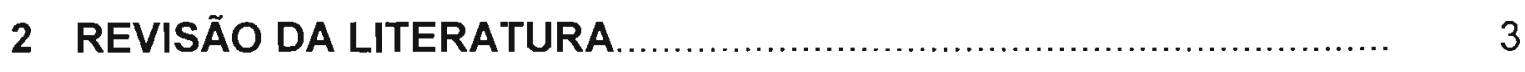

2.1- Doenças Transmitidas por Alimentos.................................... 3

2.2- Perigos em Alimentos.................................................. 5

2.3- Histórico da Alimentação................................................. 8

2.4- Qualidade........................................................... 15

2.5- Segurança Alimentar e Segurança dos Alimentos no Brasil........... 17

2.6- Sistemas de Gestão da Qualidade e Segurança dos Alimentos.... $\quad 20$

2.7- Consumidor ....................................................................... 23

2.7.1- Mudanças no comportamento do Consurridor em relação a



2.7.2- Pesquisas sobre hábitos e percepção dos consumidores............. 27

2.8- Supermercados..................................................... $\quad 34$

2.8.1- Definições, Legislação e Layout......................................... 34

2.8.2- Seção de Rotisseria.............................................................. 43

2.8.3- Dados Atuais do Setor Supermercadista.............................. $\quad 49$

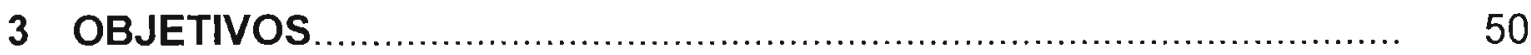

4 MATERIAIS E MÉTODOS ....................................................... 51

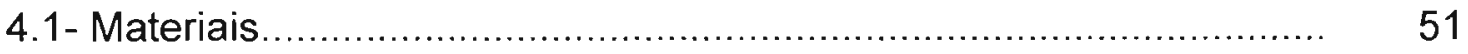

4.1.1- Descrição das Preparações.............................................. 52

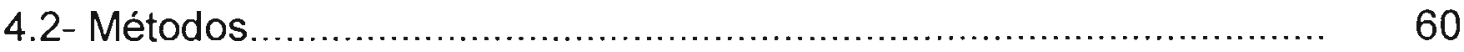




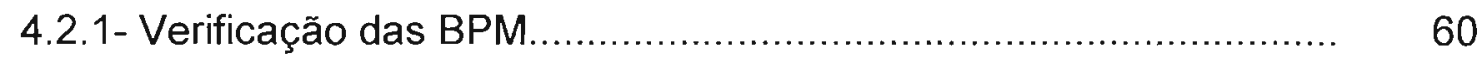

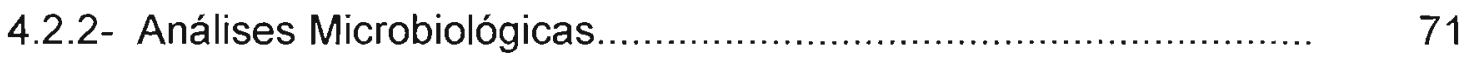

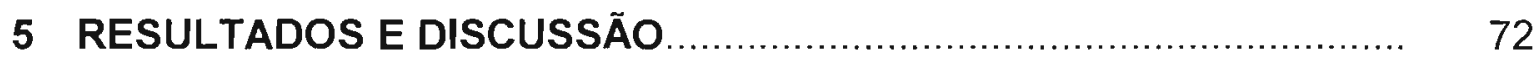

5.1- Resultados da Lista de Verificação das BPM........................... 72

5.2- Resultados de Analises Microbiológicas................................... 88

5.3- Interpretação dos Resultados............................................. 95

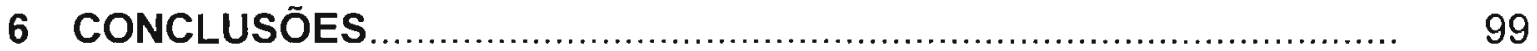

7 REFERÊNCIAS BIBLIOGRÁFICAS ........................................ 100 ANEXOS 


\section{RESUMO}

GARCIA, C. C. B. Qualidade e inocuidade alimentar na seção de rotisseria em supermercados: um estudo crítico. 2005. 112 f. Dissertação (Mestrado) - Faculdade de Ciências Farmacêuticas, Universidade de São Paulo, São Paulo, 2005.

A vida moderna impôs novos hábitos alimentares para a população e a maior participação da mulher no mercado de trabalho estimula a alimentação fora do lar. Buscando diversificar suas atividades comerciais e atender esse mercado crescente, muitos supermercados estão implantando uma seção de rotisseria, no qual são produzidos e comercializados alimentos prontos para o consumo. Em muitos supermercados, essa seção é improvisada, sem atender as Boas Práticas de Manipulação, podendo representar um perigo à saúde dos consumidores. Os objetivos deste trabalho foram fazer um estudo crítico do problema da qualidade e inocuidade alimentar na seção de rotisseria de supermercados e apresentar um exemplo de um estabelecimento na cidade de São Paulo no qual uma área foi adaptada para uma rotisseria. Nessa rotisseria improvisada, aplicou-se a Lista de Verificação das Boas Práticas de Manipulação em Estabelecimentos da Área de Alimentos (LVBPMEA) da Prefeitura Municipal de São Paulo e alguns produtos colocados à venda foram submetidos à análises microbiológicas, para verificar se atendiam os padrões microbiológicos legais vigentes (Resolução RDC12 item 22, ANVISA). O estudo indicou que rotisserias em supermercados representam um novo e promissor mercado, mas os supermercadistas necessitam compreender que esse setor necessita de atenção diferenciada, por envolver produtos de alto risco para a saúde da população. Essa necessidade foi comprovada pelos resultados obtidos no supermercado estudado, onde numerosos pontos da LVBPMEA e da RDC12 não foram atendidos. Este exemplo pode refletir a realidade de muitos supermercados no Brasil.

DESCRITORES: QUALIDADE DE ALIMENTOS, INOCUIDADE ALIMENTAR, ROTISSERIA, SUPERMERCADO, BOAS PRÁTICAS DE MANIPULAÇÃO 


\section{ABSTRACT}

GARCIA, C. C. B. Food quality and safety in the rotisserie section in supermarkets: a critical study. 2005. 112 f. Dissertação (Mestrado) - Faculdade de Ciências Farmacêuticas, Universidade de São Paulo, São Paulo, 2005.

Modern life style is imposing new eating habits and the increased participation of women in the work market estimulates having meals outside the home. Envisaging a new and promising market, supermarkets are adapting areas for preparation and selling of meals (rotisseries). In many supermakets, these improvised areas do not follow the recommended Good Manufacturing Practices, endangering consumers health. The present study aimed to address the issue concerned to quality and safety of meals prepared in these rotisseries, and present an example of a supermarket in the city of São Paulo in which an area was transformed in a rotisserie for cooking and selling ready-to-eat foods. The Good Manufacturing Practices Verification List, of the Mayority of São Paulo city, was applied to this improvised rotisserie, and some samples of ready-to-eat foods were submitted to microbiological testing in order to evaluate their compliance with the legal Brazilian microbiological standards (Resolução RDC12 item 22, ANVISA). The review indicated that rotisseries in supermarkets are a growing market in Brazil, but the managers need to understand that this sector needs special attention because the foods for sale may be risky for the consumers health. The need for special attention was strenghtened by the results in the studied supermarket, where many points and products were not in accordance with the GMP Verification list and the legal Brazilian microbiological standards. This example may reflect the reality in many supermarkets in Brazil.

KEY WORDS: FOOD QUALITY, FOOD SAFETY, ROTISSERIE, SUPERMARKETS, GMP. 


\section{1 - INTRODUÇÃO}

Nos últimos dez anos, a venda de pratos prontos ou alimentos preparados no varejo alimentício cresceu em torno de 100\% (CARVALHO, 2005). As áreas de rotisserias ou pratos prontos dentro de supermercados são o segmento de mercado que mais cresce atualmente, decorrente de uma realidade de consumidores que estão mudando de hábitos no preparo e consı:mo de alimentos.

O food service é um termo genérico adotado intencionalmente para designar alimentação fora do lar. O canal de food service é definido como qualquer estabelecimento público ou privado que tenha o serviço de venda de alimentos prontos, com a intenção de serem consumidos tanto dentro como fora deste local (ABIA, 2004). Com a publicação da Resolução RDC N²16 da ANVISA, estes locais passaram a ser denominados Serviços de Alimentação, compreendendo alimentos que são manipulados, preparados, armazenados e/ou expostos à venda, podendo ou não ser consumidos no local (BRASIL, 2004).

Neste estudo, os termos rotisseria ou pratos prontos foram utilizados indiferentemente, porém o termo consagrado pelo setor supermercadista é "rotisseria", correspondente ao local de preparação e venda de pratos prontos para o consumo, como frango assado, lasanha, arroz, feijão, saladas e outros alimentos prontos.

Para atender um novo mercado de consumidores, um grande número de supermercados e hipermercados implantou um serviço de rotisseria em áreas improvisadas dentro do estabelecimento, sem atentar para a especificação da 
estrutura física e equipamentos e outras adequações necessárias para implantação deste serviço, como a capacitação de manipuladores em higiene de alimentos e a presença de profissional responsável técnico (RT) neste setor (BRITO, 2004).

Segundo o Institute of Food Technologists, muitos surtos de Doenças Transmitidas por Alimentos (DTA) estão associados com alimentos manipulados e comercializados prontos para o consumo na forma de refeições. As principais causas do envolvimento destes alimentos em surtos de DTA podem ser o preparo em condições inadequadas de higiene geral (pessoal, ambiental e dos alimentos), cocção inadequada dos alimentos, falta de controle de temperatura dos alimentos prontos para o consumo, matéria prima proveniente de fonte insegura, entre outras falhas (IFT, 2004).

Conforme resultados apresentados pelo Centro de Vigilância Epidemiológica do Estado de São Paulo (CVE SP) e pela Secretaria Municipal de Saúde (Setor de Vigilância Sanitária de Alimentos) de São Paulo, os alimentos normalmente implicados em surtos de DTA são preparações como arroz, feijão, carne assada, frango assado, farofa, maionese de legumes, salgados assados ou fritos, dentre outras preparações que podem ser comercializadas em supermercados no setor de rotisseria (CVE, 2003).

Doenças transmitidas por alimentos contaminados são responsáveis por expressivas perdas financeiras tanto para os individuos que contraem a doença, quanto para seus familiares, empregadores e para os orgãos oficiais de saúde. Além disto, estas doenças podem deixar sérias conseqüências como seqüelas crônicas no indivíduo, levando à perda de produtividade e elevados custos de tratamento médico (PRAXEDES, 2003; HANASHIRO, 2002). Para as empresas envolvidas em casos de DTA, as conseqüências negativas podem ser associadas com despesas 
em processos legais, indenizações, multas, perda da licença de funcionamento, prejuizo para a marca e perda de confiança dos consumidores pelo estabelecimento onde realizam suas compras (ABRAS, 2000, 2001). Estas conseqüências podem ser tão graves que podem provocar o fechamento definitivo da empresa (DIMAVSEMAB/PMSP, 2002).

O tema segurança alimentar relacionado à inocuidade de alimentos é ainda pouco explorado no setor varejista de alimentos, embora esse setor represente $89,1 \%$ das vendas do auto-serviço e $5,8 \%$ do PIB brasileiro (PARENTE, 2000). Por essa razão, este estudo é de grande relevância para a sociedade, haja vista que o setor supermercadista é o maior distribuidor de alimentos para a população, gerando inúmeras oportunidades de trabalho e trazendo grande benefício sócio-econômico. Porém, pessoas que atuam nesse setor nem sempre estão devidamente qualificadas para manipular alimentos, abrindo um flanco que pode representar um grave risco para a saúde de consumidores.

\section{2 - REVISÃO DA LITERATURA}

\section{1 - DOENÇAS TRANSMITIDAS POR ALIMENTOS}

A Organização Mundial da Saúde define Doença Transmitida por Alimentos como uma doença de natureza infecciosa ou tóxica causada por agentes que entram no organismo por meio da ingestão de alimentos ou água (OMS, 2002).

As Doenças Transmitidas por Alimentos (DTA) destacam-se por sua relevância na saúde da população (ZANARDI, 2002). Nos EUA, estima-se que as DTAs causam 5.000 mortes e 76 milhões de doentes/ ano (FMI, 2004). No Brasil não existem dados confiáveis sobre a ocorrência de DTAs, mas sabe-se que em São Paulo, no ano de 2003, ocorreram 1008 casos, conforme notificação à Divisão de 
DDTHA - CVE (Secretaria de Saúde do Estado de São Paulo), (CVE-SP, 2003). Este número de casos é subestimado, haja vista que a notificação aos Centros de Controle de Doenças nem sempre é realizada (FORSYTHE, 2002; AFIC, 2000). Esse problema não é exclusivo do Brasil. Segundo Forsythe (2002), apenas um pequeno número de casos de enfermidades causadas por alimentos é notificado aos orgãos competentes. Isso se deve, em parte, ao fato de que alguns patógenos presentes em alimentos causam sintomas brandos, e as vítimas não buscam auxílio médico. A percepção das pessoas em relação à DTA também pode variar em função da cultura ou nível de informação que possuem. Muitos consumidores podem não relacionar a doença diarréica com a ingestão de alimentos prontos, atribuindoa a mistura inadequada de alimentos, início da dentição em crianças ou mesmo superstição (KAWASAKI, 2003).

Em nosso pais, as DTAs têm relação direta com o desenvolvimento sócioeconômico de cada região em particular. O grande problema ainda reside nas precárias condições sanitárias, com deficiências no abastecimento de água tratada e na coleta de esgoto e de lixo, principalmente nas regiões Norte e Nordeste e na periferia das grandes cidades do Sul e Sudeste (KAWASAKI, 2003). As doenças infectantes e parasitárias intestinais são uma das maiores causas de mortalidade em crianças menores de 5 anos. Parte está relacionada ao consumo de alimentos e a água contaminados por microorganismos e helmintos patogênicos, que associados a um quadro de desnutrição, resultam em grave quadro de saúde pública (ALENCAR, 2002).

Outros fatores comumente associados às doenças transmitidas por alimentos incluem as mudanças das características demográficas de algumas regiões, modo de preparo e consumo de alimentos, tecnologia empregada desde a produção até a 
comercialização dos alimentos, tendências globais de mercado e mecanismos de virulência e adaptação dos microrganismos (ZANARDI apud ALTEKRUSE et al. 1997).

Os sintomas da maioria das doenças de origem alimentar estão relacionados com perturbações gastrintestinais. Dependendo da patogenicidade do microrganismo envolvido e do estado geral de saúde do indivíduo afetado, a doença pode ser aguda, podendo ser autolimitada ou causar óbito, ou então pode se tornar crônica. Algumas doenças de origem alimentar podem não se limitar ao trato gastrintestinal, mas afetar outros orgãos e causar distúrbios no sistema nervoso, na corrente circulatória, no aparelho genital e fígado (FRANCO e LANDGRAF, 1996).

\section{2 - PERIGOS EM ALIMENTOS}

De acordo com o Codex Alimentarius, os perigos podem ser definidos como agentes de origem física, química ou biológica, capazes de causar um efeito adverso à saúde (SILVA, Jr. 2001; FRANCO e LANDGRAF, 1996). Esses agentes podem aparecer durante o processo de produção, transporte, preparação, armazenagem ou distribuição de qualquer alimento ou bebida (ALENCAR, 2002).

Entre os perigos biológicos destacam-se as toxinas naturais de plantas e de animais, vírus, parasitas, bactérias patogênicas e fungos toxigênicos (FRANCO, 2004).

Nos EUA, dos 76 milhões de casos estimados de DTAs que ocorrem por ano, menos de 14 rnilhões têm sua origem conhecida, sendo que em $30 \%$ destes casos identificados, as bactérias são o agente causador (IFT, 2004). Segundo o FMI (Food Marketing Institute), apesar do alto índice de casos de DTA ocorridos entre 1996 e 2003, foram obtidos alguns progressos no controle dessas doenças. Baseado em 
dados do CDC (Centers for Disease Control and Prevention), o FMI reporta uma diminuição no número de casos por Campylobacter em 28\%, E.coli O157:H7 em 42\%, Yersina em 49\%. Em relação à Salmonella a variação foi conforme a espécie: para S.Typhimurium, houve uma diminuição enquanto de $17 \%$, para S.Enteritidis, S.Newport e S.Heidelberg houve pouca diminuição, enquanto que para S.Javiana houve um aumento de $227 \%$ (FMI, 2004).

Vários fatores determinam a sobrevivência ou a multiplicação dos microrganismos em um alimento. Entre estes fatores, existem os relacionados com as características próprias dos alimentos (fatores intrínsecos) e os relacionados com o ambiente em que o alimento se encontra (fatores extrinsecos). São considerados fatores intrínsecos a atividade de água, a acidez, o potencial de óxido-redução, a composição química, a presença de fatores antimicrobianos e as interações entre os microrganismos presentes nos alimentos. Entre os fatores extrinsecos, os mais importantes são a umidade e a temperatura ambiente, como também a composição quimica da atmosfera que envolve o alimento (FRANCO e LANDGRAF, 1996).

Os microrganismos podem multiplicar-se em uma faixa bastante ampla de temperatura, e de acordo com a temperatura ideal de multiplicação são classificados em:

- Psicrófilos

Temperatura ótima de multiplicação: de $10^{\circ} \mathrm{C}$ a $15^{\circ} \mathrm{C}$

- Psicrotróficos

Temperatura ótima de multiplicação: de $20^{\circ} \mathrm{C}$ a $30^{\circ} \mathrm{C}$

- Mesófilos

Temperatura ótima de multiplicação: de $30^{\circ} \mathrm{C}$ a $45^{\circ} \mathrm{C}$

- Termófilos

Temperatura ótima de multiplicação: de $55^{\circ} \mathrm{C}$ a $75^{\circ} \mathrm{C}$

(JAY, 2000; SILVA Jr., 2001) 
A temperatura é um dos fatores extrínsecos mais importantes na sobrevivência e multiplicação dos microrganismos porque quanto mais baixa a temperatura menor é a velocidade das reações bioquímicas. Temperaturas elevadas causam a destruição dos microrganismos pela desnaturação das proteínas e inativação das enzimas necessárias para o seu metabolismo. Cada tipo de microrganismo possui características próprias de resistência ao calor e ao tempo de exposição e por esta razão, o binômio tempo e temperatura é o mais estudado em todo o mundo como forma de controlar o número de microrganismos durante o processamento, manipulação e distribuição dos alimentos para o consumo (SILVA $J r, 2001)$.

Estudos realizados por Bryan $(1978,1988)$ para identificação dos fatores contribuintes para ocorrência de surtos de doenças transmitidas por alimentos em serviços de alimentação nos EUA, bem como informações do CDC e de outras publicações científicas, revelam que entre as cinco causas principais, quatro estão relacionadas à falhas no controle da temperatura do alimento e do tempo entre o momento de preparação e o consumo. A primeira causa é a refrigeração inadequada; a segunda é o preparo antecipado do alimento com um intervalo de doze ou mais horas entre a cocção e o consumo; a terceira está relacionada ao manipulador infectado por microrganismos patogênicos; a quarta é o reaquecimento inadequado do alimento e a quinta é a manutenção a quente inadequada.

A manutenção do alimento em temperaturas ótimas para a multiplicação bacteriana tem sido objeto de estudo e preocupação de autoridades. Em 2004, o FDA publicou um relatório sobre fatores de risco para ocorrência de doenças transmitidas por alimentos em instituições selecionadas do food service como restaurantes, varejistas de alimentos, e outras instituições como pré-escolas e asilos. 
Os dados foram coletados em 2003, durante 926 inspeções nestes locais, em diversas cidades dos EUA. Os dados atuais mostram que os mesmos fatores de risco identificados como problemáticos nestes locais no ano de 2000 permanecem necessitando atenção. Em todos os serviços os fatores de risco observados foram: a manutenção do alimento em tempo e temperatura inadequados e práticas deficientes de higiene pessoal e de equipamentos. No caso de empresas do setor varejista de alimentos, o abuso da exposição de alimentos em temperaturas impróprias foi a prática mais freqüente, tendo sido observada em $64,4 \%$ dos estabelecimentos considerados "fora de padrão" (FDA, 2004).

\section{3 - HISTÓRICO DA ALIMENTAÇÃO: DA CAÇA AOS PRATOS PRONTOS PARA O CONSUMO}

"Todo trabalho do homem é para sua boca"

Omnis labor hominis in ore eius. Ecclesiaastes, VI, T Luis da Câmara Cascudo

Segundo Cascudo (2004), saciar a fome é imperioso, inadiável e necessário durante toda a vida. Desde que nasce, o homem precisa obter na alimentação fontes de carboidratos, proteinas, gorduras, sais minerais e água, retirando esses elementos das carnes, dos vegetais, das frutas e de outros alimentos.

Na história da humanidade, observa-se que o homem teve que superar inúmeras e difíceis barreiras para conseguir se alimentar (FLANDRIN, 2000).

A conservação dos alimentos e as doenças causadas por ingestão destes são preocupações do homem desde os primórdios da humanidade.

O uso regular do fogo modificou profundamente a forma do homem se alimentar, assim como outros comportamentos sociais, não sendo mero acaso que 
a maneira de se preparar os mesmos alimentos difere de um povo para outro, em decorrencia de diferenças tecnológicas, econômicas e sociais.

No final da era glacial, populações nômades iniciaram a produção de alimentos através da agricultura e domesticação de pequenos animais como carneiros e cabras, garantindo a carne para consumo e suprimento de alimentos estáveis. A mobilidade dos rebanhos favorecia o abate na hora do consumo.

Após o homem ter aprendido a produzir pão, bebidas alcoólicas como vinho e cerveja, outros alimentos fermentados, carnes e peixes secos ou salgados, logo ele aprendeu que era necessário manter esses alimentos afastados do ar, luz e umidade (FRANCO e LANDGRAF, 1996). Para obter uma melhor conservação, passou a utilizar o barro, mel, óleo de oliva, sal e ervas aromáticas.

Com o surgimento dos centros urbanos e a diferenciação entre regiões produtoras e de consumo, a produção de alimentos passou a ser não apenas para consumo próprio, iniciando-se a prática de comercialização dos alimentos. Uma das principais conseqüências advindas do desenvolvimento de centros industriais é a migração, cada vez maior, da população rural para as zonas urbanas. Com o aumento da concentração humana nas regiões urbanas, constata-se o aumento da demanda alimentar e distanciamento progressivo entre as zonas produtoras de alimentos e os consumidores, alongando a cadeia alimentar (GERMANO e GERMANO, 2001).

$\mathrm{Na}$ sociedade moderna, onde o ritmo de vida é intenso, a utilização de métodos e utensílios capazes de agilizar e racionalizar o preparo de alimentos atraiu um grande número de consumidores, principalmente as mulheres que intensificavam suas atividades profissionais (TORRES e MACHADO, 2001). Porém, 
isto ainda não era suficiente para uma vida cada vez mais corrida e com pouco tempo para o preparo de refeições em casa.

A partir da industrialização dos alimentos, a distribuição para o mercado consumidor passou a ser em grande escala. A indústria passou a investir em pesquisas e tecnologia para diferenciar e aumentar a oferta de itens semi-prontos, tornando-os convenientes e de valor agregado (FLANDRIM, 2000).

Os precursores no mercado de alimentos semi-prontos foram os caldos e as sopas, disponíveis desde a década de 1970. Posteriormente, passam a surgir no mercado alimentos prontos congelados, acompanhados de forte apelo de marketing, no qual ressaltava-se suas inúmeras vantagens para os consumidores, como a praticidade, uso de matéria-prima selecionada, variedade e sabor - enfim, tornaramse "alimentos-serviço" (FLANDRIM, 2000).

As refeições congeladas surgiram como opção de solução para atender os consumidores com menos tempo para o preparo de refeições de forma tradicional, incluindo desde a compra de ingredientes, o pré-preparo (com seleção, higienização e corte) e o preparo em si (cocção através de diversos métodos). Estas operações podem levar muito tempo e podem não ser prazerosas para muitas pessoas, principalmente após um dia de trabalho intenso (CARVALHO, 2005).

Os primeiros produtos congelados lançados no mercado não tiveram grande impacto, mas com o passar do tempo, "caíram no gosto do consumidor". As campanhas e apelos de marketing foram cada vez mais fortes, com o uso de expressões chamativas, como por exemplo: "Do freezer para a mesa", "Práticos e variados". As preparações foram ficando cada vez mais sofisticadas e com grande número de opções, como por exemplo: estrogonofes, arroz com brócolis, nhoque a bolonhesa, feijoada e outros. Atualmente podem ser encontrados cerca de 60 tipos 
de produtos diferentes nos diversos supermercados do país, atraindo novos adeptos da praticidade, já que uma refeição completa, incluindo sobremesa, pode ser preparada em poucos minutos.

Dados da Associação Brasileira da Indústria Alimentícia mostram que entre 1994 e 2002 a produção de alimentos congelados triplicou e foi um dos setores que mais empregou no país (ABIA, 2004). A previsão é de crescimento na produção para os próximos anos, incluindo a exportação para vários paises. Atualmente, há uma grande procura por produtos que contenham carne bovina brasileira porque o Brasil é um pais onde não há relato de casos da doença da vaca louca (Encefalopatia Espongiforme Bovina) que vem afetando o rebanho bovino do Reino Unido (ANVISA, 2004).

Empresas especializadas na produção e venda de carnes e derivados sofisticaram a produção de pratos congelados. Com uma meta estabelecida de fazer novos lançamentos a cada ano, essas empresas contrataram renomados "chefs" de cozinha para o desenvolvimento de novos pratos, e realizaram pesquisas com consumidores nos principais restaurantes e lanchonetes de São Paulo, Rio de Janeiro e Porto Alegre antes dos lançamentos para saber quais eram os pratos mais pedidos nesses estabelecimentos (PERDIGÃO, 2005).

De acordo com a matéria "O Mundo dos Congelados", do Jornal "Correio Brasiliense" (2002),

os consumidores da cidade de Brasília gostariam de consumir pratos prontos de 3 a 4 vezes por semana, mas a média é de 3 vezes por mês. A facilidade de preparo é o principal atrativo para decisão de compra. As classes A e B são os principais consumidores destes produtos e as vendas crescem nos finais de semana e nas férias escolares. Os principais produtos consumidos são Pizzas, Empanados, Tortas e Lasanha. 
O setor supermercadista percebeu o crescimento da venda de pratos congelados através dos resultados obtidos nas diversas lojas. Dados do setor mostram que $79,3 \%$ destes produtos são comprados em supermercados (GONÇALVES, 2000).

Em 2001, o povo brasileiro enfrentou uma grande crise de falta de energia elétrica, o que refletiu de forma negativa no consumo e comercialização de produtos congelados e refrigerados de forma geral (ABRAS, 2000). O setor de distribuição de energia elétrica é crítico no Brasil, agravando as condições de manutenção da cadeia do frio, tanto nos pontos de distribuição de alimentos atacadistas como nos varejistas de alimentos. É conhecido que um dos principais problemas verificados no comércio de alimentos pereciveis é a manutenção do cadeia do frio, levando a consideráveis perdas econômicas e possibilidade de desenvolvimento de microrganismos que possam ter sobrevivido ao processo industrial (esporulados) ou então por contaminação durante o transporte (ruptura de embalagens). Segundo a ABRAVA - Associação Brasileira de Refrigeração, Ar Condicionado, Ventilação e Aquecimento (2005), o setor supermercadista é um dos que vêm buscando eficiência energética como forma de ampliar sua produtividade, mas esse é um processo lento porque exige tecnologia e investimentos.

No ano de 2001, o Instituto de Defesa do Consumidor (IDEC) analisou as condições de armazenamento de alimentos congelados em supermercados da cidade de São Paulo, constatando uma inadequação na forma de expor os produtos industrializados (VIO, 2002). As principais irregularidades constatadas foram o excesso de produtos nos balcões, desrespeitando a linha de carga limite do balcão de congelados e temperaturas acima do recomendado pelo fabricante e pela legislação. Segundo o IDEC, o consumidor estava recebendo produtos com 
qualidade comprometida e com possibilidade de serem fontes de DTA (JORNAL DA TARDE, 2002).

No que se refere à segurança, os pratos semi-prontos e prontos congelados podem ser considerados alimentos de baixo risco para o consumidor já que a temperatura de armazenamento recomendada $\dot{e}-18^{\circ} \mathrm{C}$, conforme a Resolução $N^{\circ}$ 35 da CNNPA (BRASIL, 1977). Além disso, antes do consumo, o produto deve passar por um aquecimento a uma temperatura superior a $70^{\circ} \mathrm{C}$ (ANVISA, 2004).

As mudanças nos hábitos de consumo de alimentos continuaram mesmo após a era da comida congelada. Observa-se que a refeição fora do lar tem grande força em paises desenvolvidos como os EUA, com uma grande variedade e número de estabelecimentos de food service (lanchonetes, self-service) que oferecem refeições prontas. A concorrência entre os supermercados e esse estabelecimentos tornou-se acirrada, chamando a atenção da entidade americana FMI, que observou que os supermercados perdem aproximadamente 60 bilhōes de dólares/ano para as redes de fast food e restaurantes, que fornecem comida pronta para consumo no próprio estabelecimento ou em casa (ABRAS,1997).

Assim como o FMI, a ABRAS também verificou o crescimento da venda destes produtos prontos para o consumo no Brasil e a queda de venda de produtos "in natura" necessários para o preparo de refeições. Numa pesquisa realizada em conjunto, as duas entidades observaram que o país apresenta uma grande potencialidade de venda de comida pronta, em todas as classes sociais dos centros urbanos, inclusive nas mais baixas. Muitos trabalhadores, nos diversos setores da economia, recebem vales refeição e substituiram o velho hábito de levar a refeição em marmitas por serviços em praças de alimentação de "shopping centers" e outros 
restaurantes. A "comida por kilo" tornou atrativo o preço da refeição fora do lar (GAZETA MERCANTIL, 1999).

Inicialmente, a oferta de pratos prontos em supermercados acontecia principalmente em períodos de datas festivas, como Natal, Páscoa e outras, quando a tradição determina o consumo de alguns pratos típicos. Estes pratos típicos são preparações elaboradas e de alto valor agregado. A facilidade de ter tais preparações em supermercados, por um preço inferior ao dos restaurantes, é um atrativo para os consumidores (O GLOBO, 1999).

A compra de pratos prontos para o consumo em casa ou em lugares públicos tem diversas vantagens, conforme destacado em mátéria publicada no Jornal da Tarde, 2004:

[...] alternativa que permite variar o prato diariamente e deixar gastos com água, mão de obra, transporte e o principal: a facilidade de ser comprada no próprio supermercado.

Segundo a nutricionista consultora de restaurantes, padarias e supermercados, esta é a opção ideal para quem vive só ou para familias pequenas. Gasta-se menos e é possivel ter uma refeição variada e balanceada. A nutricionista coloca até razões sociais para o incremento na ampliação deste serviço, já que os consumidores dividem espaço nas mesas internas da loja. Há a oportunidade de se fazer novos relacionamentos.

Novos serviços estão sendo implantados como o "pastel de feira"e "caldo de cana" em quiosques em setores como o FLV (frutas, legumes e verduras) imitando o tradicional ambiente de rua. Este tipo de serviço é um verdadeiro sucesso em muitas lojas.

Alguns supermercados instalaram o serviço de self-service prâximo ao setor de padaria com um ambiente agradável para os consumidoresfazerem suas refeições [...]. 


\section{4 - QUALIDADE}

"ciência, em lugar

de empirismo; harmonia, em vez de discórdia; cooperação, não individualismo; rendimento máximo, em lugar de produção reduzida; desenvolvimento de cada homem, no sentido de alcançar maior eficiência e prosperidade" F.W.Taylor, 1987 apud Bellenzani, 2004

Dada a importância do tema "Qualidade" no cenário empresarial, torna-se importante definir seus principais conceitos (BELLENZANI, 2004). Segundo Campos (1992), um produto ou serviço com qualidade é aquele que atende perfeitamente as necessidades do cliente, de forma confiável, acessivel, segura e no tempo certo. Para Juran (1992, apud BELLENZANI, 2004), a qualidade está relacionada com a "adequação ao uso". Esta definição corresponde ao atendimento das necessidades dos clientes e ausência de defeitos.

De acordo com a ISO (International Organization for Standardization, 1994), qualidade é definida como "a totalidade do desempenho das características de um produto ou serviço, avaliadas de acordo com sua possibilidade efetiva, para atender às necessidades especificadas ou implícitas".

A qualidade em geral, e os atributos de segurança dos alimentos em particular, são importantes elementos para a tomada de decisão dos consumidores, para as estratégias privadas e para as políticas públicas (SPERS, 2003). Garantir a qualidade dos alimentos é um crescente foco dos governos, indústrias e agentes de padronização e comércio internacional. Seus esforços são direcionados a influenciar 
os muitos atributos de um produto alimentar, com um cuidado particular em relação ao aspecto nutricional e segurança, ou seja, a inocuidade do alimento.

Os órgãos de Saúde, tanto no âmbito Federal quanto Estadual (São Paulo), possuem Programa de Monitoramento da Qualidade de Alimentos. Tais programas fundamentam-se no controle e fiscalização de alimentos, para verificar a conformidade dos produtos com os padrões sanitários baseados em legislações vigentes. A ANVISA coordena O Programa Nacional de Monitoramento da Qualidade Sanitária de Alimentos - PNMQSA (ANVISA, 2003)

O Programa de Análise Fiscal de Alimentos - Programa Paulista, gerenciado pelo Centro de Vigilância Sanitária de São Paulo (CVS/SP), além de monitorar a qualidade sanitária de produtos alimentícios, busca detectar irregularidades nos estabelecimentos responsáveis por sua comercialização ou fabricação através da aplicação da legislação sanitária vigente (CVE, 2002).

Segundo Lopes (2005, apud PAULA, 2005), qualidade em alimentos possui dimensão crescente. Deve incluir itens como preço, responsabilidade social, segurança ambiental, segurança e saúde do trabalhador, atender exigências legais (como padrão de identidade e qualidade de produtos), atributos sensoriais (como sabor, cor, textura e etc) e o mais importante - a saúde e integridade do consumidor.

O consumidor percebe a existência de determinado padrão de qualidade pela combinação de diferentes atributos. Porém, a grande maioria de consumidores brasileiros ainda opta por um produto ou serviço em função de seu preço. Esse comportamento será tratado mais detalhadamente no item 2.7 , referente à descrição de consumidor. 


\section{5- SEGURANÇA ALIMENTAR E SEGURANÇA DOS ALIMENTOS NO BRASIL}

O conceito de Segurança Alimentar adotado pelo Brasil conforme a Portaria n 710 que Aprova a Política Nacional de Alimentação e Nutrição, é:

Segurança Alimentar significa o acesso universal aos alimentos, o aspecto nutricional e, conseqüentemente, as questões relativas à composição, à qualidade e ao aproveitamento biológico.

Para atender o propósito desta Política, definiu-se diretrizes básicas para a garantia da segurança e da qualidade dos alimentos e para a prestação de serviços neste contexto, onde o valor nutricional e os critérios de qualidade sanitária dos alimentos devem ser fortalecidos por ações da vigilância sanitária, preservando assim a saúde do consumidor (BRASIL, 1999).

Durante a I Conferência Municipal de Segurança Alimentar de São Paulo (2001), muito se debateu sobre a amplitude do conceito de Segurança Alimentar. O consenso a que se chegou foi:

\footnotetext{
Segurança alimentar significa tornar disponiveis aos cidadãos alimentos seguros e de qualidade, que satisfaçam suas necessidades nutricionais, seus hábitos e práticas alimentares culturalmente construídos e que promovam uma vida ativa e saudável.
}

Portanto, é importante conceituar adequadamente os termos "Segurança Alimentar", "Segurança do Alimento" e "Alimento Seguro". De acordo com SPERS (2003), segurança alimentar tem um enfoque quantitativo e refere-se ao abastecimento adequado de uma determinada população, enquanto segurança do alimento e alimento seguro têm um enfoque qualitativo; estão relacionados à garantia do consumidor em adquirir alimentos com atributos de qualidade que sejam do seu interesse, inclusive aqueles ligados à saúde. 


\section{A SEGURANÇA DOS ALIMENTOS COMO ATRIBUTO DA QUALIDADE}

Até o início da década de 80 , o controle da qualidade de alimentos era feito com base na análise do produto, através de amostragem de lotes do produto final. Esse controle tinha um caráter reativo, isto é, "produto bom" é aceito e o "produto ruim" é rejeitado. Um dos procedimentos utilizados para aceitar ou rejeitar um alimento é a análise microbiológica.

Análises microbiológicas no produto final têm muitas limitações quanto ao seu poder de informar se um alimento é seguro ou não. Além de onerosas e destrutivas, só têm significado quando é analisado um grande número de amostras por lote. Lopes (2002), afirma que:

\footnotetext{
"Utilizando um plano de amostragem conforme recomendado pelo ICMSF - International Commission on Microbiological Specifications for Foods para o pior caso (caso 15), seria necessário analisar 60 amostras por lote. Admitindo-se uma freqüência de Salmonella da ordem de 1 amostra positiva para cada 1.000 amostras (razão de defeito-0,1\%) ainda assim haveria uma probabilidade superior a $94 \%$ de se aceitar lotes que deveriam ser rejeitados."
}

Diante das evidências de que este tipo de controle não é viável, as empresas alimenticias passaram a adotar um procedimento preventivo no que diz respeito ao controle de qualidade. Para se ter produtos controlados é necessário agir já na seleção de matérias primas e durante todo o processo produtivo.

Numa era de economia global, não é possível garantir a sobrevivência das empresas apenas exigindo que funcionários façam o melhor que puderem ou cobrando apenas resultados. Atualmente, são necessários métodos que possam ser utilizados por todos em direção aos objetivos de sobrevivência da empresa. Estes métodos devem ser aprendidos e praticados por todos. Este é o princípio da abordagem gestão da qualidade total (CAMPOS,1992). 
A gestão da qualidade torna-se importante na medida em que existem custos, embora não facilmente mensuráveis, mas que afetam diretamente a rentabilidade das empresas de alimentos. Entre os prejuízos ocasionados por contaminações, estão a perda do produto, os custos de ações legais e indenizações dos consumidores e o desgaste da imagem da empresa e/ou da marca do produto.

Campos (1992) destaca que o Controle Total da Qualidade é regido por 10 princípios básicos:

1. Produzir e fornecer produtos e/ou serviços que atendam concretamente às necessidades dos clientes (produtos e serviços em sua maioria são para satisfazer a necessidade humana)

2. Garantir a sobrevivência da empresa através do lucro contínuo adquirido pelo domínio da qualidade (quanto maior a qualidade maior a produtividade);

3. Identificar o problema mais crítico e solucioná-lo pela mais alta prioridade;

4. Falar, racionalizar e decidir com dados e com base em fatos;

5. Gerenciar a empresa ao longo do processo e não por resultados (quando o resultado negativo aparece, a ação é tardia) - o gerenciamento deve ser preventivo;

6. O cliente é o "rei". Não permitir a venda de produtos defeituosos;

7. Procurar trabalhar de forma a prevenir problemas;

8. Nunca permitir que o mesmo problema se repita pela mesma causa;

9. Respeitar os empregados como seres humanos independentes;

10. Definir e garantir a execução da Visão e Estratégia da Alta Direção da empresa. 


\section{6- SISTEMAS DE GESTÃO DA QUALIDADE E SEGURANÇA DOS ALIMENTOS}

Sistemas de gestão da qualidade não podem ser estáticos, mas dinâmicos. Através do Ciclo PDCA ${ }^{1}$, as empresas podem rever seus programas de qualidade para melhoria contínua e o reconhecimento de excelência no mercado.

Bellenzani (2004) afirma que as empresas de alimentos devem ter um sistema de qualidade organizado, baseado em um conjunto de normas que contemplem atitudes adequadas dos colaboradores, métodos, processos e informações, que assegurem eficazmente a qualidade em condições econômicas favoráveis para os consumidores e para a empresa. Nesse sentido, deve haver a integração entre as normas ISO, as Boas Práticas de Fabricação (BPF) e a Análise de Perigos e Pontos Críticos de Controle (APPCC).

As Boas Práticas e o Sistema APPCC são ferramentas referendadas pela legislação, que visam a segurança e a qualidade dos alimentos (OPAS, 2001)

As Boas Práticas são pré-requisitos para a implantação do Sistema APPCC, e constituem-se em um conjunto de procedimentos voltados para minimizar os riscos de contaminação dos alimentos. As Boas Práticas e o Sistema APPCC são recomendados por organismos internacionais, como a Organização Mundial do Comércio (OMC), a Organização das Nações Unidas para Alimentação e Agricultura (FAO) e a Organização Mundial da Saúde (OMS).

A figura 1 apresenta a estrutura do sistema da qualidade para empresas produtoras de alimentos e bebidas em forma de pirâmide, mostrando que conceitos ligados à segurança e inocuidade de alimentos estão na base e devem ser ponto de

\footnotetext{
${ }^{1}$ Ciclo PDCA $\rightarrow$ P- planejar e documentar; D- implementar; C- monitorar ou controlar e A - agir corretivamente
} 
partida para as empresas de alimentos que desejam reconhecimento na busca da excelência de seus produtos e serviços.

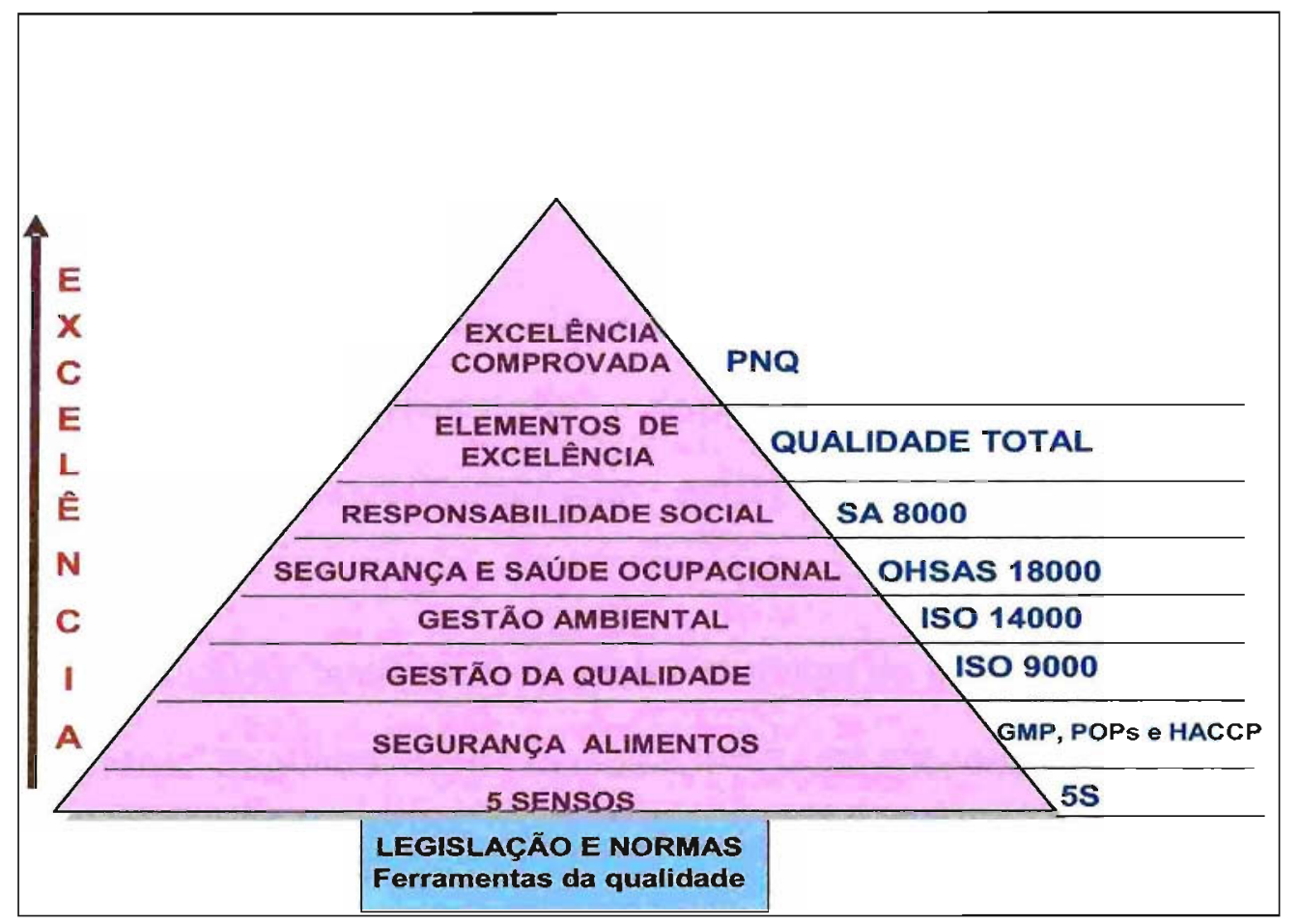

Figura 1: Estrutura do sistema da qualidade para alimentos e bebidas Fonte: LOPES, 2004

Legenda:

5 S- Deriva de 5 palavras japonesas SEIRI (arrumação), SEITON (ordenação), SEISOH ( limpeza), SEIKETSU (asseio), SHITSUKE (auto-disciplina)

PNQ- Prêmio Nacional de Qualidade

SA 8000- Norma da Social Accountability International

OHSAS 18000- Norma da Occupational Health Safety Assessment Series ISO 9000- Norma Técnica da International Organization for Standardization relativa a Gestão da Qualidade

ISO 14000- Norma Técnica da International Organization for Standardization relativa a Gestão Ambiental

GMP- Good Manufacturing Practices

POPs- Procedimento Operacional Padronizado

HACCP- Hazard Analysis and Critical Control Points 
A cadeia produtiva de alimentos é formada por vários elos, que vão desde a produção primária até o consumidor. Todos os elos devem ter participação na manutenção da qualidade e segurança dos alimentos, adotando normas (critérios) compativeis que devem ser cumpridas (APAS, 2005).

O setor varejista é parte integrante da cadeia de alimentos. Se não forem adotadas normas nessa etapa, ela poderá ser muito crítica e contribuir para ocorrência de surtos de doenças de origem alimentar (SENAC/SESC/SESI/ANVISA/SEBRAE, 2004). Este é o elo mais próximo do consumidor.

O consumidor também deve adotar condutas de segurança na manipulação de alimentos. Segundo os dados da OPAS, $36,8 \%$ dos casos de doenças transmitidas por alimentos acontecem nas residências (OPAS, 2001). 


\section{7- CONSUMIDOR}

"O consumidor é Rei"

Blackwell, Miniard e Engell

Segundo Fukuma (SEMINÁRIO DE SEGURANÇA DOS ALIMENTOS DA APAS, 2005), o consumo rege o mundo. Crianças, adolescentes, adultos e idosos, independentemente da classe social a que pertençam, são consumidores. Consumir não significa apenas comprar, mas também usar e descartar corretamente.

Antes da compra, o consumidor tem expectativas sobre o desempenho do produto ou serviço, e a satisfação desse consumidor é o resultado esperado. Satisfação é definida como a avaliação pós-consumo de que o produto ou serviço escolhido pelo consumidor atende ou supera as expectativas (ENGEL, BLACKWELL, e MIINARD, 2005). Para se comprar um produto ou serviço, é preciso haver o reconhecimento de necessidade do produto ou serviço (VICTALINO, 2004).

Num mercado altamente competitivo, as empresas devem estar com o seu foco orientado para seus consumidores. Para tanto, devem levar em consideração as necessidades presentes e futuras de seus consumidores.

Blackwell, Miniard e Engel (2005) descrevem que o processo de decisão do consumidor é baseado em necessidades ou no desejo de produtos e serviços. A figura 2 mostra como é o processo de decisão de compra do consumidor. 


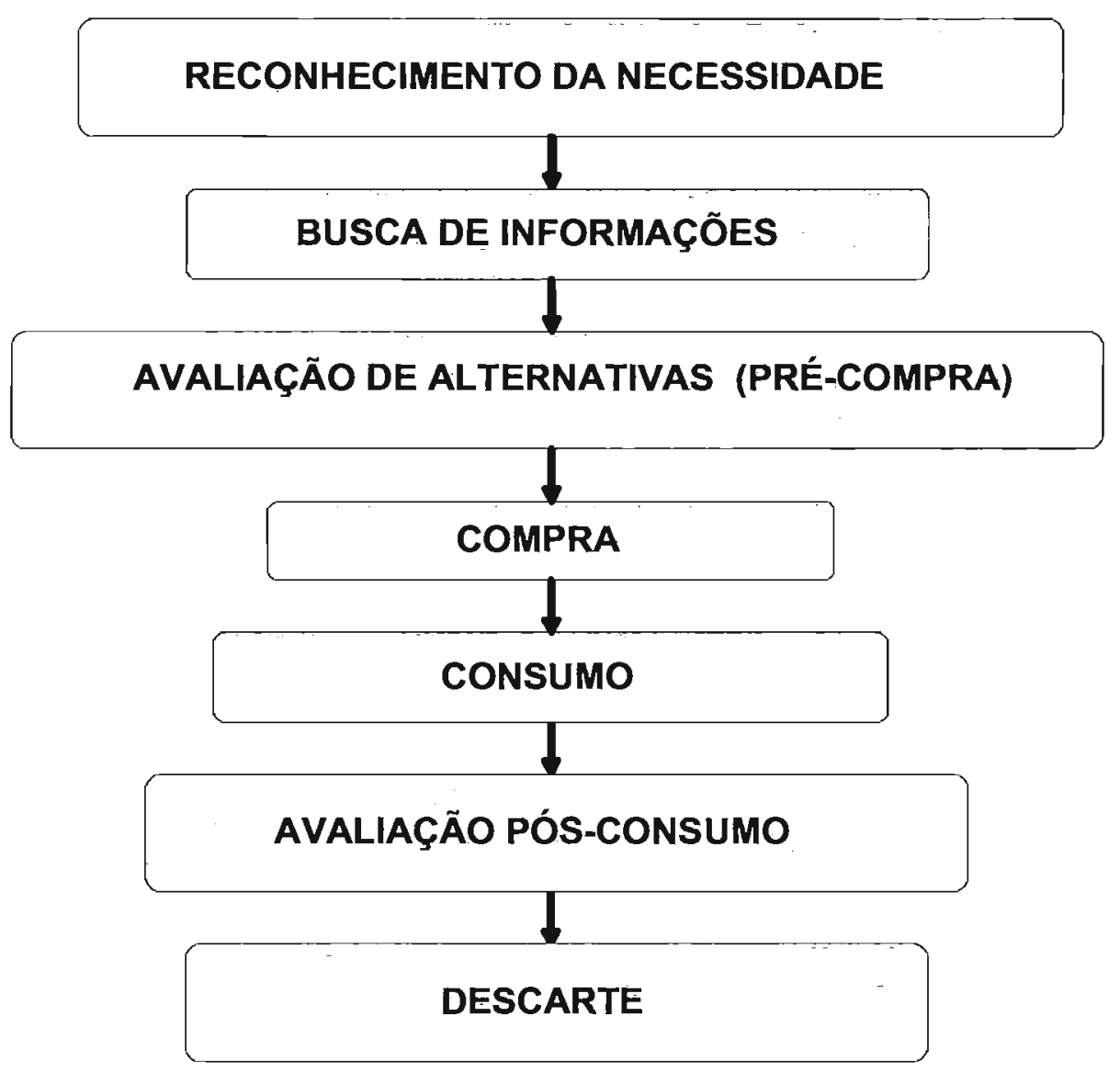

Figura 2: Como consumidores tomam decisões para bens e serviços Fonte Blackwell, Miniard e Engel, 2005

No aspecto legal, a Lei $N^{\circ} 8.078$ (Código de Defesa do Consumidor) define que consumidor é toda pessoa física ou jurídica que adquire ou utiliza produto ou serviço como destinatário final. Dentre os direitos básicos do consumidor, estão inclusos:

"A proteção da vida, saúde e segurança contra os riscos provocados por práticas no fornecimento de produtos e serviços considerados perigosos ou nocivos." 
Ainda em referência ao Código de Defesa do Consumidor, existem outros artigos que são do interesse desta dissertação, como as informações extraídas dos artigos- 6 ao 27 , onde há referência à Proteção à Saúde e Segurança

"Os produtos e serviços colocados no mercado de consumo não acarretarão riscos à saúde ou segurança dos consumidores."

e também aos Vícios da Qualidade por insegurança citados pela Associação Brasileira de Engenheiros de Alimentos (2003):

"na ingestão de alimentos contaminados por bactéria patogênica ou pelas toxinas destas, levando o consumidor a ter sintomas que variam desde intoxicações brandas (diarréias, vômitos, dores de cabeça) até infecções graves (apresentando complicações que exigem sua hospitalização, podendo levá-lo à morte). Cada um destes casos é considerado pelo Código de Defesa do Consumidor um Acidente de Consumo e o consumidor tem o direito de ser indenizado pelos danos morais e/ou patrimoniais (gastos médicos hospitalares, medicamentos etc.) eventualmente sofridos."

Para Fukuma (SEMINÁRIO DE SEGURANÇA DOS ALIMENTOS DA APAS, 2005), algumas reivindicações dos consumidores de alimentos são:

- ampliação da cobertura de inspeção sanitária, atingindo todas as regiões do pais

- rastreabilidade dos produtos de origem animal e vegetal

- criação de sistema que permita à população receber maiores informações sobre as ações de fiscalização, apreensões, interdições e proibições de comercializações de produtos alimentícios que possam colocar em risco à saúde humana. 


\subsection{1 - MUDANÇAS NO COMPORTAMENTO DO CONSUMIDOR EM RELAÇÃO A} ALIMENTOS

Os hábitos alimentares das pessoas podem variar em função de seu estilo de vida, poder aquisitivo, formação e crenças, dentre outros fatores. Segundo Carvalho (2005), o setor de varejo de alimentos tem aproveitado bem as mudanças sociais do país, sua relação com os hábitos alimentares e o crescente número de pessoas que fazem refeições fora do lar.

Além das mudanças sócio-econômicas do país, uma das mudanças mais fortes está relacionada à familia e ao papel da mulher na sociedade. A familia tradicional, na qual o homem era o principal provedor do sustento e a mulher ocupava o lugar de esposa, mãe e principal responsável pelas tarefas domésticas, incluindo o preparo de refeições, mudou completamente. A esposa que cuidava de todas as tarefas domésticas deu lugar a uma mulher que está assumindo um papel cada vez mais ativo na economia. Com uma jornada de trabalho fora do lar intensa, a mulher procura facilitar a rotina doméstica buscando opções de alimentos prontos ou semi-prontos para a família.

Além disto, há um número crescente de pessoas que moram sozinhas, preferindo a facilidade de alimentos prontos ou semi-prontos que permitam uma refeição rápida, condizente com o seu estilo de vida.

Há também aquelas pessoas que não gostam ou não querem se envolver com "a arte culinária" e com tarefas domésticas, como preparar alimentos. Esse público vê na refeição preparada fora do lar diversas vantagens: cardápio variado, nenhum trabalho de preparação e total liberdade de horário para fazer as refeições. Segundo Parente (2000), outra mudança que ocorre no mercado consumidor brasileiro é o aumento do poder de consumo nas cidades do "interior", a 
importância econômica de regiões como o Nordeste e a participação de indivíduos da terceira idade. Além disto, os consumidores prestam mais atenção à saúde, à alimentação e ao condicionamento físico.

A "busca da conveniência" e a "falta de tempo" são características marcantes que vêm moldando o comportamento e os hábitos de compra. Os supermercadistas vêm procurando ajustar-se à necessidade e às novas expectativas do consumidor oferecendo maior agilidade no atendimento e nos caixas, uma departamentalização melhor sinalizada para facilitar o processo de compra e serviços que agregam conveniência, como funcionamento durante 24 horas, entregas em domicílio e disponibilização de alimentos prontos para o consumo (BLACKWELL, MINIARD e ENGEL, 2005).

Para Lampert (1997), as empresas que não compreenderem as expectativas e necessidades de seus consumidores não evoluirão no seu negócio. Estar sintonizado e acompanhando as mudanças de hábitos de compra do consumidor é um requisito básico para os negócios das empresas e as informações sobre os consumidores devem ser baseadas em pesquisas de comportamento do consumidor.

\subsection{2 - PESQUISAS SOBRE HÁBITOS E PERCEPÇÃO DOS CONSUMIDORES}

Apesar de ser um tema de extrema importância para estratégias de marketing das empresas que compõe o elo da cadeia de abastecimento, poucas pesquisas são realizadas sobre a percepção do consumidor brasileiro quanto à qualidade dos produtos alimentícios vendidos em supermercados. 
Em um estudo realizado em 1997, o PROVAR (Programa de Administração de Varejo), a FIA (Fundação Instituto de Administração) e a FEA (Faculdade de Economia e Administração) da USP examinaram hábitos de compra de consumidores de supermercados em São Paulo (Capital), enfatizando as mudanças ocorridas com a estabilização econômica. A pesquisa, intitulada "Hábitos de Compra nos Supermercados Paulistanos", apresentou os seguintes objetivos:

- Ser um instrumento prático para os proprietários e executivos do setor supermercadista inclusive fornecedores;

- Identificar áreas estratégicas a serem contempladas na gestão do negócio;

- Retratar a percepção que consumidores têm dos supermercados quanto à aspectos especificos

As conclusões do estudo foram:

o supermercado é o principal local de compra para abastecimento do domicílio;

ter "preços baixos" ainda é o principal critério de escolha do supermercado tanto para as pequenas compras (reposição) como para as grandes (abastecimento);

os atributos mais importantes na escolha do supermercado foram: "ter preços baixos" (97,8\%), "ter preocupações com a limpeza" $(96,8 \%)$ e "rapidez no caixa/pouca fila" $(96,5 \%)$; 
o grau de importância dos atributos no supermercado variou com a classe social. Apesar de em todas as classes o atributo mais importante na escolha de um supermercado ter sido o "preço baixo", a preocupação com "as condições de limpeza" foi maior na classe $A$;

para a classe A, o item mais importante para rejeição de um supermercado foi "más condições de limpeza" (46\%). Para a classe B, outros itens, como "proximidade da residência", foram mais importantes e o item "más condições de limpeza" não foi mencionado. No entanto, para a classe C esta resposta apareceu apenas como quinta opção $(3,9 \%)$;

o grau de confiabilidade quanto à qualidade dos alimentos vendidos em supermercados, que no estudo do PROVAR foi denominado de "Segurança quanto à Qualidade dos Produtos", obteve as seguintes respostas dos consumidores entrevistados: muito seguro $13 \%$, seguro $51 \%$, indiferente ("nem seguro", "nem inseguro") 9\%. Os consumidores mostraram-se mais preocupados com a "operação e manuseio" dos alimentos (questões ligadas ao supermercado) do que com sua composição (questões ligadas ao fabricante);

quando perguntados sobre a "Principal Ameaça à Qualidade dos Alimentos Vendidos em Supermercados", os consumidores responderam: contaminação com bactérias - $29,2 \%$, estragar devido à refrigeração inadequada $-23,6 \%$, presença de insetos e ratos - $17,2 \%$, manuseio 
inadequado - $12,4 \%$, falta de frescor dos produtos - 9,8\% e presença de produtos químicos (corantes e conservantes) $-7,8 \%$.

A pesquisa incluiu ainda uma análise dos hábitos de compra na seção de "Rotisseria". Na época do estudo (1997), apenas 15,5\% dos entrevistados admitiram consumir alimentos prontos para consumo nessa seção. A faixa etária predominante desses consumidores estava entre 25 e 34 anos, declinando a partir dos 55 anos. Na época do estudo, a maioria dos entrevistados (57\%) admitiu comprar alimentos prontos em "fast-foods" e pizzarias, seguido de outros restaurantes self service $(27,7) \%$. As padarias também foram apontadas como locais de compra de refeições prontas $(15,3 \%)$.

Outra pesquisa foi realizada em 1999 pela Associação Brasileira de Supermercados (ABRAS), em parceria com o Food Marketing Institute (FMI) e a Associação Latino-americana de Supermercados (ALAS), e foi intitulada "Tendências no Brasil - Atitudes/Comportamento do Consumidor e o Supermercado". O estudo, tal como o do PROVAR, teve o objetivo de fornecer ao empresário supermercadista um panorama sobre hábitos de compra dos consumidores, informações que consideram importante para escolher um estabelecimento e como os consumidores vêem a atuação da loja onde realizam suas compras. Os principais tópicos deste estudo foram: os padrões de compra, a lealdade à loja e razões para mudança, expectativas e atuação da loja, atitudes do consumidor em relação à nutrição e segurança (enfoque qualitativo) dos produtos.

A pesquisa foi realizada com 800 consumidores das cidades de São Paulo, Rio de Janeiro, Salvador, Recife, Porto Alegre, Belém, Brasília e Belo Horizonte. Estes consumidores em sua maioria eram mulheres, pertenciam a classes sociais de 
A à D, tinham idade entre 18 e 49 anos e eram os principais responsáveis pela aquisição de alimentos da familia.

Os resultados mostraram que os consumidores brasileiros estão bastante preocupados com questões econômicas. Reforçando a conclusão do estudo do PROVAR, o estudo comprovou que o supermercado é o local mais apontado como loja primária, isto é, aquela onde os consumidores compram com mais freqüência. Apenas um em cada quatro dos entrevistados respondeu que compra alguns tipos de alimentos em lojas especializadas, como açougue (carnes), padaria (pão e leite), peixaria (peixes e frutos do mar) e outras. Produtos perecíveis, como carnes, laticinios, frutas e verduras são adquiridos nos supermercados com maior freqüência do que outros produtos, levando os consumidores às lojas pelo menos uma vez, ou mais, por semana. No período de realização do estudo, apenas $32 \%$ dos consumidores responderam que suas lojas primárias ofereciam também comida pronta em rotisserias.

Quando perguntados sobre a confiança na segurança dos alimentos (enfoque qualitativo), a maioria dos consumidores (61\%) respondeu que confiava na segurança dos alimentos quando comprados na loja primária. Os menos confiantes foram os consumidores que compram em mercadinhos ou lojas de conveniência. Perguntados sobre a principal ameaça para a qualidade de um alimento e se isto poderia representar uma ameaça à saúde, a maioria dos consumidores $(57 \%)$ respondeu que a principal ameaça estava relacionada à data de validade do produto alimenticio (FMI; ALAS; ABRAS, 1999).

Os consumidores americanos buscam conveniência tal como os consumidores brasileiros. Porém, os consumidores americanos podem apresentar 
critérios diferentes dos consumidores brasileiros no momento de escolha do supermercado onde realizam suas compras. Segundo Engell (2005), em uma pesquisa realizada com consurridores americanos e canadenses, os americanos apontaram a limpeza como a primeira razão para selecionar um supermercado, enquanto que os consumidores canadenses responderam que ter um "bom departamento de hortifrutigranjeiros" é a primeira razão de escolha. O autor completa que a preocupação dos americanos com limpeza é compreensível já que nos EUA práticas não higiênicas nas seções de carnes em supermercados são comuns.

Quanto à responsabilidade pela segurança dos alimentos, um estudo do FMI (FMI FOOD SAFETY, 2004) verificou que 32\% dos consumidores americanos consideraram que a segurança (inocuidade) dos alimentos era sua responsabilidade, $21 \%$ responderam ser responsabilidade do governo, $15 \%$ disseram que a responsabilidade era da indústria de alimentos, $14 \%$ das lojas de alimentos (varejistas), $7 \%$ dos grupos de proteção de consumidores e $3 \%$ dos fazendeiros.

A educação e informação são de extrema importância para ajudar a diminuir os números de casos de doenças transmitidas por alimentos na população. Segundo Parente (2000), o grau de educação é uma das dimensões que influenciam o comportamento do consumidor. Em geral, pessoas que recebem educação básica são mais bem informadas e mostram maior grau de exigência na qualidade de produtos.

Nos EUA, os consumidores contam com programas de educação e esclarecimento sobre a manipulação higiênica de alimentos e prevenção de DTA, tais como o Programa FIGHTBAC, desenvolvido pelo governo americano em 
parceria com organizações não governamentais e associações de classe, como o FMI. Através de diversos tipos de mídia, a população recebe instruções sobre Boas Práticas de Manipulação e formas de prevenção de doenças transmitidas por alimentos (FMI, 2004).

Como conseqüência, os consumidores americanos estão cada vez mais conscientes que devem adotar normas de segurança e boas práticas de manipulação de alimentos em casa ao preparar refeições. A porcentagem de americanos que manifestaram a adoção de práticas de higiene na manipulação de alimentos em casa para prevenir DTAs passou de $32 \%$ em 2000 para $42 \%$ em 2004. Os consumidores responderam que adotaram práticas como a lavagem de mãos toda vez que manipulam alimentos (89\%), lavagem prévia dos hortifruti (88\%), controle de pragas nas residências $(88 \%)$, refrigeração imediata dos alimentos após o preparo (85\%), dentre outras respostas (FMI, 2004). 


\section{8 - SUPERMERCADOS}

\subsection{1 - DEFINIÇÕES, LEGISLAÇÃO E LAYOUT}

"Passado vitorioso, futuro promissor" Antonio Carlos Ascar ${ }^{2}$

Desde sua implantação no Brasil, há cinqüenta anos, os supermercados têm desempenhado um papel fundamental no abastecimento da população brasileira. As primeiras experiências de auto-serviço no comércio varejista vieram junto com as primeiras empresas americanas estabelecidas no Brasil. Alguns hábitos foram adotados devido a admiração do "american way of life" , que representava uma forma diferente de comprar e vender. Nessa época, o modelo brasileiro de compra de alimentos era em estabelecimentos como armazéns, empórios e mercearias nos quais era comum o uso de um sistema rudimentar de crédito, a caderneta. O comércio também era realizado em açougues, ou por vendedores ambulantes, como peixeiros, verdureiros e leiteiros (RODRGUES, 1993).

De acordo com Rodrigues (1993), o auto-serviço foi primeiramente utilizado por volta dos anos 50, em uma loja em São Paulo que pertencia ao Frigorífico Wilson - empresa de origem americana. A loja unia o setor de carnes, servido por açougueiros, ao de mercearia, montado como auto-serviço. Dentro da loja, os clientes contavam com cestinhas de vime para carregar os produtos escolhidos durante as compras. O auto-serviço é definido como método de venda no qual as mercadorias são expostas de modo a permitir que o comprador pegue aquelas que

\footnotetext{
${ }^{2}$ Diretor de Desenvolvimento do Grupo Pão de Açúcar - Companhia Brasileira de Distribuição
} 
The são mais convenientes, sem o auxílio de intermediários, e pague à saída do estabelecimento.

Empresários brasileiros que resolveram seguir este modelo de empresa importaram dos Estados Unidos novas idéias de procedimentos necessários para implantação de supermercados. As novidades exigiram imensos esforços, como a aquisição de equipamentos especiais ainda não fabricados no país, como o balcão frigorífico aberto para a venda de cortes especiais de carne.

Segundo Cyrillo (1987), desde o início o governo brasileiro tinha simpatia pelos supermercados, devido à sua importância para o abastecimento de alimentos. O novo sistema de distribuição poderia ser a solução para o problema do abastecimento urbano. Esta aceitação, na realidade, constituiu-se no primeiro passo para a consolidação dos supermercados no Brasil.

Supermercados são estabelecimentos varejistas. Segundo Parente (2000 a):

varejo consiste em todas as atividades que englobam o processo de venda de produtos e serviços para atender a uma necessidade pessoal do consumidor final. $\mathrm{O}$ varejista faz parte dos sistemas de distribuição entre $\mathrm{O}$ produtor e o consumidor, desempenhando um papel intermediário, funcionando como um elo de ligação entre o nível do consumo e o nível do atacado ou da produção" .

A figura 3 ilustra o canal de distribuição de nível três, onde há uma fase intermediária entre o produtor e o consumidor. 


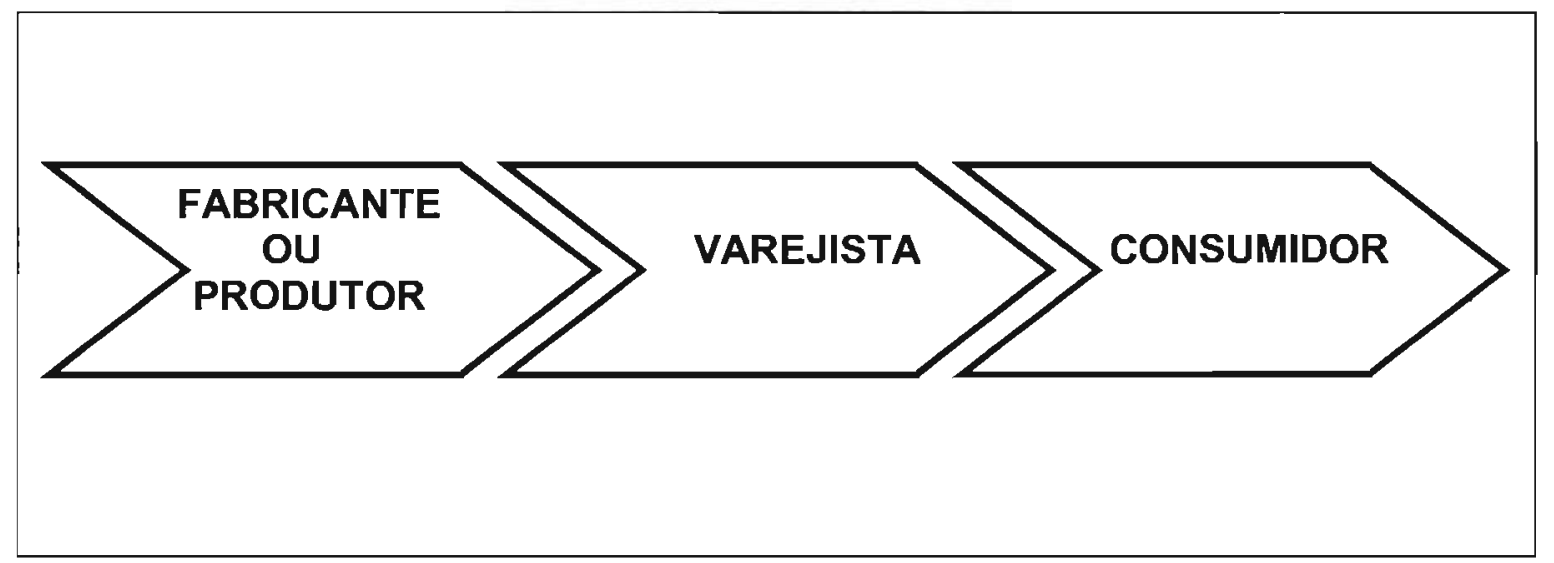

Figura 3: Esquema de canal de distribuição para bens de consumo

FONTE: adaptado de PARENTE (2000 b)

Segundo Aurélio (1995), a definição clássica de supermercados é a seguinte: são estabelecimentos comerciais onde se expõe à venda grande variedade de mercadorias, em particular gêneros alimentícios, bebidas, produtos de higiene e limpeza doméstica.

Todo e qualquer estabelecimento comercial de alimentos deve seguir as normas estabelecidas pelos orgãos competentes, que têm o intuito de proteger o público não somente contra danos à saúde, mas também contra fraudes e enganos (DALLARI, 2000; MARQUES 2002).

Germano (2003) afirma que, há vários séculos, os governantes têm o papel de cuidar da qualidade higiênico-sanitária dos produtos alimentícios, emitindo sanções para aqueles que comercializam alimentos adulterados ou deteriorados e que não atendem as especificações previstas.

No Brasil, a legislação aplicada à questão higiênico-sanitária para o setor de comércio varejista de alimentos é de competência do Ministério da Saúde e de suas agências nos Estados e Municípios. Entretanto, verifica-se que no Brasil há 
orgãos e entidades atuando sobre o mesmo assunto nas Pastas da Saúde e da Agricultura. Além disso, as secretarias representativas nos Estados e Municípios também têm normas sobre a comercialização de alimentos (DIAS, 2002).

No âmbito do Estado de São Paulo, a legislação sanitária relativa a supermercados está no Código Sanitário, e determina que:

Supermercados e congêneres terão área minima de $400 \mathrm{~m}^{2}$ com dimensão minima de $10 \mathrm{~m}$; seus locais de venda obedecerão as exigências técnicas previstas neste regulamento, segundo o gênero de comércio, no que lhes forem aplicáveis, dispensados os requisitos de área mínimas.

No âmbito do Municipio de São Paulo, os supermercados e congêneres devem seguir as determinações do Código Sanitário Municipal - Lei Nº 13.725 (SÃO PAULO, 2004), que em seu Art. 44 define esses locais como sendo:

"estabelecimento que comercializa produtos e substâncias de interesse da saúde (alimentos, água mineral, bebidas de consumo humano, cosméticos, perfumes, produtos de higiene, saneantes, domissanitários, agrotóxicos e embalagens ou outros produtos que possam trazer riscos à saúde".

O Art. 46 desta mesma Lei determina que

"Os estabelecimentos industriais, comerciais e de prestação de serviços relacionados aos produtos e substâncias de interesse da saúde são responsáveis pela manutenção dos padrões de identidade, qualidade e segurança, definidos a partir de normas técnicas, aprovadas pelo órgão competente, bem como pelo cumprimento de normas de boas práticas de fabricação e de normas de boas práticas de prestação de serviços.

$\S 1^{\circ}$ - Os estabelecimentos referidos no "caput" deste artigo, sempre que solicitados pela autoridade sanitária, devem apresentar o fluxograma de produção e os documentos e instrumentos que expressem o cumprimento das normas de boas práticas de fabricação e de prestação de serviços.

$\S 2^{\circ}$ - Deve ser assegurado ao trabalhador o acesso aos documentos e instrumentos que expressem o cumprimento de normas de boas práticas de fabricação e de normas de boas práticas de prestação de serviços." 
Ainda no âmbito Municipal, a Portaria 2.536/03-SMS.G (SÃO PAULO, 2003) traz a definição das principais atividades e caracteristicas do comércio varejista de alimentos em consonância com o Código Nacional de Atividades Econômicas CNAE:

Supermercado: estabelecimento com área de venda entre 300 a 5000 metros quadrados, destinado à comercialização de produtos alimentícios e de outras mercadorias

Hipermercardo: estabelecimento, com área de venda superior a 5000 metros quadrados, destinado à comercialização de produtos alimentícios e de outras mercadorias, incluindo o comércio varejista de carnes, pescados, produtos de panificação e confeitaria

De acordo com o Decreto 42.740 (SÃO PAULO, 2002), as empresas de produtos de interesse à saúde devem ter o Cadastro Municipal de Vigilância Sanitária (CMVS), que substitui a licença de funcionamento como também a caderneta sanitária. O Cadastro Municipal de Vigilância Sanitária é integrado ao Cadastro Estadual de Vigilância Sanitária - CEVS. Antes de iniciarem suas atividades, as empresas de alimentos devem requerer o cadastro e a inspeção sanitária inicial do estabelecimento.

Em 24 de outubro de 2003, foi publicada a Portaria 2. 535/03-SMS.G - da Secretaria Municipal de Saúde de São Paulo, "Regulamento Técnico para o Controle Higiênico-Sanitário em Empresas de Alimentos". Esta Portaria aplica-se a todas as empresas nas quais sejam realizadas algumas das seguintes atividades: produção/fabricação, importação, manipulação, fracionamento, armazenamento, distribuição, venda para o consumo final e transporte de produtos na área de alimentos. 
Os objetivos deste regulamento são subsidiar as ações da Vigilância Sanitária, estabelecendo critérios de higiene, adoção das Boas Práticas de Fabricação (BPF) e Prestação de Serviço e os Procedimentos Operacionais Padronizados em Empresas de Alimentos, visando prevenir e proteger a saúde do consumidor, a saúde do trabalhador e, ainda, preservar o meio ambiente.

Além disto, a Portaria 2.535/03 SMS.G determina a presença de Responsável Técnico, que deve auxiliar na implantação e implementação da política de qualidade assegurada da empresa e ser responsável pelo treinamento dos funcionários e pela elaboração, atualização e implantação do Manual de Boas Práticas de Fabricação/Prestação de Serviços. Este manual deve ser individual e específico para a realidade do estabelecimento.

Quanto ao layout, os supermercados caracterizam-se pelo sistema autoserviço, check-outs (caixa registradora sobre balcão na saída da loja) e produtos dispostos de maneira acessivel, que permitem aos clientes "auto-servirem-se", utilizando cestas e carrinhos (PARENTE, 2000).

Por haver uma enorme variedade de tipos de estabelecimentos varejistas de alimentos, a ABRAS adota a classificação descrita na Tabela 1. 
Tabela 1: Classificação dos Estabelecimentos Varejistas de Alimentos, segundo ABRAS (Associação Brasileira de Supermercados)

\begin{tabular}{|l|l|l|l|l|}
\hline $\begin{array}{l}\text { Formato de } \\
\text { lojas }\end{array}$ & $\begin{array}{l}\text { Área de } \\
\text { vendas } \mathrm{m}^{2}\end{array}$ & $\begin{array}{l}\text { Número } \\
\text { médio de } \\
\text { ítens }\end{array}$ & $\begin{array}{l}\text { Número de } \\
\text { check-outs }\end{array}$ & Seções \\
\hline Mercearias & $20-50$ & 500 & Não tem & $\begin{array}{l}\text { Mercearia, frios e } \\
\text { laticinios }\end{array}$ \\
\hline Minimercado & $50-100$ & 1.000 & 1 & $\begin{array}{l}\text { Mercearia, frios e } \\
\text { laticinios, bazar }\end{array}$ \\
\hline $\begin{array}{l}\text { Loja de } \\
\text { conveniência }\end{array}$ & $50-250$ & 1.000 & $1-2$ & $\begin{array}{l}\text { Mercearia, frios e } \\
\text { laticínios, bazar, } \\
\text { snacks }\end{array}$ \\
\hline $\begin{array}{l}\text { Loja de } \\
\text { sortimento } \\
\text { limitado }\end{array}$ & $200-400$ & 700 & $2-4$ & $\begin{array}{l}\text { Mercearia, frios e } \\
\text { laticínios, hortifruti, } \\
\text { bazar }\end{array}$ \\
\hline $\begin{array}{l}\text { Supermercado } \\
\text { compacto }\end{array}$ & $300-700$ & $4.000-7.000$ & $2-6$ & $\begin{array}{l}\text { Mercearia, frios e } \\
\text { laticinios, hortifruti, } \\
\text { carnes e aves, bazar }\end{array}$ \\
\hline $\begin{array}{l}\text { Supermercado } \\
\text { convencional }\end{array}$ & $700-2500$ & $9.000-12.000$ & $7-20$ & $\begin{array}{l}\text { Mercearia, frios e } \\
\text { laticínios, hortifruti, } \\
\text { carnes e aves, } \\
\text { padaria, bazar }\end{array}$ \\
\hline $\begin{array}{l}\text { Superloja } \\
\text { atacadista }\end{array}$ & $3000-5000$ & $14.000-20.000$ & $25-36$ & $\begin{array}{l}\text { Mercearia, frios e } \\
\text { laticínios, hortifruti, } \\
\text { carnes e aves, } \\
\text { peixaria, padaria, } \\
\text { bazar, têxtil e } \\
\text { eletroeletrônico }\end{array}$ \\
\hline depósito & $4.000-7000$ & 7.000 & $30-50$ & $\begin{array}{l}\text { Mercearia, frios e } \\
\text { laticínios, hortifruti, } \\
\text { carnes e aves, } \\
\text { peixaria, padaria, } \\
\text { bazar, têxtil e } \\
\text { eletroeletrônico }\end{array}$ \\
\hline Clube & $5.000-12.000$ & 5.000 & $\begin{array}{l}\text { Mercearia, frios e } \\
\text { laticinios, hortifruti, } \\
\text { carnes e aves, bazar }\end{array}$ \\
\hline
\end{tabular}

Fonte: Adaptado de ABRAS (2004) 
Ao se estudar a evolução dos supermercados, verifica-se que o layout das lojas mudou, parte em função da mudança dos hábitos de compra do consumidor, mas tarmbém por questões logísticas. Na década de 60, o destaque dos supermercados era o setor de mercearia, onde os principais itens eram os cereais e os enlatados. Após este período, a busca por alimentos pereciveis cresceu, passando este setor a ocupar $35 \%$ da área de vendas. Para os especialistas de economia, o setor de pereciveis deve crescer muito nos próximos anos. As seções de FLV (frutas, legumes e verduras), peixaria e alimentos prontos (Rotisserias) devem ser os que ganharão mais espaço dentro das lojas (ASCAR,1999 apud PARENTE, 2000).

O layout das lojas de supermercados ou hipermercados não é defirido por uma norma, mas é uma convenção adotada pela maioria das empresas. Por questões operacionais e de equipamentos, o recebimento de produtos (mercearia seca, perecíveis, higiene e limpeza) e depósitos (incluindo câmaras frigoríficas), ficam no fundo do estabelecimento. O setor de pereciveis geralmente também fica fundo da loja para facilitar a logística, ou seja, o abastecimento de balcões e ilhas refrigeradas. A reposição de mercadorias na área de vendas deve ser realizada num curto espaço de tempo, garantindo assim a cadeia do frio necessária para a maioria dos produtos que compõe o mix deste setor. Embora esse sistema seja o mais comum no Brasil, também outros formatos são encontrados em nosso pais. A figura 4 mostra um exemplo de layout de um supermercado com destaque para o setor de perecíveis. 


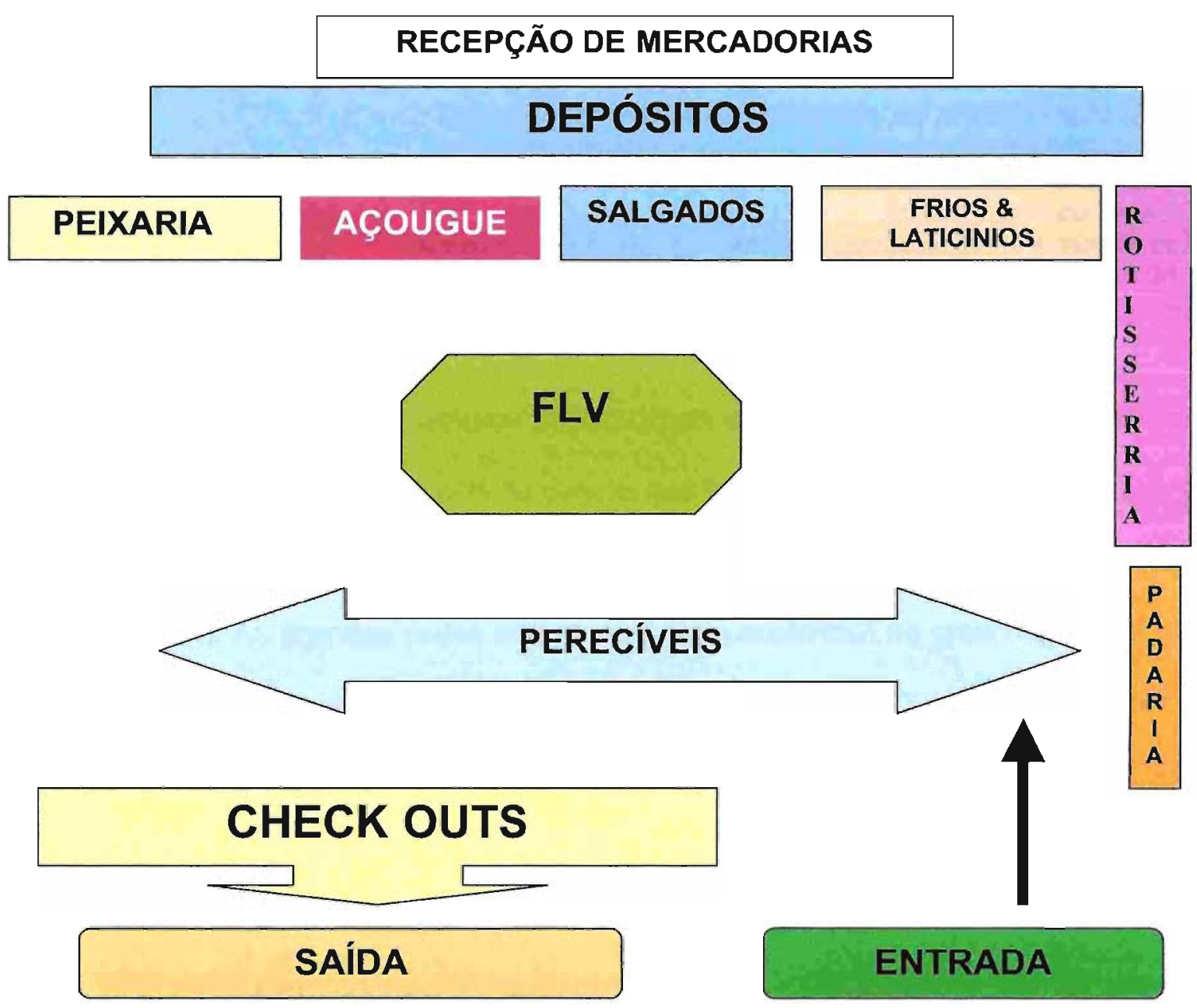

Figura 4: Layout do setor de pereciveis dentro de um supermercado Fonte: Adaptado de Parente (2000) 


\subsection{2 - SEÇÃO DE ROTISSERIA}

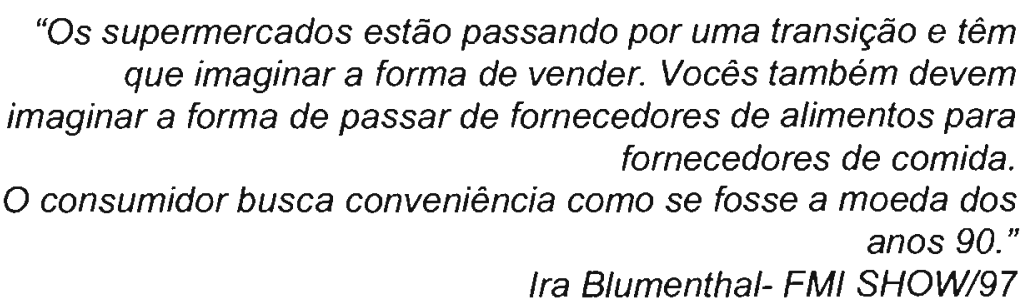

Visto como seção estratégica dentro do supermercado, a seção de rotisseria deve estar de acordo com o perfil do cliente que freqüenta o estabelecimento. Deve oferecer bons produtos, preços e serviços que diferenciem a loja da concorrência (BRITO, 2004). As grandes redes são as que mais acreditam no crescimento dessa seção. Uma das maiores empresas do setor, que possui 123 lojas operando no Estado de São Paulo, implantou rotisserias em 101 lojas. Destas, 71 têm áreas para o cliente consumir a refeição na própria loja, incluindo áreas para café (CARVALHO, 2005).

Segundo Beth Furtado, diretora de planejamento da Agência Talent (CARVALHO, 2005)

\footnotetext{
"A oferta de refeições e pratos prontos é também uma forma de atrair e fidelizar mais clientes, tornando o dia-a-dia deles mais cômodo e prático. Outra vantagem dos supermercados é a segurança e conforto nos estabelecimentos. Muitas lojas possuem estacionamento e aceitam pagamentos em cartão de crédito"
}

Para sua implantação, o empresário deve avaliar alguns aspectos que são imprescindíveis nessa seção: definir o seu conceito e objetivo e como poderá alcançá-lo. Definido qual o conceito a ser adotado, algumas redes de supermercados seguem o mesmo para todas as lojas. Uma rede de supermercados em São Paulo definiu como estratégia ser "supermercados de conveniência" que seguissem o mesmo padrão que a matriz na Europa, que vende pratos prontos 
resfriados. A empresa iniciou este tipo de atividade em 3 das trinta lojas implantando cozinhas industriais completas para o preparo das refeições. Os alimentos são expostos nos balcões refrigerados e o cliente escolhe qual e quanto deseja de cada preparação.

Porém, ter o mesmo serviço em todas as lojas pode não ser uma boa opção, conforme observado por Brito (2004):

\footnotetext{
"A implantação do setor e seu potencial de resultados depende de fatores que se alteram de loja para loja, como o perfil de sua clientela e a concorrência local, que não é só supermercados. O empresário deve saber e conhecer a concorrência local como as rotisserias, lanchonetes, padarias"
}

Neste tipo de serviço foram identificadas diferentes formas na montagem da seção onde há preparo e oferta de alimentos prontos:

1. Lojas que preparam os pratos no próprio estabelecimento e que dispõem de uma cozinha industrial com instalações e equipamentos próprios. A definição do cardápio é do supermercado, de acordo com o perfil da clientela ou por sugestão de clientes;

2. Lojas que comercializam alimentos prontos em balcões próprios mas os alimentos são preparados por fornecedores (cozinha industrial ou restaurante da vizinhança). A definição do cardápio é feita em parceria pelos responsáveis do supermercado, que conhecem o perfil dos clientes, e pela empresa fornecedora. A exposição à venda pode ser de duas formas: as lojas expõem as preparações em balcão refrigerado e atendem o consumidor conforme sua solicitação e lojas que recebem os alimentos já porcionados e embalados pelo fornecedor. 
3. Lojas de "Terceira Geração", que constituem um novo conceito para o serviço de refeições elaboradas em supermercados. Essas lojas fazem parcerias com empresas renomadas do setor de refeições (restaurantes e fast-food), tais como fábricas de massas frescas, com assinatura de chefs renomados, balcão de comida japonesa, carnes nobres e grelhados, além de sanduíches especiais. Este tipo de serviço é bastante recente e traz como inovação o conceito de "loja dentro de loja", no qual o parceiro é responsável pelos equipamentos e pela mão-de-obra.

O conceito de "loja de terceira geração" é recente e reflete uma tendência do varejo de se aproximar do consumidor, atendo seu desejo de poder adquirir refeições prontas, bem elaboradas e com preços competitivos, sem ter que ir a restaurantes.

De acordo com Brito (2004), se bem trabalhada, a seção pode agregar valor, aumentar o giro de produtos e elevar a margem de contribuição aos lucros totais da loja. Para Lukianocenko (2005), a rotisseria é hoje uma seção atraente e com muitas possibilidades. Novos equipamentos, como fornos para assar frango e equipamentos para exposição, devem ser planejados para a seção.

A ampliação das rotisserias em supermercados também está acontecendo em outras cidades brasileiras, conforme a matéria publicada pela ABRAS "Qualidade e muita variedade". Em uma rede de supermercado do Mato Grosso, que tem 12 lojas localizadas em Cuiabá e no interior do Estado, a seção de rotisseria conta com mais de 60 tipos de pratos típicos da região e outras consagradas comidas típicas brasileiras. Em uma das lojas, que funciona 24 horas, é possivel o cliente encontrar a qualquer hora preparações como feijoada, carne assada, arroz de carreteiro, farofa e lasanha. 
Para ter uma seção de rotisseria como esta, é necessário ter a clareza de que se trata de um local de preparo de alimentos, devendo ter estrutura e pessoal capacitado. Segundo Brito (2005), o empresário deve providenciar uma área adequada, além de observar questões legais e técnicas para segurança dos alimentos, ou seja, implantar as Boas Práticas. A padronização das receitas e um cardápio variado também são importantes para o sucesso do empreendimento.

Conforme o PAS (Programa Alimento Seguro), para a existência de um ponto de venda de rotisseria, faz-se necessária uma cozinha de apoio, que deve ser planejada para atender exigências legais e demanda do serviço (SENAI/SENAC/SESI/SEBRAE/AINVISA, 2005).

Para a implantação e funcionamento da seção de rotisseria em supermercados no Município de São Paulo, deve-se observar a legislação em vigor, a Portaria Municipal de São Paulo 2.535/03-SMS.G. Porém, existem ainda as recomendações das Portarias - Estadual de São Paulo CVS n6/99 (Regulamento Técnico sobre os Parâmetros e Critérios para o Controle Higiênico-Sanitário em Estabelecimentos de Alimentos) e a recente Resolução da ANVISA RDC 216 Regulamento Técnico de Boas Práticas para Serviços de Alimentação (ANVISA, 2004). Existem algumas diferenças entre essas normas, mas em todas estas há regras quanto a edificações e instalações, com distinção das seguintes áreas:

\footnotetext{
- Área de recebimento;

- Área de armazenamento;

_ Área de pré-preparo;

- Área de preparo/cocção;

_ Área de lavagem.
} 
Nas normas, há referências para os equipamentos, móveis e utensilios que devem ser de material sanitário e resistentes às operações de higienização, devendo ser mantidos em bom estado de conservação. Devem ser dimensionados ao tipo de cardápio e a quantidade de alimentos que serão preparados. O local para implantação desta seção deve ter um fluxo contínuo, sem cruzamentos de áreas sujas com limpas. Esta recomendação é importante para que não ocorra a contaminação cruzada por microrganismos deteriorantes ou patogênicos. Na seção de rotisseria, os alimentos podem ser comercializados de diferentes formas, portanto os equipamentos devem ser próprios para expor alimentos de maneira a garantir a segurança do alimento e suas caracteristicas sensoriais.

Outros cuidados estabelecidos na Portaria 2.535 do Município de São Paulo são:

A higienização das instalações, equipamentos, móveis e utensílios deve atender a um programa pré-estabelecido e ser executado por profissionais treinados; os produtos de higiene devem ser próprios para esta finalidade e ter registro no Ministério da Saúde.

Deve haver um controle de pragas, a ser realizado por empresas especializadas e devidamente licenciadas no órgão regulador.

Em locais onde há preparo de refeições, deve haver a guarda de amostras dos alimentos preparados, com o objetivo de esclarecimento de ocorrência de falhas de qualidade ou risco à saúde do consumidor. No caso de pratos prontos para o consumo, as amostras devem ser guardadas por 72 horas.

> Todos os profissionais de estabelecimentos de alimentos que trabalham na produção, desde o recebimento da matéria prima até o 
produto final e sua distribuição, devem ser continuamente treinados em boas práticas de fabricação/manipulação, além de terem exames de saúde de acordo com a recomendação da legislação vigente. Estas recomendações incluem proprietários, gerentes e supervisores.

Os alimentos prontos expostos para o consumo devem permanecer protegidos de contaminações e sob controle de tempo e temperatura, segundo os seguintes critérios:

a. Alimentos quentes devem ser mantidos a $65^{\circ} \mathrm{C}$ por até 12 horas, a $60^{\circ} \mathrm{C}$ por até no máximo por 6 horas e abaixo de $60^{\circ} \mathrm{C}$, no máximo por 1 hora

b. alimentos frios, como sobremesas, frios e laticínios manipulados devem ser mantidos a $8^{\circ} \mathrm{C}$ por até 24 horas, a $6^{\circ} \mathrm{C}$ por até 48 horas e a $4^{\circ} \mathrm{C}$ por até 72 horas

A documentação e os registros de oprações devem ser realizados, arquivados e apresentados à autoridade sanitária quando solicitados. 


\subsection{3 - DADOS ATUAIS DO SETOR SUPERMERCADISTA}

Os principais resultados do ano de 2.004 para o auto-serviço alimentar brasileiro, segundo a ABRAS, foram:

_ faturou $\mathrm{R} \$ 87,2$ bilhões em 2003

_ o número de empregos diretos gerados pelo setor cresceu 2,9\% em relação ao ano anterior

_ o número de lojas foi $3,6 \%$ a superior ao do no ano anterior

_ expandiu a área de vendas $11,9 \%$ em relação ao ano anterior

_ $\quad$ mais de $90 \%$ das lojas no país estão automatizadas

- a região sudeste responde por $58 \%$ do total das vendas, ou seja do faturamento do setor

_ O Estado de São Paulo responde por 39\% do faturamento total do setor, Rio de Janeiro $10,77 \%$ e Rio Grande do Sul $9,54 \%$

_ Na participação das seções em importância de vendas, os perecíveis ficam com 34,8\%. Essa participação aumentou em relação ao ano anterior, enquanto que a de mercearia diminuiu

_ Na seção de pereciveis a participação foi: frios e laticinios 12,9\%, açougue representa $7,9 \%$, FLV $6,3 \%$, padaria e confeitaria $3,2 \%$, congelados $3 \%$, a peixaria $1,1 \%$ refeições prontas (rotisseria) $0,5 \%$. 


\section{3- OBJETIVOS}

Esse trabalho objetivou fazer um estudo crítico da situação de supermercados que, além de comercializarem produtos industrializados (alimentos e não alimentos), iniciaram a produção e comercialização de refeições prontas para o consumo. Avaliou-se as implicações dessa atividade em relação à qualidade e segurança dos alimentos produzidos e comercializados e as conseqüências para a saúde do consumidor. Para ilustrar o estudo, selecionou-se um supermercado que adaptou um local para produção e comercialização de refeições prontas, avaliando-se as condições higiênicas gerais de acordo com a Lista de Verificação de Boas Práticas de Manipulação em Estabelecimentos de Alimentos, estabelecida pela PMSP/SEMAB/DIMA, 2002, como também o atendimento da Resolução RDC №12 da ANVISA, 2001, referente ao item 22 (Pratos prontos para o consumo: alimentos prontos de cozinhas, restaurantes e similares) de alguns pratos prontos para o consumo produzidos nesse estabelecimento. 


\section{4 - MATERIAIS E MÉTODOS}

\section{1 - MATERIAIS}

O histórico do setor supermercadista e seu envolvimento no comércio de alimentos preparados prontos para consumo foram estudados à luz de informações obtidas principalmente no Instituto Histórico da Associação Brasileira de Supermercados.

Para ilustrar este trabalho foi selecionado um supermercado que contava com uma seção de rotisseria, provido de uma cozinha onde se preparavam alimentos comercializados no próprio supermercado. Tanto a área de preparo quanto a de comercialização foram adaptadas ao layout da loja.

O estabelecimento estudado é uma loja de vizinhança, isto é, localiza-se em uma zona residencial e atende principalmente a comunidade local. Conforme a Tabela de Classificação da ABRAS, trata-se de um supermercado pertencente à categoria "compacto". Possui área de vendas de 600 metros, tem 4 checkouts e 49 funcionários. O supermercado possui as seguintes seções:

1- Padaria e confeitaria

2- Açougue

3- Frios e laticinios Setor de Pereciveis

4- Setor de Pratos Prontos/Rotisserie

5- FLV

6- Mercearia

7- Higiene e limpeza

8- Bazar

Este estabelecimento funciona de segunda à sábado no horário de 8:00 horas às 20:00 horas e aos domingos de 8:00 horas às 13:00 horas. O horário de 
exposição dos alimentos prontos da rotisseria inicia-se às 10:30 horas e encerra-se às 19:30 horas.

O local de preparo dos alimentos (cozinha) ocupa uma área adaptada num mezanino. O espaço é dividido entre duas seções: de um lado fica a cozinha industrial, de outro fica a panificação. A cozinha possui um fogão industrial de seis bocas, mesas de apoio, geladeira, freezer, prateleiras e utensilios diversos (panelas, garfos, facas, travessas, recipientes plásticos).

A área para exposição à venda também é adaptada à loja, anexa à seção de Frios e Laticínios. O local possui mesas que unidas entre si formam um balcão onde são expostas as preparações para venda ao consumidor. Os alimentos prontos são expostos à venda em travessas de louça. O consumidor escolhe os produtos, que são colocados em embalagens descartáveis (alumínio ou plástico) e posteriormente pesados em balança local.

O estabelecimento de estudo possui mais de cem preparações diferentes cadastradas. O cardápio diário é determinado pela responsável da seção (encarregada) e também por sugestões de clientes e proprietários. Algumas preparações tem grande demanda e são expostas à venda todos os dias, enquanto outras seguem um rodizio.

\subsection{1 - DESCRIÇÃO DAS PREPARAÇÕES}

\section{Lagarto a Escabeche e Lagarto com Aliche:}

Pela semelhança, as preparações serão descritas juntas. A carne é proveniente do açougue do próprio estabelecimento, é recebida com osso e em seguida desossada e separada em cortes. O corte utilizado é o lagarto. A carne é cozida por funcionários do período noturno em fogo brando durante 3 horas. 0 produto atinge a temperatura de $74^{\circ} \mathrm{C}$ no centro geométrico das peças, conforme 
recomendação da legislação em vigor (PORTARIA SMS 2535/04). Após a cocção, o produto é mantido em temperatura ambiente até o dia seguinte, permanecendo nesta condição por pelo menos 7 horas. A carne cozida é fatiada em fatias bem finas, empregando-se a máquina de fatiar do setor de frios e laticínios, e acondicionada em vasilhas plásticas. As peças de carne cozida não fatiadas são embaladas separadamente em filme PVC e armazenadas na única câmara frigorífica do supermercado, localizada entre o açougue e a seção de frios e laticínios. Estas peças de carne permanecem armazenadas em refrigeração até sua utilização. $A$ temperatura da câmara frigorifica em algumas ocasiōes, chegou a $11,3^{\circ} \mathrm{C}$.

A figura 5 mostra as preparações e a figura 6, o fluxograma do preparo do lagarto a escabeche e do lagarto com aliche.

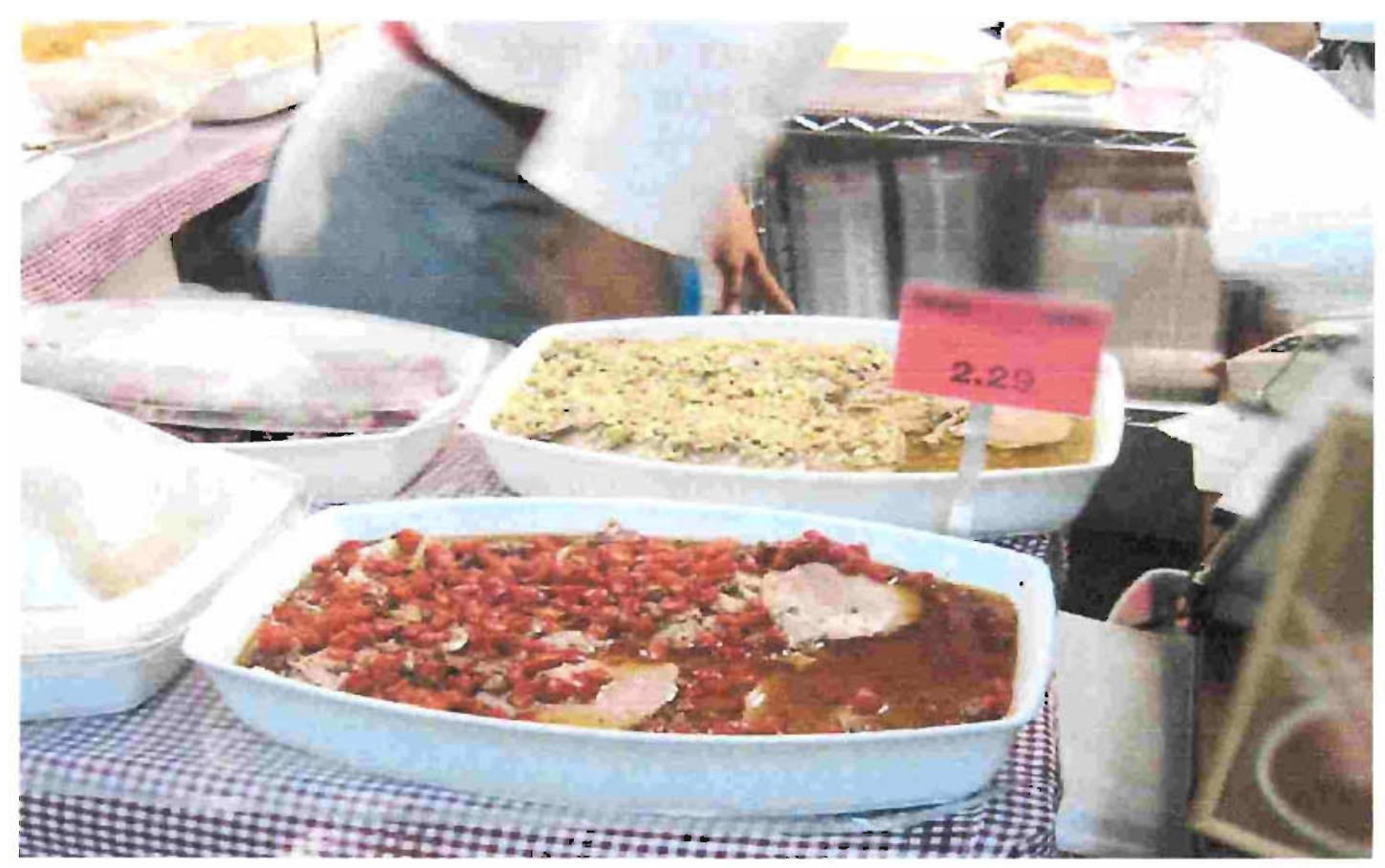

Figura 5: Foto das preparações lagarto a escabeche e lagarto com aliche 


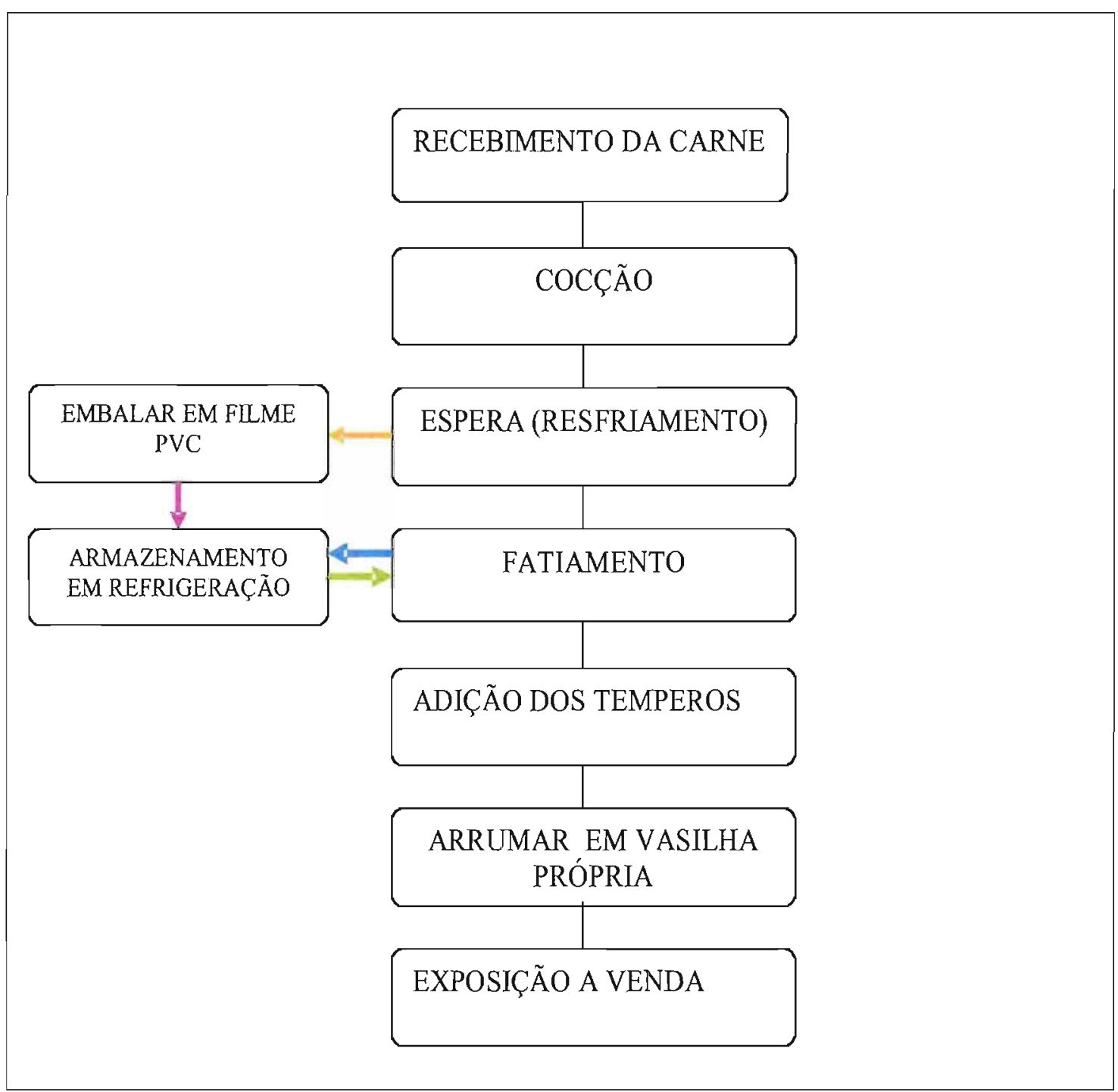

Figura 6: Fluxograma de preparo do lagarto a escabeche e lagarto com aliche 


\section{Carne Assada com Molho Ferrugem (figura 7):}

O processo de preparo é semelhante ao descrito para o lagarto, isto é, cocção durante 4 horas realizado pelos funcionários do período noturno. A carne cozida é mantida em temperatura ambiente. Ao molho da carne cozida são adicionados temperos e farinha de trigo para melhorar o sabor e consistência. No período da manhã, a carne cozida e mantida em temperatura ambiente é fatiada, arrumada em vasilha de louça idêntica a do lagarto. No momento de ser colocada em exposição à venda, o molho quente é acrescentado sobre as fatias. Também este produto é fatiado apenas quando necessário. As peças de carne não fatiadas são embaladas em filme PVC, etiquetadas com datas de validade e armazenadas na câmara frigorífica da seção de frios e laticínios. A figura 8 apresenta o fluxograma de preparo da carne assada ao molho ferrugem.

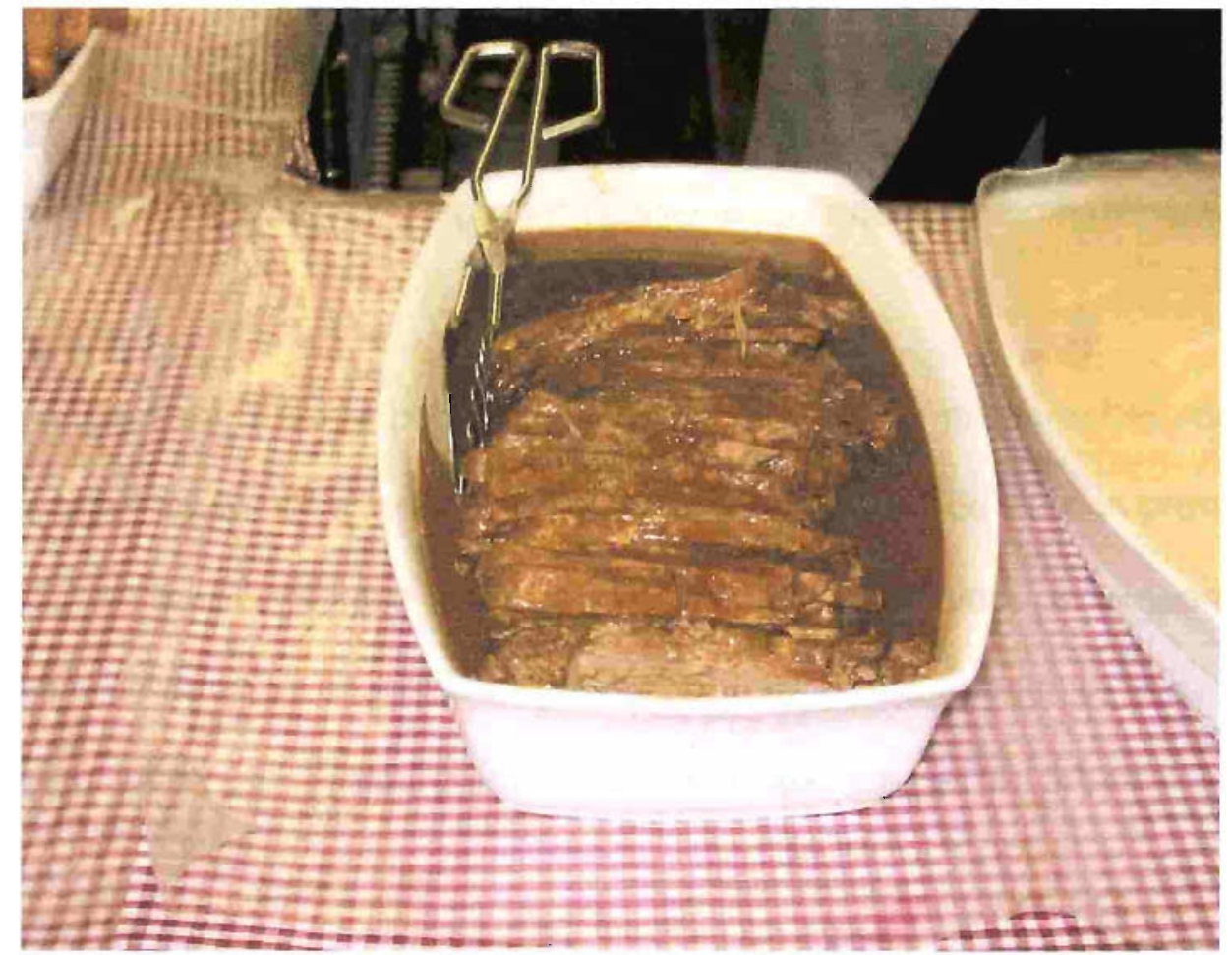

Figura 7: Foto da carne assada na área de vendas da rotisseria 


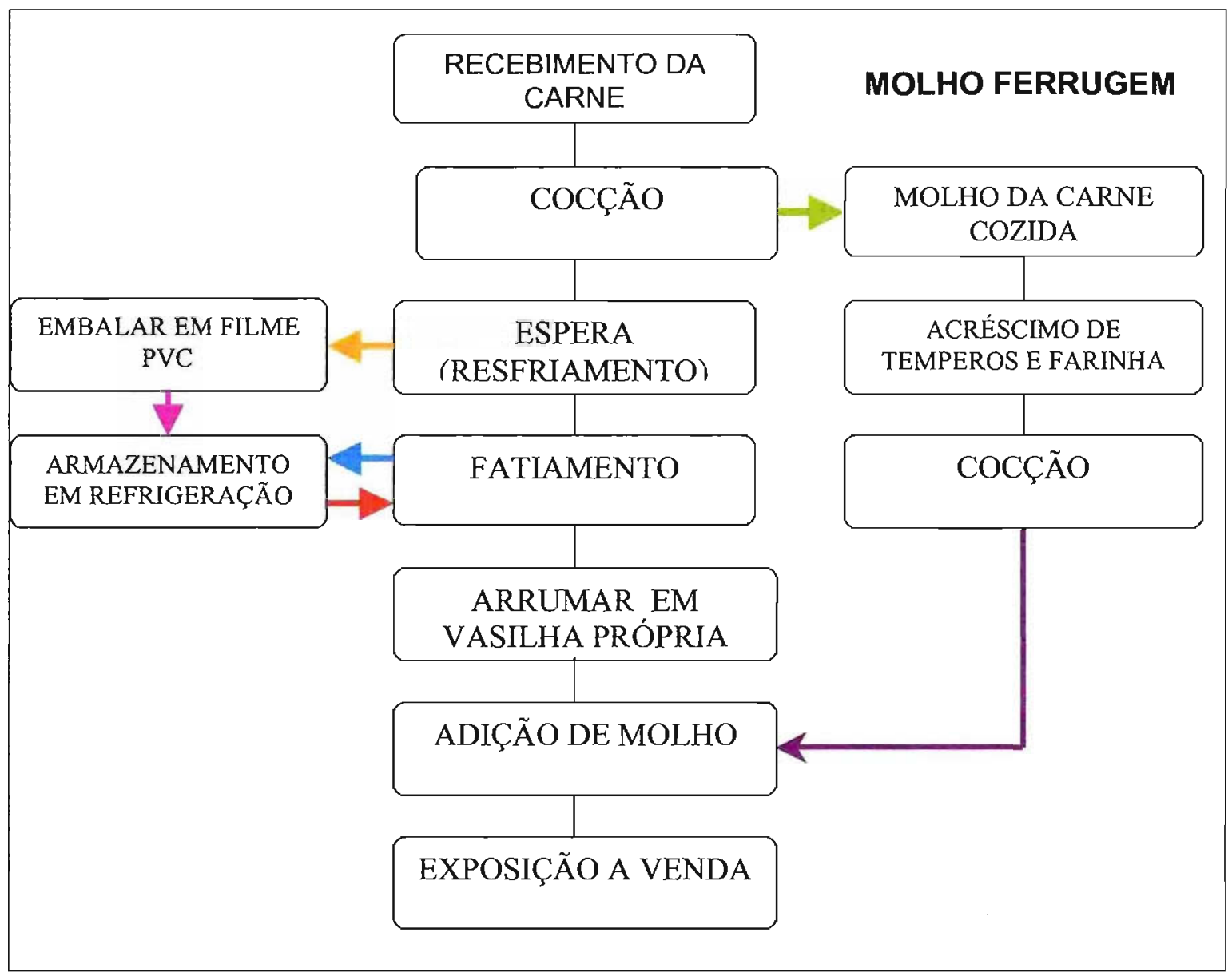

Figura 8: Fluxograma do preparo da carne assada com molho ferrugem

\section{Batata Aperitivo:}

A origem da matéria prima é a mesma das outras preparações, ou seja, o próprio estabelecimento, sendo que neste caso foi a seção de FLV. A preparação é constituida de batata inglesa (tipo bolinha) cozida com casca e temperada com azeite, sal e orégano. A exposição à venda também é em travessas de louça e em temperatura ambiente. A figura 9 apresenta o fluxograma de preparo da batata aperitivo. 


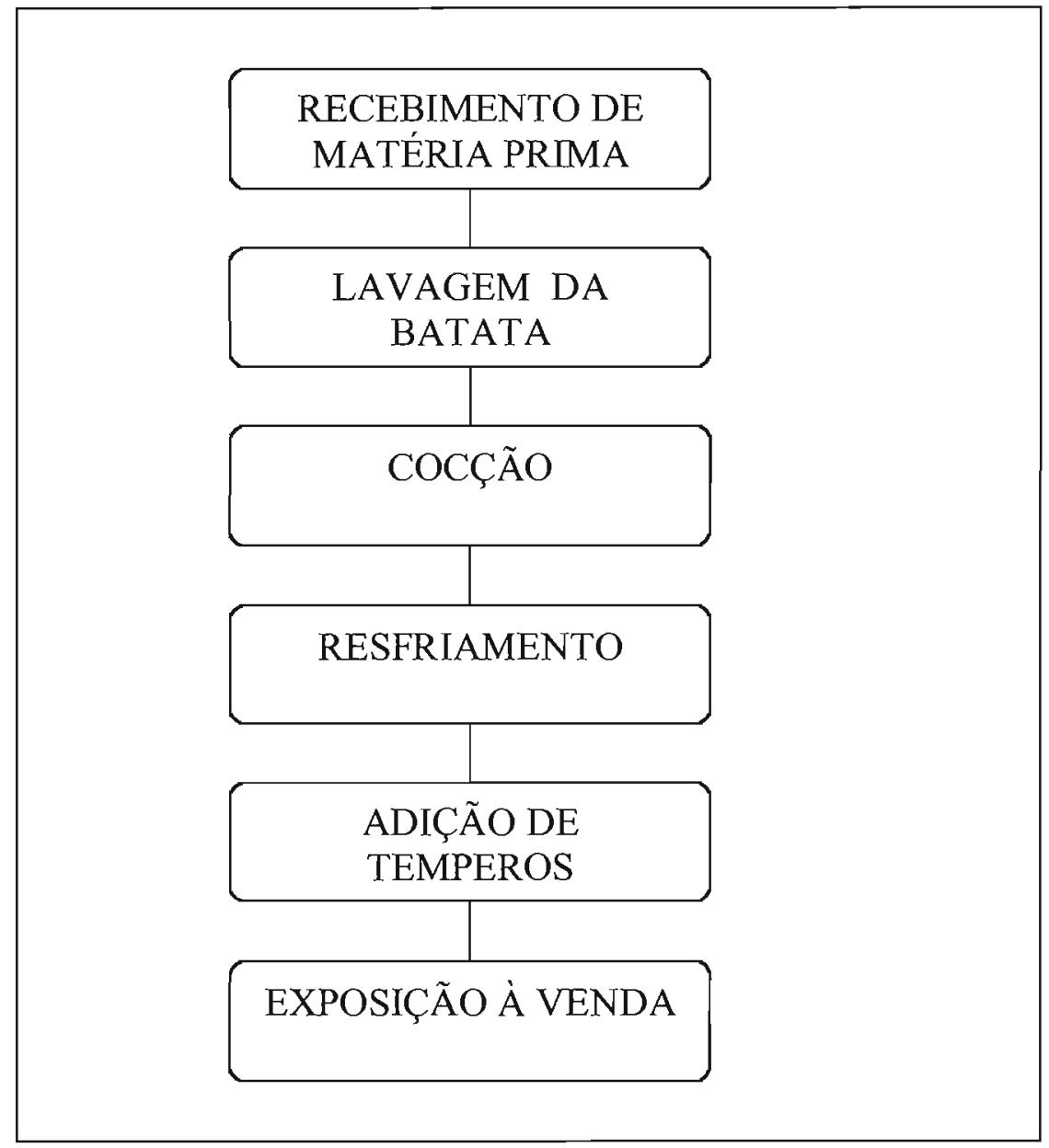

Figura 9: Fluxograma de preparo da batata aperitivo

\section{Maionese de Legumes:}

Origem dos legumes é a seção de FLV. Os legumes utilizados são batata inglesa, cenoura e vagem. Os legumes são descascados, picados em máquina própria e depois cozidos. Após a cocção, são escorridos e permanecem em temperatura ambiente. É adicionado molho de maionese industrializado. O produto é colocado em vasilha de louça e exposto ao consumidor. A figura 10 apresenta o fluxograma do preparo da maionese de legumes. 


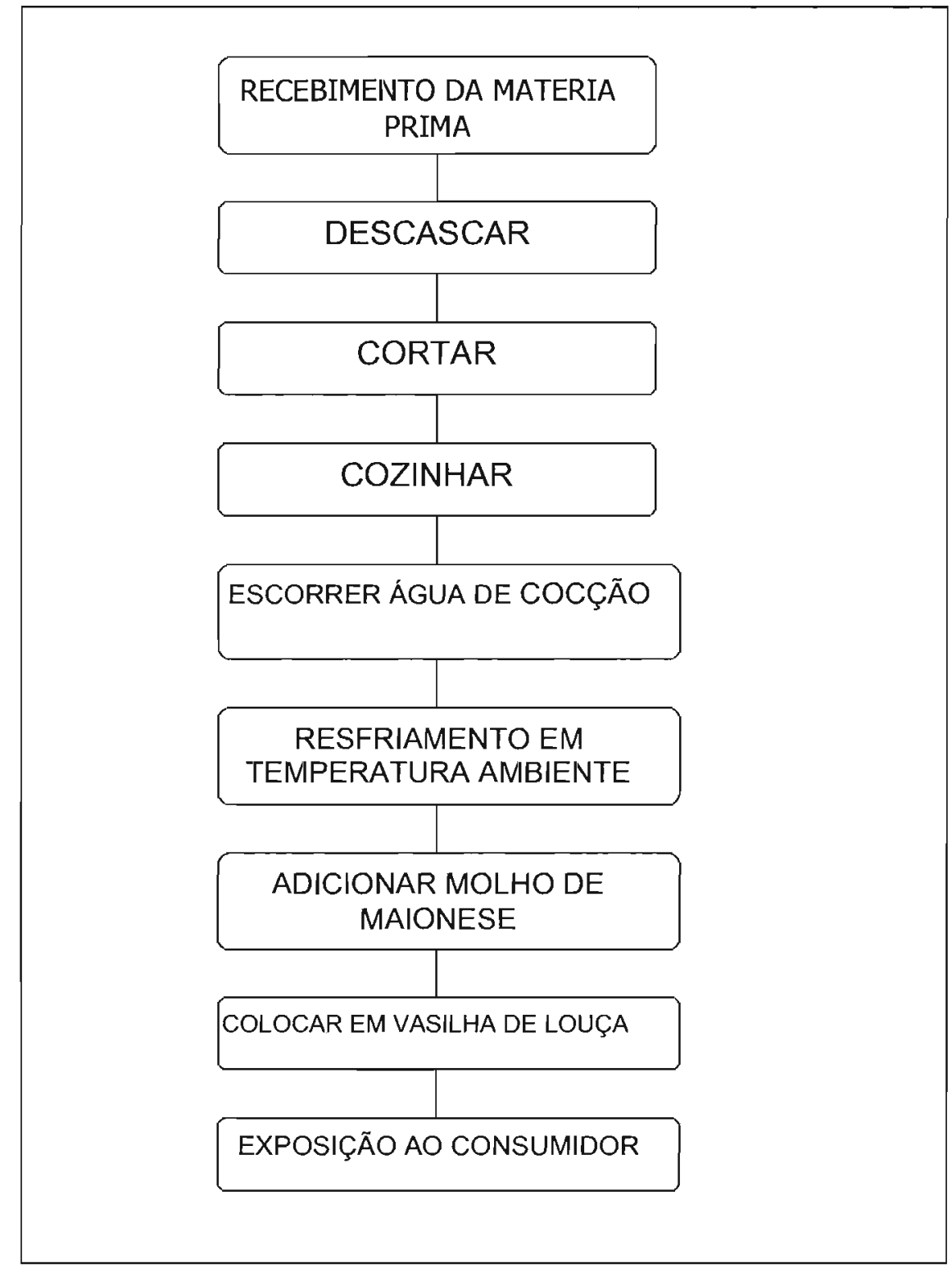

Figura 10: Fluxograma de preparo da maionese de legumes

\section{Farofa de Carne:}

Todos os ingredientes são provenientes das seções do supermercado. Os ingredientes desta preparação são a farinha de mandioca, margarina, ovos, cebola, carne cozida e desfiada. A figura 11 apresenta o fluxograma de preparo da farofa. 


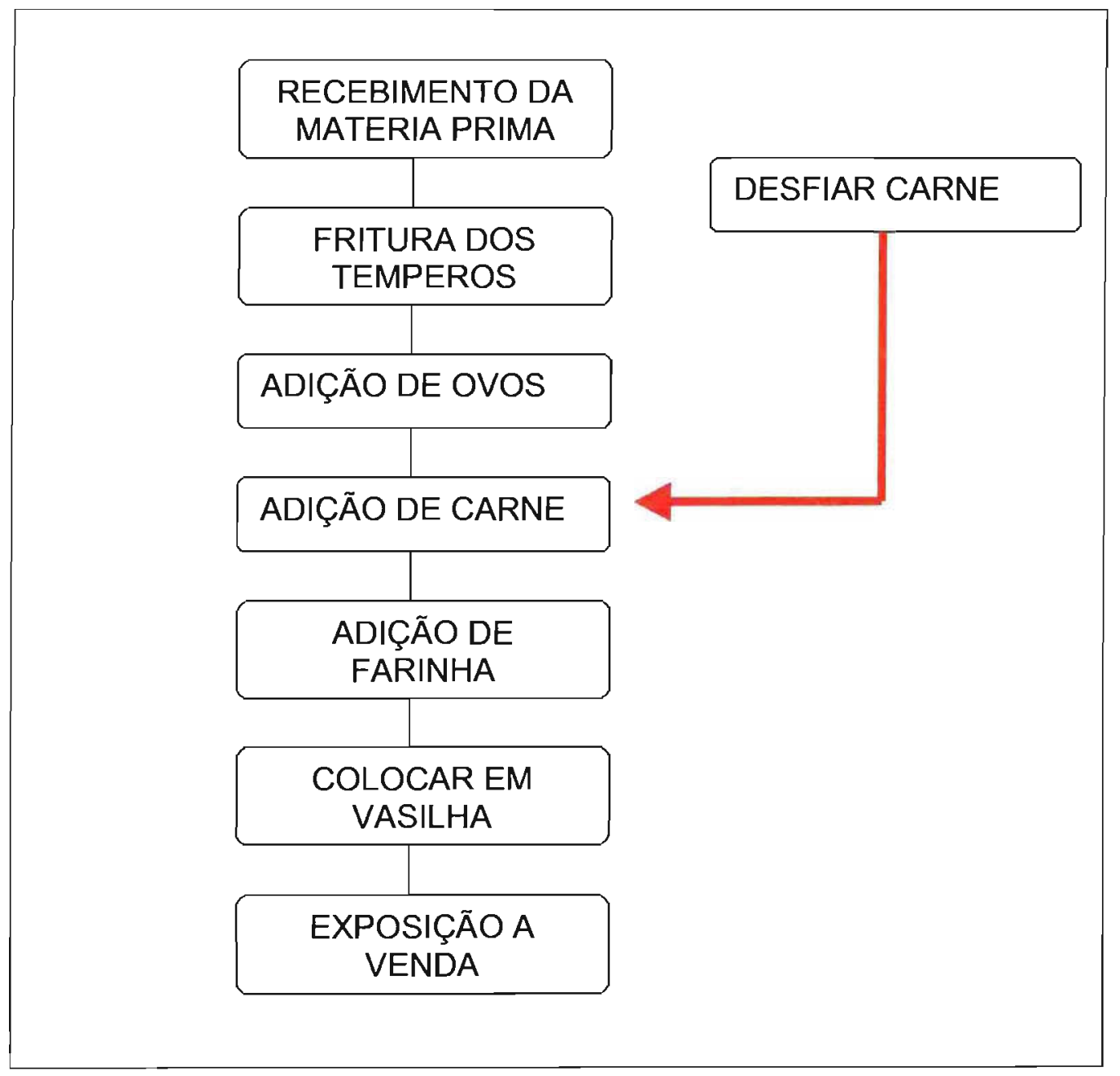

Figura 11: Fluxograma de preparo da farofa de carne 


\section{2 - MÉTODOS}

\subsection{1 - VERIFICAÇÃO DO USO DAS BPM}

Durante o período de estudo, foram realizadas visitas aleatórias ao supermercado selecionado. Nessas visitas, feitas sem aviso prévio, fez-se um diagnóstico da seção de rotisseria através da aplicação da Lista de Verificação das Boas Práticas de Manipulação em Estabelecimentos da Área de Alimento da Prefeitura do Município de São Paulo (SÃO PAULO, 2002) utilizada pelo Grupo Técnico Fiscalizador por ocasião das inspeções Sanitárias nos Estabelecimentos Comerciais. Este instrumento de diagnóstico apresenta "pesos" para cada um dos blocos de requisitos avaliados. Cada bloco possui itens classificados como "imprescindiveis", correspondentes a aqueles que influem em grau crítico na qualidade ou segurança do produto ou processo, "necessários", correspondentes a aqueles que influem em grau menos crítico na qualidade ou segurança do produto ou processo, e "recomendáveis", correspondes a aqueles que influem em grau não crítico na qualidade ou segurança do produto ou processo.

Os blocos avaliados são:

\section{A- Edificação e Instalações:}

- área externa

o acesso

$\circ$ piso

o tetos

- paredes e divisórias

○ portas e janelas

- iluminação

- ventilação 
○ instalações sanitárias para manipuladores

○ vestiários

○ instalações sanitárias para o público

- abastecimento de água potável

- destino de resíduos

Neste bloco de requisitos, cinco são classificados como "imprescindível", 44 como "necessário" e um como "recomendável" .

\section{B- Equipamentos, móveis e utensílios}

- equipamentos e maquinários

o móveis

- limpeza e desinfecção dos equipamentos e utensílios

Neste bloco de requisitos, dois são classificados como "imprescindível", sete como "necessário" e nenhum como "recomendável".

\section{C- Manipuladores}

○ vestuário

○ asseio pessoal

○ hábitos higiênicos

- estado de saúde

Neste bloco de requisitos, dois são classificados como "imprescindivel", quatro como "necessário" e nenhum como "recomendável".

\section{D- Fluxo de Produção}

- matéria-prima/insumos

○ fluxo de produção/manipulação/expedição/venda

○ proteção contra a contaminação

- manipulação dos alimentos 
○ embalagem/rotulagem

o armazenamento e acondicionamento de produtos

Neste bloco de requisitos, oito são classificados como "imprescindivel", 30 como "necessário" e nenhum como "recomendável".

\section{E- Programa de Controle de Qualidade - Boas Práticas de Fabricação}

- manual de boas práticas

- programa de controle de pragas

- programa de treinamento de pessoal e supervisão

- programa de controle de saúde

o programa de recolhimento

Neste bloco de requisitos, nenhum é classificado como "como "imprescindível", quatro como "necessário" e nenhum como "recomendável".

Após a verificação, o estabelecimento recebe uma classificação dividida da seguinte forma:

- Baixo risco: Atende a todos os itens imprescindiveis

- Médio risco: Atende parcialmente aos itens imprescindiveis, porém não compromete a segurança do alimento

- Alto risco: Não atende aos itens imprescindiveis e compromete a segurança do alimento.

A seguir está o modelo da Lista de Verificação das Boas Práticas de Manipulação em Estabelecimentos da área de Alimentos que foi utilizada como roteiro neste estudo. 
PREFEITURA DO MUNICÍPIO DE SÃO PAULO

SECRETARIA MUNICIPAL DE ABASTECIMENTO

DEPARTAMENTO DE INSPECC̃OO MUNICIPAL DE ALIMENTOS - DIMA

AV. GUILHERME, 82 - VL. GUILHERME

\section{LISTA DE VERIFICAÇÃO DAS BOAS PRÁTICAS DE MANIPULAÇÃO EM ESTABELECIMENTOS DA ÁREA DE ALIMENTOS}

\begin{tabular}{|c|c|c|c|}
\hline A- AVALIAÇÃO & SIM & NÃO & Observação \\
\hline \multicolumn{4}{|l|}{ 1. Edificação e Instalações } \\
\hline $\begin{array}{l}\text { 1.1. Área externa: Área livre de focos de } \\
\text { insalubridade, de objetos em desuso, } \\
\text { de animais (inclusive insetos e } \\
\text { roedores) e de água estagnada e } \\
\text { outros focos de contaminação dos } \\
\text { alimentos. }\end{array}$ & & & $\mathbf{N}$ \\
\hline $\begin{array}{l}\text { 1.2. Acesso: Direto, não comum e } \\
\text { outros usos (habitação). }\end{array}$ & & & $\mathbf{N}$ \\
\hline $\begin{array}{l}\text { 1.3. } \\
\text { 1.3.1. } \\
\text { Material liso, resistente, } \\
\text { impermeável, de fácil limpeza. }\end{array}$ & & & $\mathbf{N}$ \\
\hline $\begin{array}{l}\text { 1.3.2. Em bom estado de conservação } \\
\text { (livre de defeitos, rachaduras, } \\
\text { buracos e outros). }\end{array}$ & & & $\mathbf{N}$ \\
\hline $\begin{array}{l}\text { 1.3.3. Declive, drenos, ralos sifonados e } \\
\text { grelhas fechadas. }\end{array}$ & & & $\mathbf{N}$ \\
\hline 1.3.4. Apresenta-se limpo. & & & $\mathbf{N}$ \\
\hline $\begin{array}{ll}\text { 1.4. } & \text { Tetos } \\
\text { 1.4.1. } & \text { Acabamento liso, impermeável, } \\
\text { lavável, em cor clara. }\end{array}$ & & & $\mathbf{N}$ \\
\hline $\begin{array}{l}\text { 1.4.2. Em bom estado de conservação } \\
\text { (livre de trincas, rachaduras, } \\
\text { umidade, bolor, descascamento). }\end{array}$ & & & $\mathbf{N}$ \\
\hline 1.4.3. Apresentam-se limpos. & & & $\mathbf{N}$ \\
\hline $\begin{array}{l}\text { 1.5. Paredes/divisórias } \\
\text { 1.5.1. Acabamento liso, impermeável, } \\
\text { lavável, em cor clara. }\end{array}$ & & & $\mathbf{N}$ \\
\hline $\begin{array}{l}\text { 1.5.2. Em bom estado de conservação } \\
\text { (livre de falhas, rachaduras, } \\
\text { umidade, bolor, descascamento). }\end{array}$ & & & $\mathbf{N}$ \\
\hline 1.5.3. Apresentam-se limpas. & & & $\mathbf{N}$ \\
\hline $\begin{array}{l}\text { 1.6. Portas e Janelas } \\
\text { 1.6.1. Com superfície lisa, de fácil } \\
\text { limpeza. }\end{array}$ & & & $\mathbf{N}$ \\
\hline 1.6.2. Em bom estado de conservação. & & & $\mathbf{N}$ \\
\hline 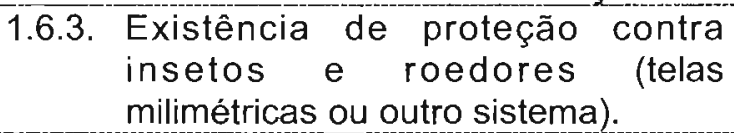 & & & $\mathbf{N}$ \\
\hline $\begin{array}{l}\text { 1.6.4. Portas externas ou de isolamento } \\
\text { com fechamento automático (mola). }\end{array}$ & & & $\mathbf{N}$ \\
\hline
\end{tabular}




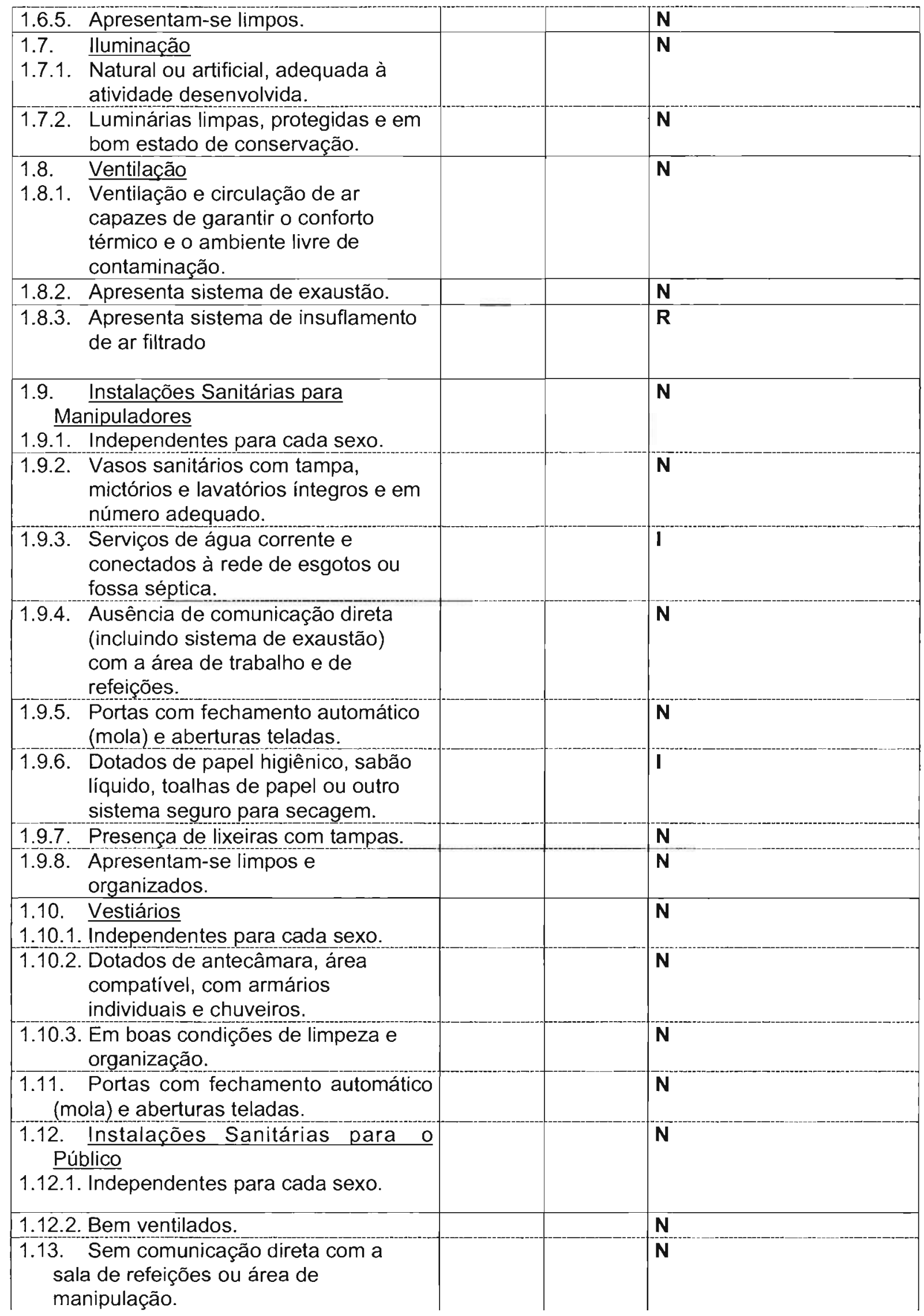




\begin{tabular}{|c|c|}
\hline $\begin{array}{l}\text { 1.13.1. Dotados de sabáo líquido, papel } \\
\text { higiênico, toalhas de papel. }\end{array}$ & $\mathbf{N}$ \\
\hline 1.13.2. Apresentam-se limpos. & $\mathbf{N}$ \\
\hline $\begin{array}{l}\text { 1.14. Abastecimento de Água Potável } \\
\text { 1.14.1. Abastecimento ligado à rede } \\
\text { pública e/ou existência de sistema } \\
\text { de captação próprio (poço) } \\
\text { protegido, revestido e localizado de } \\
\text { acordo com a legislação. }\end{array}$ & $\mathbf{N}$ \\
\hline $\begin{array}{l}\text { 1.14.2. Potabilidade atestada através de } \\
\text { laudos laboratoriais periódicos. }\end{array}$ & 1 \\
\hline 1.14.3. Caixas d'água dotadas de tampas. & $\mathbf{N}$ \\
\hline $\begin{array}{l}\text { 1.14.4. Execução de limpeza periódica da } \\
\text { caixa d'água. }\end{array}$ & $\mathbf{N}$ \\
\hline $\begin{array}{l}\text { 1.14.5. Gelo produzido a partir de água } \\
\text { potável. }\end{array}$ & I \\
\hline 1.15. Destino de Resíduos & \\
\hline $\begin{array}{l}\text { 1.15.1. Lixo no interior do estabelecimento } \\
\text { em recipientes tampados, para os } \\
\text { resíduos sólidos. }\end{array}$ & 1 \\
\hline 1.15.2. Recipientes limpos. & $\mathbf{N}$ \\
\hline 1.15.3. Uso de sacos de lixo apropriados. & $\mathbf{N}$ \\
\hline $\begin{array}{l}\text { 1.15.4. Depósito de lixo em local isolado, } \\
\text { protegido de sol, chuva, animais e } \\
\text { pessoas estranhas. }\end{array}$ & $\mathbf{N}$ \\
\hline $\begin{array}{l}\text { 1.15.5. Caixas de gordura fora da área de } \\
\text { manipulação. }\end{array}$ & $\mathbf{N}$ \\
\hline $\begin{array}{l}\text { 1.15.6. Caixas de gordura em bom estado } \\
\text { de conservação e funcionamento. }\end{array}$ & $\mathbf{N}$ \\
\hline \multicolumn{2}{|l|}{ 2. Equipamentos, móveis e utensillios } \\
\hline $\begin{array}{l}\text { 2.1. Equipamentos e Maquinários } \\
\text { 2.1. Equipamentos com modelos e } \\
\text { número adequado ao ramo, em } \\
\text { bom estado de conservação e } \\
\text { funcionamento. }\end{array}$ & $\mathbf{N}$ \\
\hline 2.1.2. Apresentam-se limpos. & I \\
\hline $\begin{array}{l}\text { 2.1.3. Câmaras frias de material } \\
\text { adequado, em bom estado de } \\
\text { conservação, ausência de ralo, } \\
\text { porta com dispositivo interno de } \\
\text { segurança, termômetro com } \\
\text { visualização externa. }\end{array}$ & $\mathbf{N}$ \\
\hline $\begin{array}{l}\text { 2.1.4. Câmaras frias em boas condições } \\
\text { de organização e limpeza. }\end{array}$ & $\mathbf{N}$ \\
\hline $\begin{array}{l}\text { 2.2. Móveis (mesas, bancadas, vitrines, } \\
\text { estantes) } \\
\text { 2.2.1. Em número suficiente, de material } \\
\text { apropriado, resistente, liso e } \\
\text { impermeável, com superficies } \\
\text { integras e em bom estado de } \\
\text { conservação. }\end{array}$ & $\mathbf{N}$ \\
\hline 2.2.2. Apresentam-se limpos. & $\mathbf{I}$ \\
\hline
\end{tabular}




\begin{tabular}{|c|c|}
\hline $\begin{array}{l}\text { 2.3. Limpeza e Desinfeç̧ão dos } \\
\text { Equipamentos e Utensílios } \\
\text { 2.3.1. Apresenta um local apropriado para } \\
\text { limpeza e desinfecção. }\end{array}$ & $\mathbf{N}$ \\
\hline $\begin{array}{l}\text { 2.3.2. Utiliza produtos de limpeza e } \\
\text { procedimentos corretos (frequêencia, } \\
\text { diluição, tempo, temperatura) }\end{array}$ & $\mathbf{N}$ \\
\hline 2.3.3. Existe registro dos procedimentos. & $\mathbf{N}$ \\
\hline
\end{tabular}

\section{Manipuladores}

3.1. Vestuário

3.1.1. Utilização de uniforme de trabalho adequado à atividade, de cor ou tonalidade clara.

3.1.2. Limpos e com bom estado de conservação.

3.2. Asseio Pessoal: Boa apresentação, asseio corporal, mãos limpas, unhas curtas, sem esmalte, sem adornos (anéis, pulseiras, brincos, etc.), manipuladores barbeados, com os cabelos e bigodes aparados e protegidos.

3.3. Hábitos Higiênicos

3.3.1. Lavagem cuidadosa das mãos antes da manipulação de alimentos.

3.3.2. Os manipuladores não fumam, não manipulam dinheiro e não praticam outros atos que possam contaminar o alimento.

3.4. Estado de Saúde

3.4.1. Ausência de afecções cutâneas, feridas e supurações, ausência de sintomas e infecções respiratórias, gastrointestinais e oculares.

\section{Fluxo de Produção}

4.1. Matéria-prima/insumos

4.1.1. Recepção: Área de recepção que garanta a sua qualidade, isolada da área de processamento.

4.1.2. As operações de carga e descarga são realizadas em local protegido das chuvas e sol, limpo e organizado.

4.1.3. Matérias-primas, ingredientes e materiais de embalagens inspecionados na recepção.

4.1.4. Procedência: matérias-primas e/ou insumos provenientes de fornecedores autorizados.

4.1.5. Embalagens e rótulos adequados à legislação vigente (prazos de validade, ingredientes, procedência)

\begin{tabular}{|l|l|l|}
\hline & & $\mathbf{N}$ \\
\hline & & $\mathbf{N}$ \\
\hline & & \\
\hline & & $\mathbf{N}$ \\
\hline & & $\mathbf{N}$ \\
\hline
\end{tabular}

\begin{tabular}{|l|l|l|}
\hline & & \\
\hline & & \\
\hline & & \\
\hline & & \\
\hline & & $\mathbf{N}$ \\
\hline & & \\
\hline
\end{tabular}




\begin{tabular}{|c|c|}
\hline $\begin{array}{l}\text { 4.1.6. As matérias-primas com prazo de } \\
\text { validade vencido, quando houver, } \\
\text { são identificadas e armazenadas } \\
\text { em local apropriado. }\end{array}$ & $\mathbf{N}$ \\
\hline $\begin{array}{l}\text { 4.1.7. Acondicionamento adequado das } \\
\text { matérias-primas }\end{array}$ & $\mathbf{N}$ \\
\hline $\begin{array}{l}\text { 4.1.8. Armazenamento em local ventilado, } \\
\text { sem presença de fungos; }\end{array}$ & $\mathbf{N}$ \\
\hline $\begin{array}{l}\text { 4.1.9. Armazenamento sobre estrados } \\
\text { distantes no mínimo de } 30 \mathrm{~cm} \text { do } \\
\text { piso ou sobre pallets, bem } \\
\text { conservados e limpos ou sobre } \\
\text { outro sistema aprovado, afastados } \\
\text { das paredes e do teto. }\end{array}$ & $\mathbf{N}$ \\
\hline $\begin{array}{l}\text { 4.1.10. Local de armazenamento em bom } \\
\text { estado de organização e limpeza. }\end{array}$ & $\mathbf{N}$ \\
\hline $\begin{array}{l}\text { 4.1.11. Rede de frio para conservação } \\
\text { adequada ao volume e aos } \\
\text { diferentes tipos de alimentos. }\end{array}$ & $\mathbf{I}$ \\
\hline $\begin{array}{l}\text { 4.2. } \frac{\text { Fluxo de }}{\text { Produção/Manipulação/Expedição }} \\
\frac{\text { Nenda }}{\text { 4.2.1. Ordenado, linear, sem cruzamento }} \\
\text { entre as linhas de produção. }\end{array}$ & $\mathbf{N}$ \\
\hline $\begin{array}{l}\text { 4.2.2. Locais para pré-preparo ("área } \\
\text { suja") isolados da área de preparo. }\end{array}$ & $\mathbf{N}$ \\
\hline $\begin{array}{ll}\text { 4.3. } & \text { Proteção Contra Contaminação } \\
\text { 4.3.1. } & \text { Alimentos protegidos. }\end{array}$ & $\mathbf{N}$ \\
\hline $\begin{array}{l}\text { 4.3.2. Substâncias perigosas como } \\
\text { inseticidas, detergentes e } \\
\text { desinfetantes identificados, } \\
\text { armazenados e utilizados de forma } \\
\text { a evitar a contaminação dos } \\
\text { alimentos. }\end{array}$ & I \\
\hline 4.3.3. Retirada freqüente dos resíduos. & $\mathbf{N}$ \\
\hline $\begin{array}{l}\text { 4.3.4. Os alimentos são preparados em } \\
\text { quantidades suficientes, de forma a } \\
\text { evitar sobras. }\end{array}$ & $\mathbf{R}$ \\
\hline $\begin{array}{l}\text { 4.3.5. As sobras são armazenadas } \mathrm{e} \\
\text { reutilizadas de forma adequada. }\end{array}$ & $\mathbf{I}$ \\
\hline $\begin{array}{l}\text { 4.3.6. Os restos de alimentos e resíduos } \\
\text { são acondicionados } \\
\text { adequadamente, cujo destino final é } \\
\text { o lixo. }\end{array}$ & $\mathbf{N}$ \\
\hline
\end{tabular}




\begin{tabular}{|c|c|}
\hline $\begin{array}{ll}\text { 4.4. } & \text { Manipulação dos Alimentos } \\
\text { 4.4.1. } & \text { Desinfecção adequada de } \\
\text { hortifrutigranjeiros. }\end{array}$ & I \\
\hline $\begin{array}{l}\text { 4.4.2. } \\
\text { Descongelamento realizado } \\
\text { corretamente. }\end{array}$ & $\mathbf{N}$ \\
\hline $\begin{array}{l}\text { 4.4.3. Congelamento realizado } \\
\text { corretamente. }\end{array}$ & I \\
\hline $\begin{array}{l}\text { 4.4.4. Não apresenta risco de } \\
\text { contaminação cruzada, entre } \\
\text { alimentos crus e cozidos. }\end{array}$ & $\mathbf{N}$ \\
\hline $\begin{array}{l}\text { 4.4.5. Manipulação adequada durante } \\
\text { preparo e montagem dos pratos. }\end{array}$ & $\mathbf{N}$ \\
\hline $\begin{array}{l}\text { 4.4.6. Existência de lavatórios para } \\
\text { lavagem das mãos com água } \\
\text { corrente. }\end{array}$ & $\mathbf{N}$ \\
\hline $\begin{array}{l}\text { 4.4.7. Lavatórios limpos, dotados de } \\
\text { sabão líquido, escova para as } \\
\text { mãos, desinfetantes e toalhas } \\
\text { claras descartáveis. }\end{array}$ & $\mathbf{N}$ \\
\hline $\begin{array}{ll}\text { 4.5. } & \text { Embalagem/Rotulagem } \\
\text { 4.5.1. } & \text { Embalagens integras, higiênicas e } \\
\text { próprias ao alimento. }\end{array}$ & $\mathbf{N}$ \\
\hline $\begin{array}{l}\text { 4.5.2. Dizeres de rotulagem com } \\
\text { identificação visível e de acordo } \\
\text { com a legislação vigente. }\end{array}$ & $\mathbf{N}$ \\
\hline 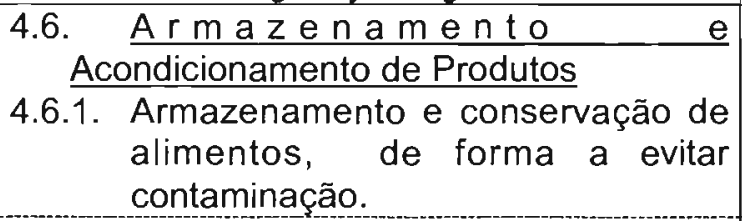 & $\mathbf{N}$ \\
\hline $\begin{array}{l}\text { 4.6.2. Rede de frio para conservação } \\
\text { adequada. }\end{array}$ & 1 \\
\hline $\begin{array}{l}\text { 4.6.3. Existe controle adequado de } \\
\text { temperatura e registro deste } \\
\text { controle. }\end{array}$ & $\mathbf{N}$ \\
\hline $\begin{array}{l}\text { 4.6.4. Alimentos vencidos ou avariados, } \\
\text { quando houver, em local adequado. }\end{array}$ & $\mathbf{N}$ \\
\hline $\begin{array}{l}\text { 4.6.5. Os alimentos preparados não } \\
\text { entram em contato direto com os } \\
\text { alimentos crus. }\end{array}$ & I \\
\hline $\begin{array}{l}\text { 4.7. Distribuição e Exposição de } \\
\text { Alimentos } \\
\text { 4.7.1. Tempo e temperatura adequados } \\
\text { de exposição e conservação de } \\
\text { pratos prontos. }\end{array}$ & 1 \\
\hline 4.7.2. Existe registro dos procedimentos. & $\mathbf{N}$ \\
\hline $\begin{array}{l}\text { 4.7.3. Identificação de pratos prontos } \\
\text { expostos à venda (prazo de } \\
\text { validade, ingredientes). }\end{array}$ & $\mathbf{N}$ \\
\hline $\begin{array}{l}\text { 4.7.4. Os alimentos permanecem } \\
\text { protegidos durante o período de } \\
\text { exposição. }\end{array}$ & $\mathbf{N}$ \\
\hline
\end{tabular}




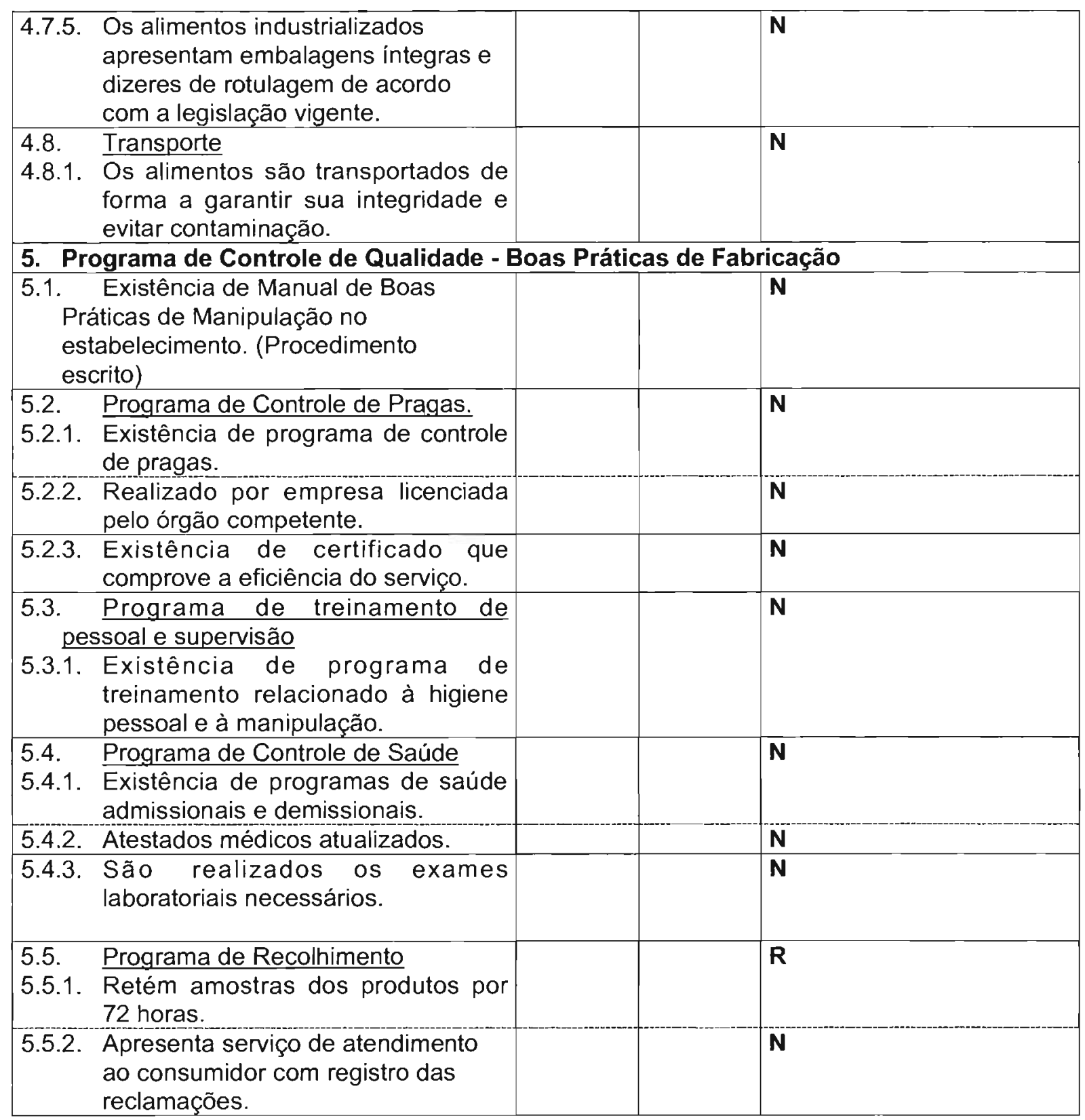

Legenda:

I: Imprescindivel (influi em grau crítico na qualidade ou segurança do produto ou processo)

$\mathrm{N}$ : Necessário (influi em grau menos crítico na qualidade ou segurança do produto ou processo)

R: Recomendável (influi em grau não crítico na qualidade ou segurança do produto ou processo)

Baixo risco: Atende a todos os itens imprescindiveis

Médio risco: Atende parcialmente aos itens imprescindíveis, porém não compromete a segurança do alimento.

Alto risco: Não atende aos itens imprescindiveis e compromete a segurança do alimento. 


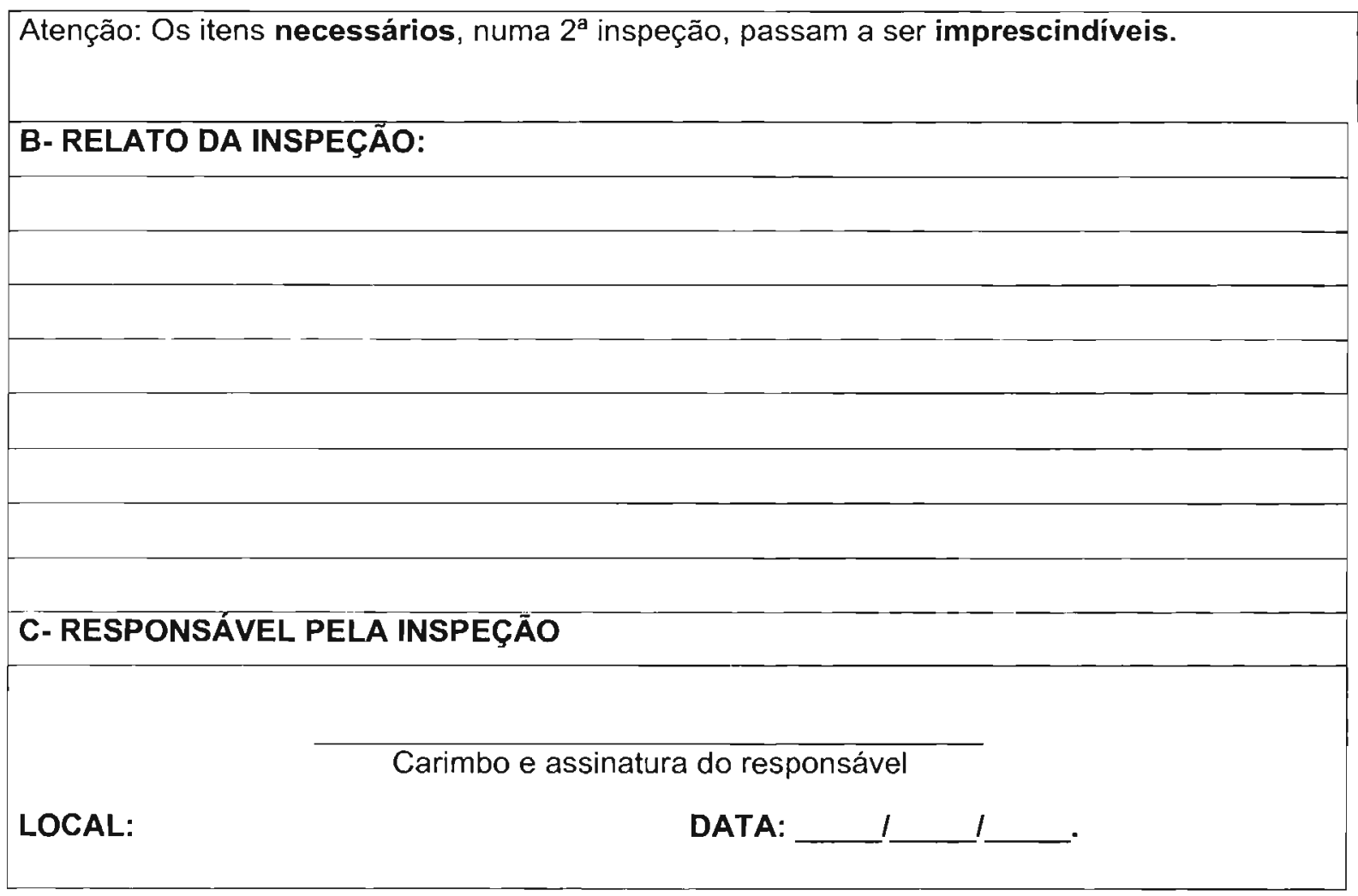




\subsection{2 - ÁNALISES MICROBIOLÓGICAS}

Em oito dias diferentes, procedeu-se a colheita de 32 amostras de alimentos prontos, que foram enviados para um laboratório privado de análise de alimentos, devidamente credenciado pelos Ministérios da Agricultura e da Saúde para realização de análises microbiológicas.

Algumas amostras de alimentos foram colhidas na área de vendas, enquanto outras (lagarto cozido e fatiado) foram colhidas na cozinha durante o fatiamento. As amostras dos alimentos foram colocadas pelo funcionário do estabelecimento em potes descartáveis da própria seção. Em seguida, os potes eram transportados até o laboratório em recipientes de isopor contendo gelo.

Os alimentos selecionados para análise microbiológica foram aqueles que, segundo o Food Establishment Plan Review Guideline (Food and Drug Administration and Conference For Food Protection, 2000), são classificados como "potencialmente perigosos" (potentially hazardous food - PHF), ou seja, aqueles que requerem controle de temperatura porque na forma como se apresentam são capazes de apresentar uma rápida e progressiva multiplicação de microrganismos patogênicos e toxinas e aqueles que têm como matéria-prima produtos de origem animal, tais como ovos e carne crua ou com tratamento térmico insuficiente. 


\section{5 - RESULTADOS E DISCUSSÃO}

\section{1- RESULTADOS DA LISTA DE VERIFICAÇÃO DE BOAS PRATICAS DE} MANIPULAÇÃO EM ESTABELECIMENTOS DE ALIMENTOS

A Figura 12 apresenta os resultados do diagnóstico realizado na rotisseria do supermercado estudado.

\begin{tabular}{|c|c|c|c|}
\hline REQUISITOS/ ITENS & IMPRESCINDÍVEL & NECESSÁRIO & RECOMENDÁVEL \\
\hline $\begin{array}{l}\text { EDIFICAÇṌES E } \\
\text { INSTALAÇÕES } \\
\text { (total do bloco - } 50 \\
\text { itens) }\end{array}$ & $\begin{array}{l}3 \text { atendidos } \\
1 \text { não atendido } \\
1 \text { não aplicável ao } \\
\text { local }\end{array}$ & $\begin{array}{l}27 \text { atendidos } \\
12 \text { não atendidos } \\
5 \text { não aplicáveis ao } \\
\text { estabelecimento }\end{array}$ & 1 não atendido \\
\hline $\begin{array}{l}\text { EQUIPAMENTOS, } \\
\text { MÓVEIS E } \\
\text { UTENSÍLIOS } \\
\text { (total do bloco - } 9 \\
\text { itens) }\end{array}$ & $\begin{array}{l}0 \text { atendido } \\
2 \text { não atendidos }\end{array}$ & $\begin{array}{l}0 \text { atendido } \\
7 \text { não atendidos }\end{array}$ & $-\ldots$ \\
\hline $\begin{array}{l}\text { MANIPULADORES } \\
\text { (total do bloco - } 6 \\
\text { itens) }\end{array}$ & $\begin{array}{l}1 \text { atendido } \\
1 \text { não atendido }\end{array}$ & $\begin{array}{l}1 \text { atendido } \\
3 \text { não atendidos }\end{array}$ & ----- \\
\hline $\begin{array}{l}\text { FLUXO DE } \\
\text { PRODUÇÃo } \\
\text { (total do bloco - } 39 \\
\text { itens) }\end{array}$ & $\begin{array}{l}1 \text { atendido } \\
7 \text { não atendidos }\end{array}$ & $\begin{array}{l}12 \text { atendidos } \\
17 \text { não atendidos } \\
1 \text { não aplicável no } \\
\text { estabelecimento }\end{array}$ & 1 não atendido \\
\hline $\begin{array}{l}\text { PROGRAMA DE } \\
\text { CONTROLE DE } \\
\text { QUALIDADE } \\
\text { (total do bloco- } 10 \\
\text { itens) }\end{array}$ & ------- & $\begin{array}{l}6 \text { atendidos } \\
3 \text { não atendidos }\end{array}$ & 1 não atendido \\
\hline
\end{tabular}

Figura 12: Resultados da Lista de verificação das Boas Praticas de Manipulação em Estabelecimento da área de Alimentos (PMSP/SMS). 


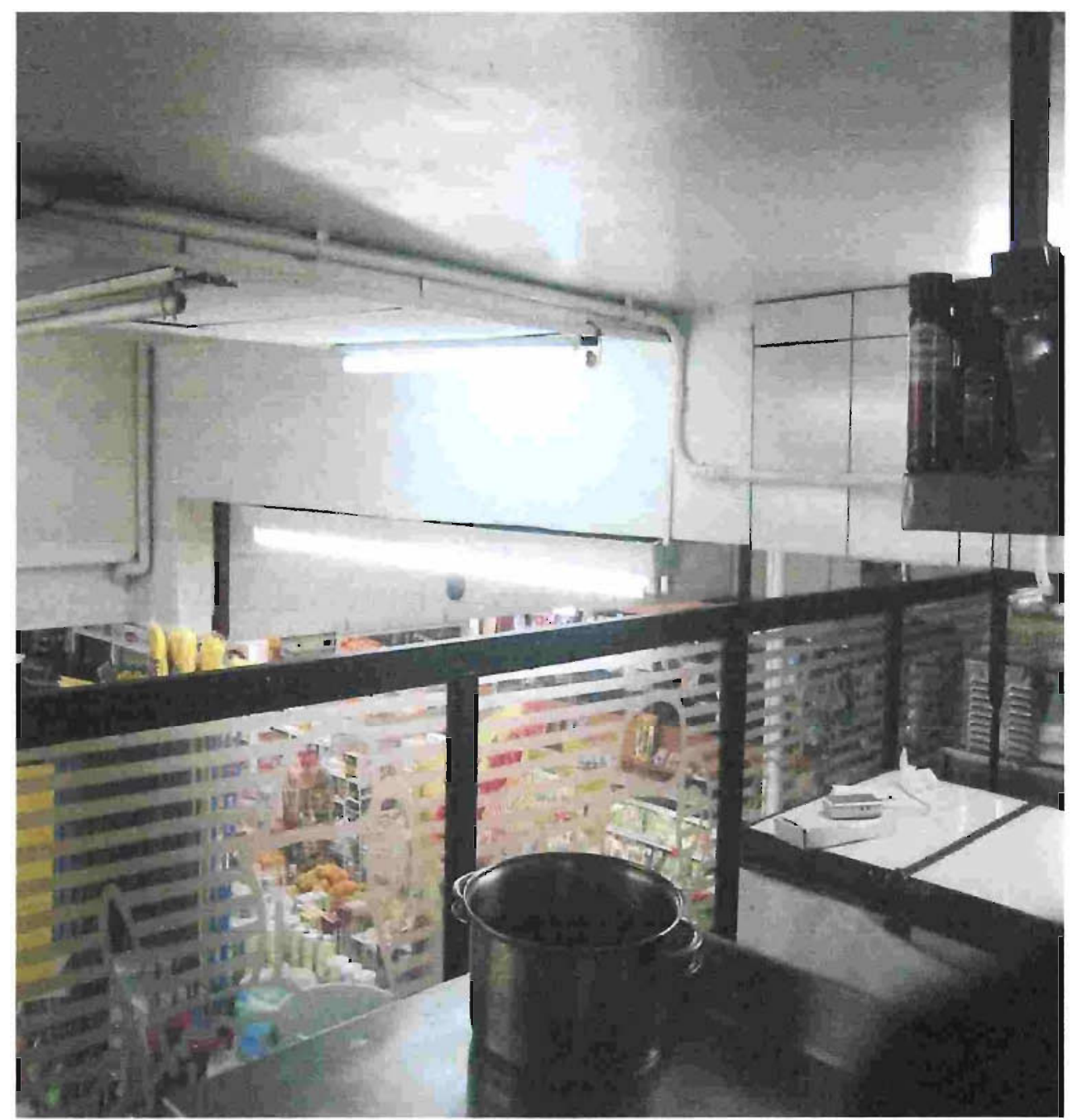

Figura 13: Localização da cozinha da rotisseria 


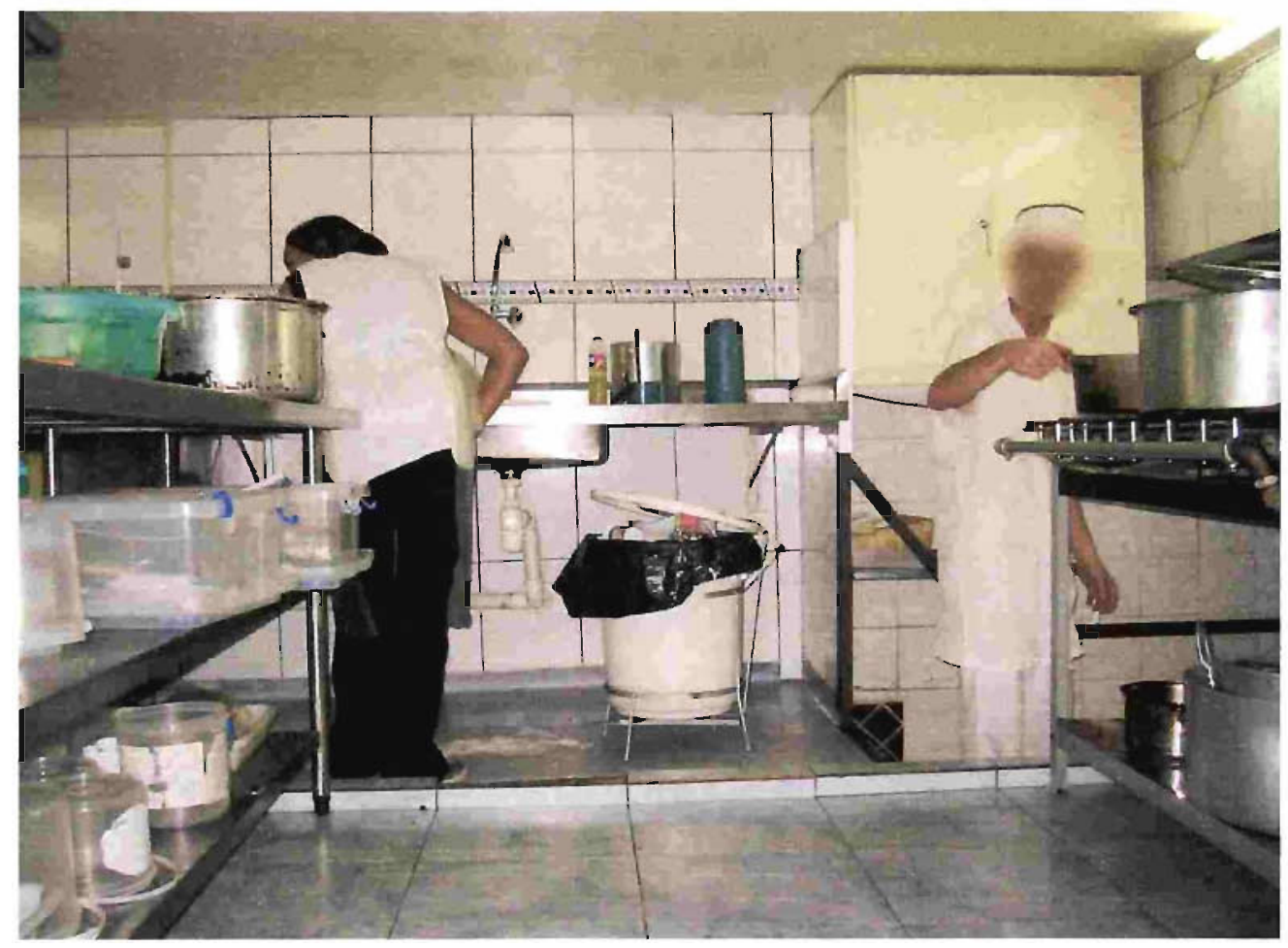

Figura 14 : Vista da cozinha da rotisseria e alguns equipamentos

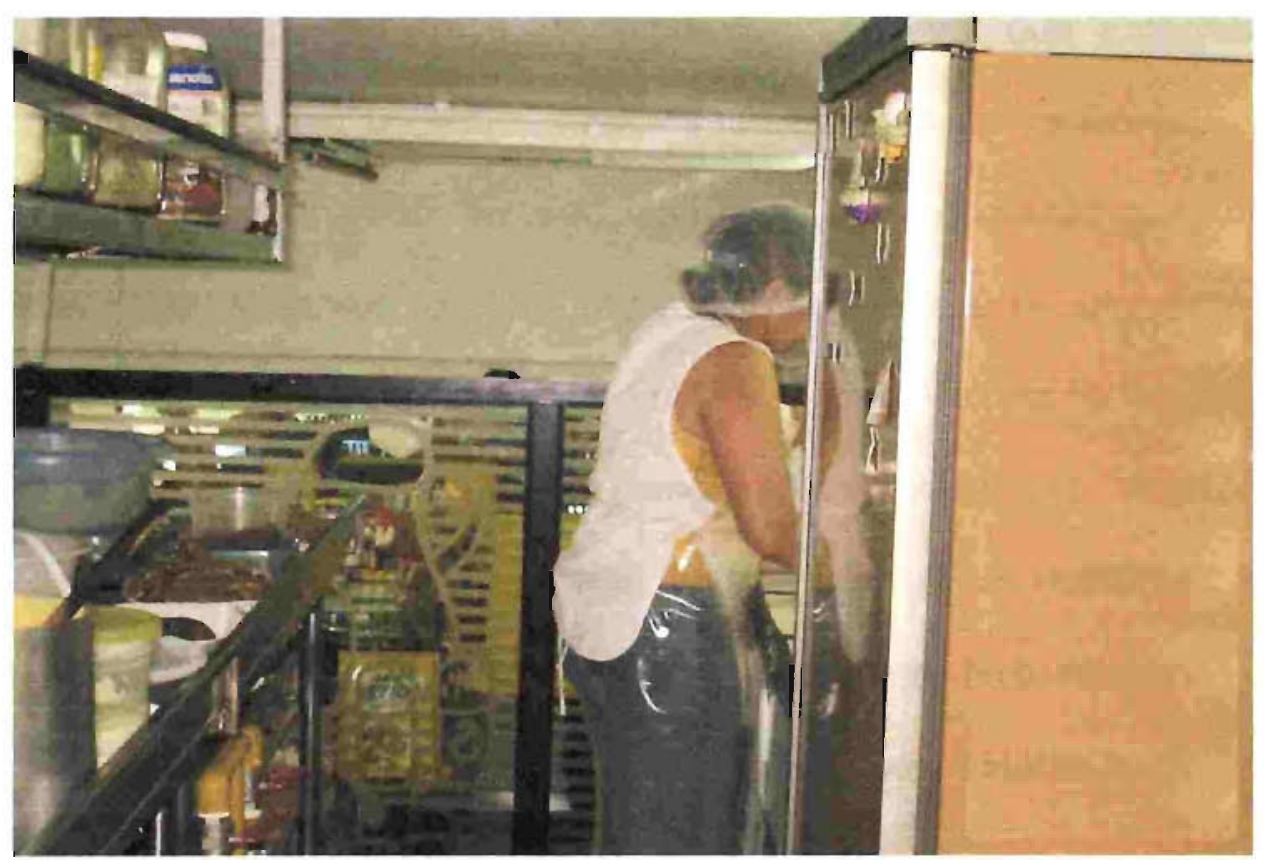

Figura 15: Foto da cozinha da rotisseria em supermercado com destaque para mesa de apoio e geladeira. 


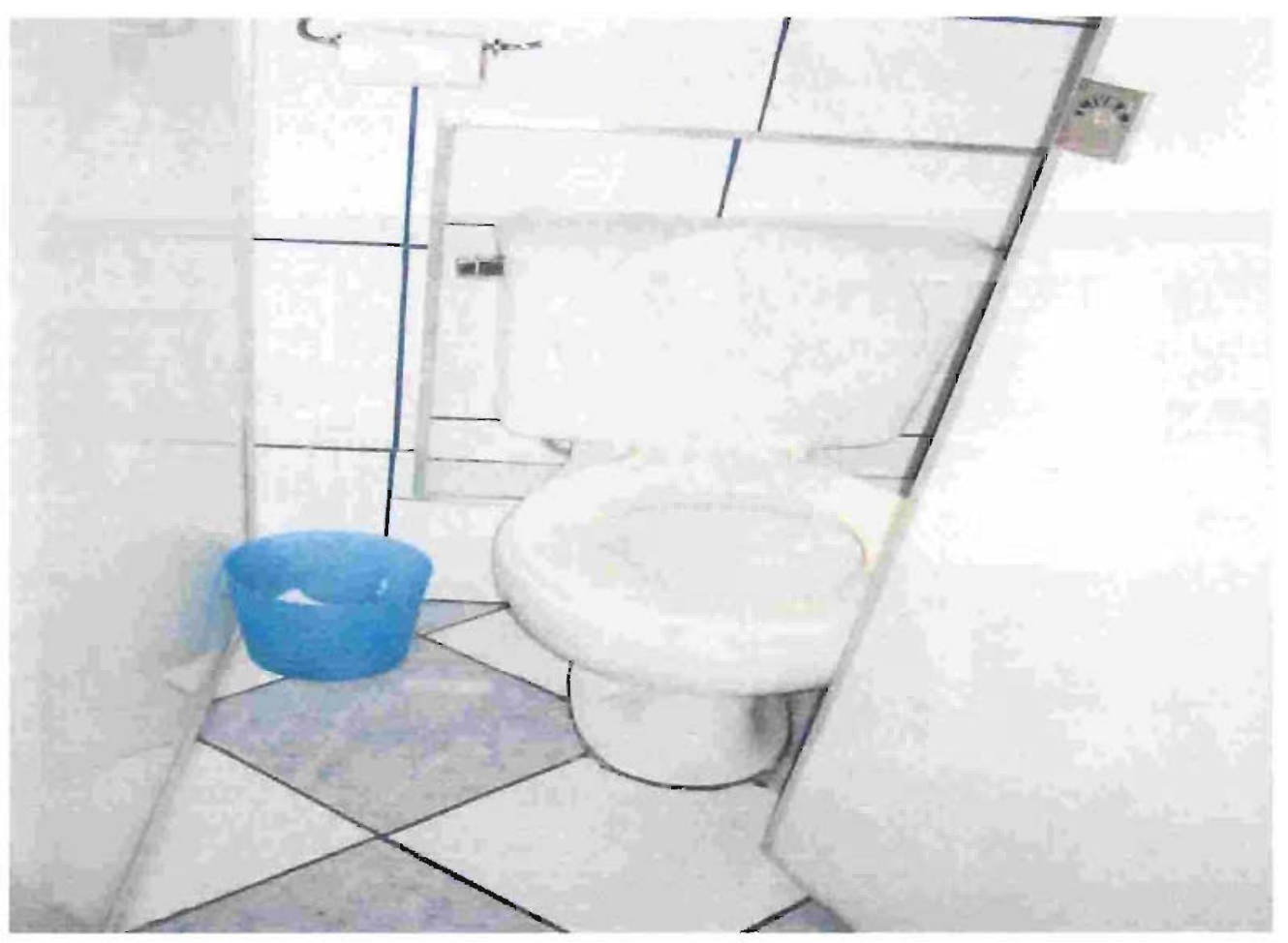

Figura 16: Foto de sanitärio feminino .

Conforme as figuras 13,14 e 15, é possivel observar que a cozinha da rotisseria encontrava-se em um local improvisado, em um mezanino localizado acima de outras seções do supermercado. Não havia uma separação completa da área de preparo dos alimentos (cozinha) do restante da loja e as luminárias não estavam protegidas conforme recomenda a Portaria 2.535. A altura da cozinha era inferior a 2,70m, não permintindo haver o completo conforto térmico, ventilação e renovação de ar necessários. O local não apresentava áreas distintas para o preparo de alimentos e para a higienização de utensílios. Nos sanitários para manipuladores (figura16), as portas não eram dotadas de fechamento automático e a lixeira não possuia tampa, conforme recomenda a Portaria 2.535. 


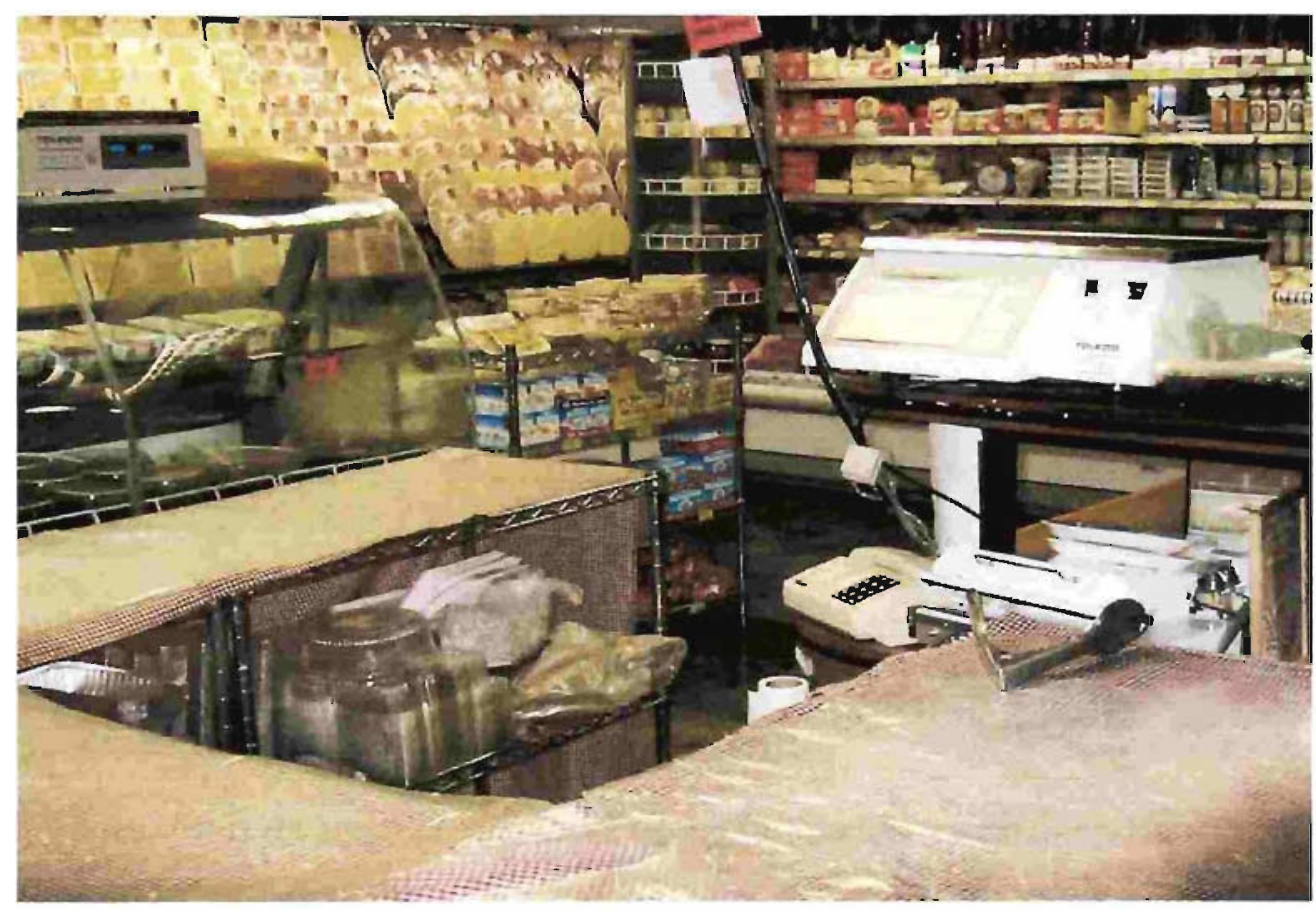

Figura 17: Foto da área de vendas de alimentos prontos antes do inicio do serviço.

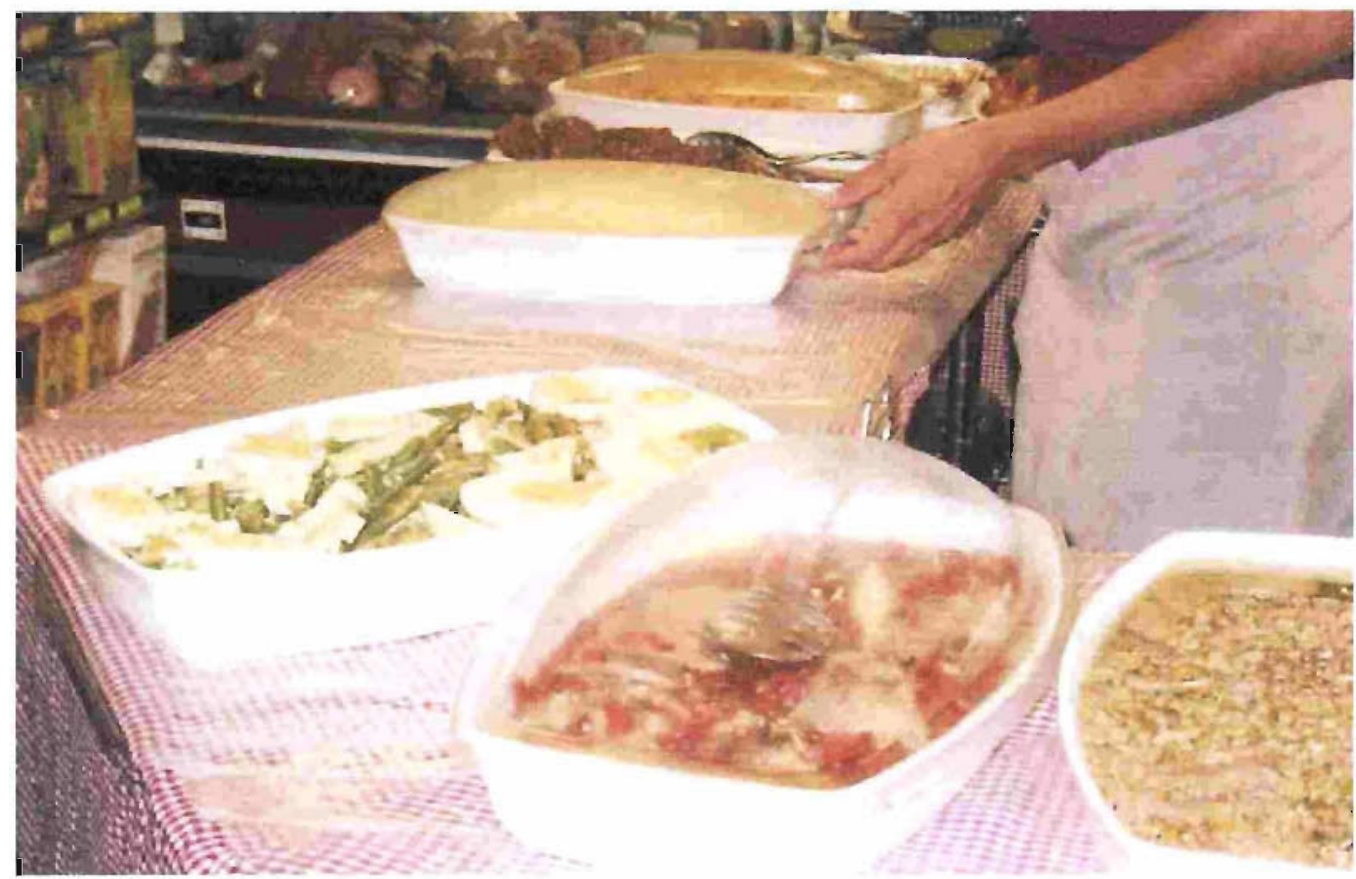

Figura 18: Foto da área de vendas de alimentos da rotisseria no momento da arrumação das travessas 


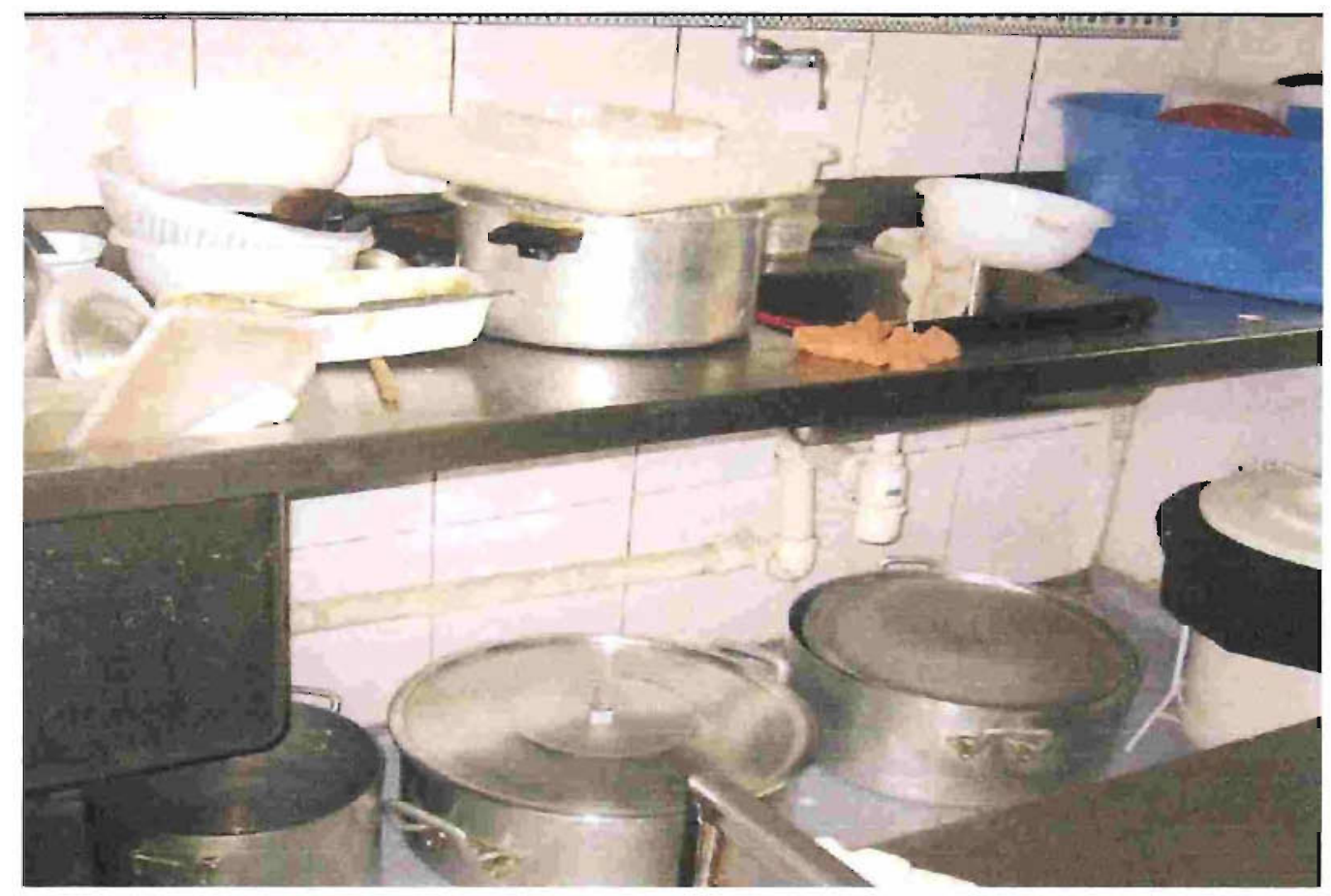

Figura 19: Foto de utensilios e local de higienização na cozinha da rotisseria.

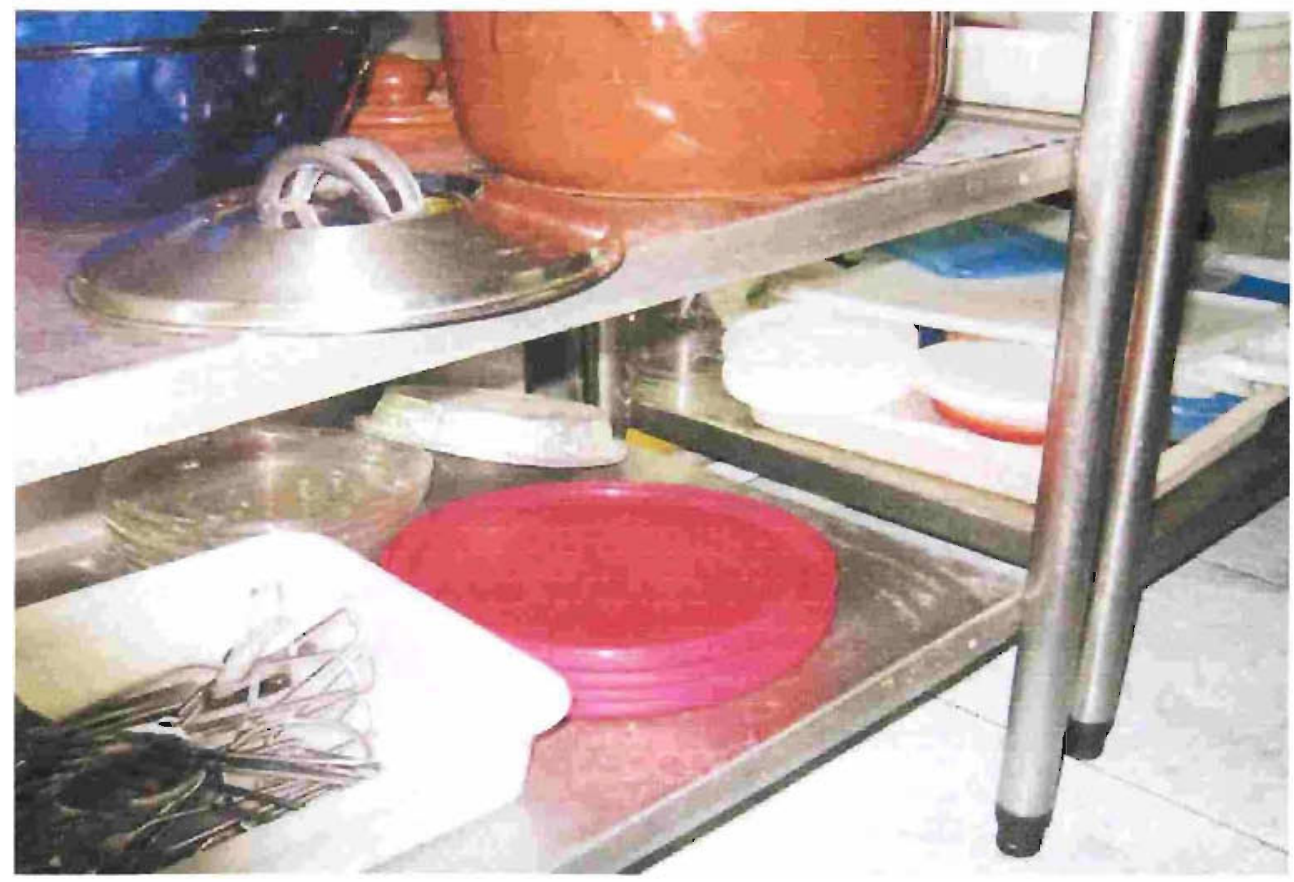

Figura 20: Foto de móveis e utensílios da cozinha da rotisseria. 


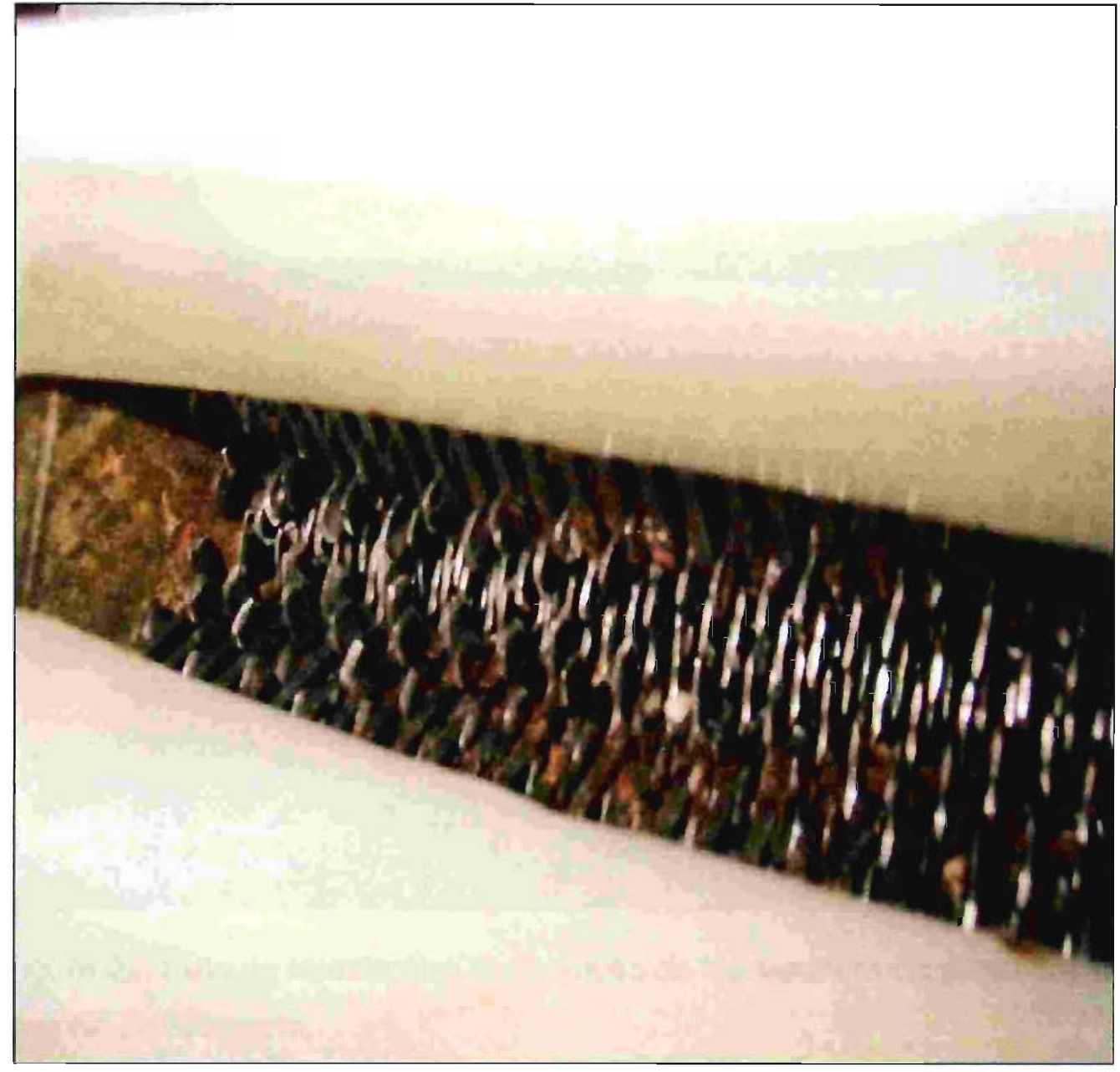

Figura 21: Foto de equipamento - amaciador de carne. 


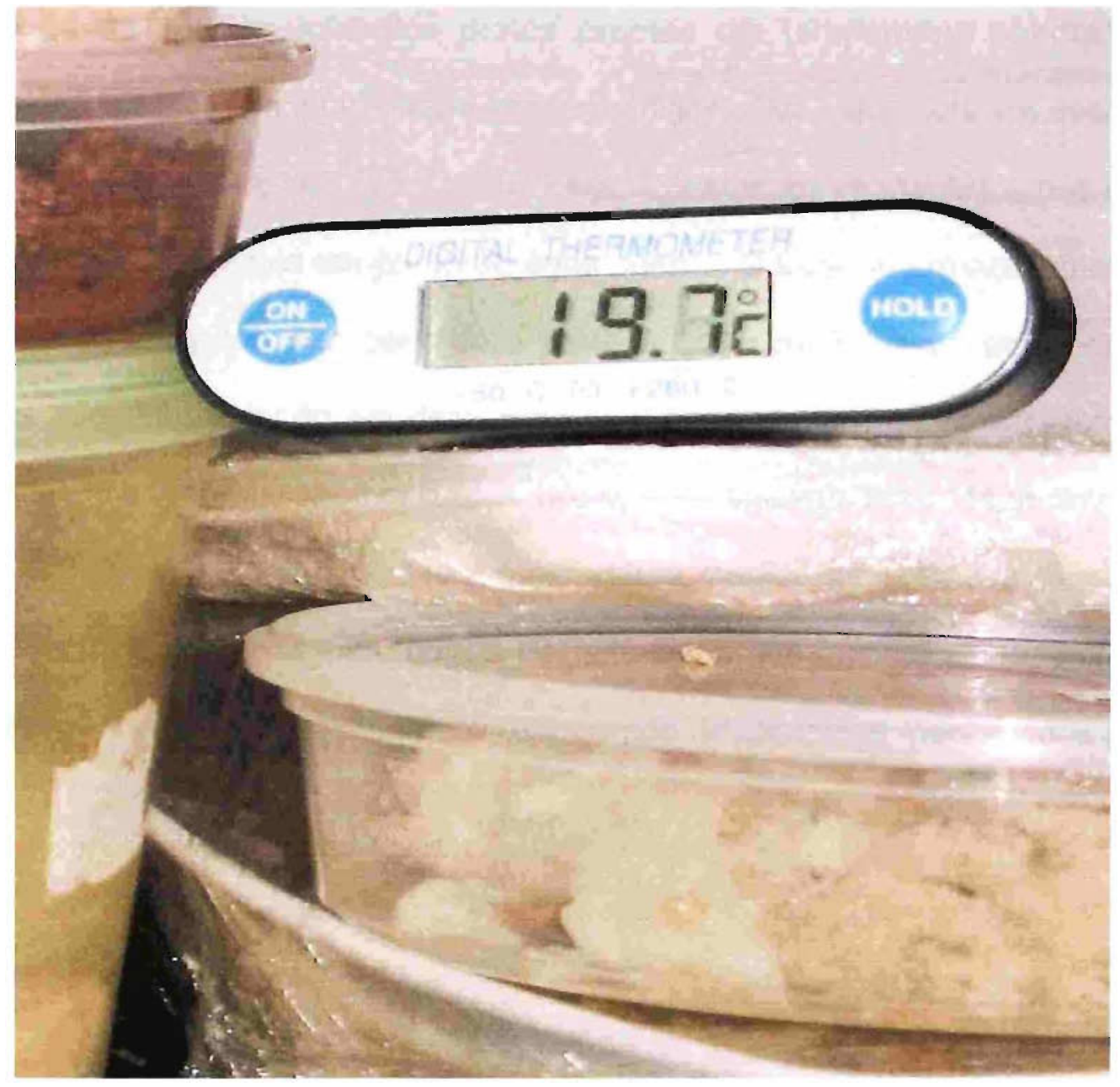

Figura 22: Foto de termômetro na medição de temperatura da geladeira da cozinha da rotisseria. 
O local onde os alimentos eram expostos à venda para o consumidor foi adaptado na seção de frios e laticinios (figura 17). Não havia equipamento (balcão térmico) para a exposição dos pratos prontos em temperatura controlada. A exposição era feita em temperatura ambiente (figura 18), o que está em desacordo com a Portaria Municipal 2.535. O local para higienização de utensílios não estava adequado e não possuia um ponto de água quente. $O$ local de armazenamento de utensilios higenizados não permitia a proteção de contaminação pelo ambiente (figuras 19 e 20), estando em desacordo com a legislação. Alguns equipamentos não estavam corretamente higenizados, isto é, apresentavam residuos de suijidades (figura 21). Em algumas ocasiões a temperatura medida na geladeira da cozinha $\left(19,7^{\circ} \mathrm{C}\right)$ estava em desacordo com a Portaria 2.535 que recomenda temperaturas inferiores a $8^{\circ} \mathrm{C}$ para armazenamento refrigerado de alimentos manipulados (figura 22). 


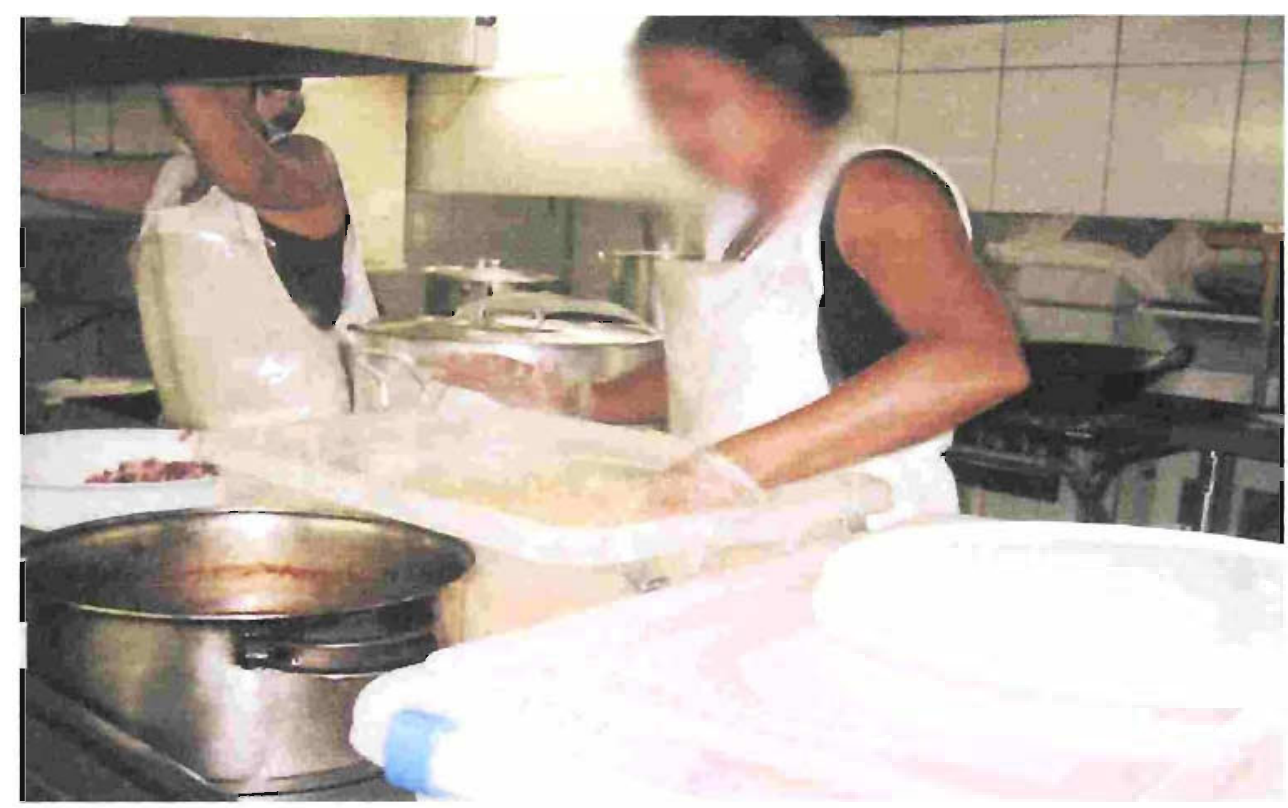

Figura 23: Foto de funcionários da cozinha da rotisseria preparando maionese de legumes.

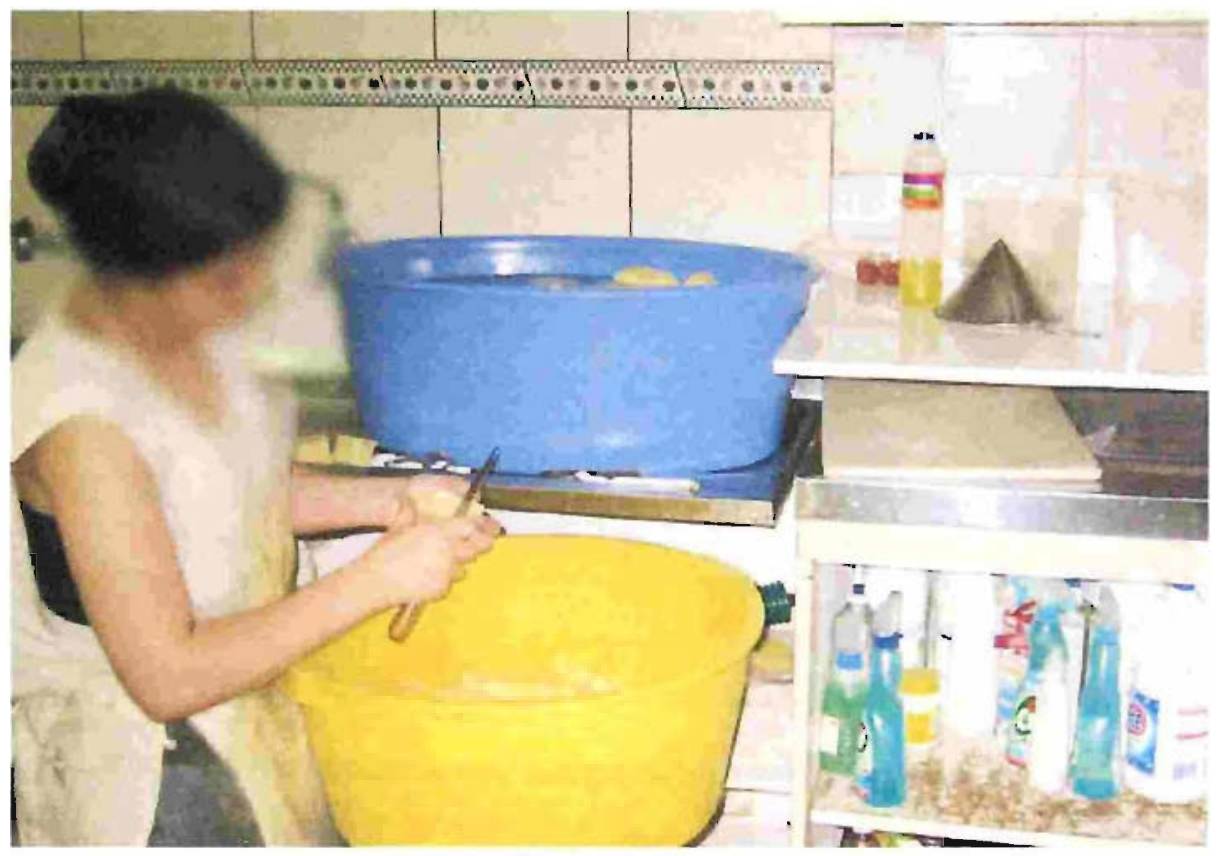

Figura 24: Foto de funcionária da cozinha da rotisseria cortando legumes.

Os funcionários nằo tinham uniformizaçằo completa de cor clara, a ser usada apenas nas dependências internas do estabelecimento, conforme exigido na legislação em vigor (figuras 23 e 24). 


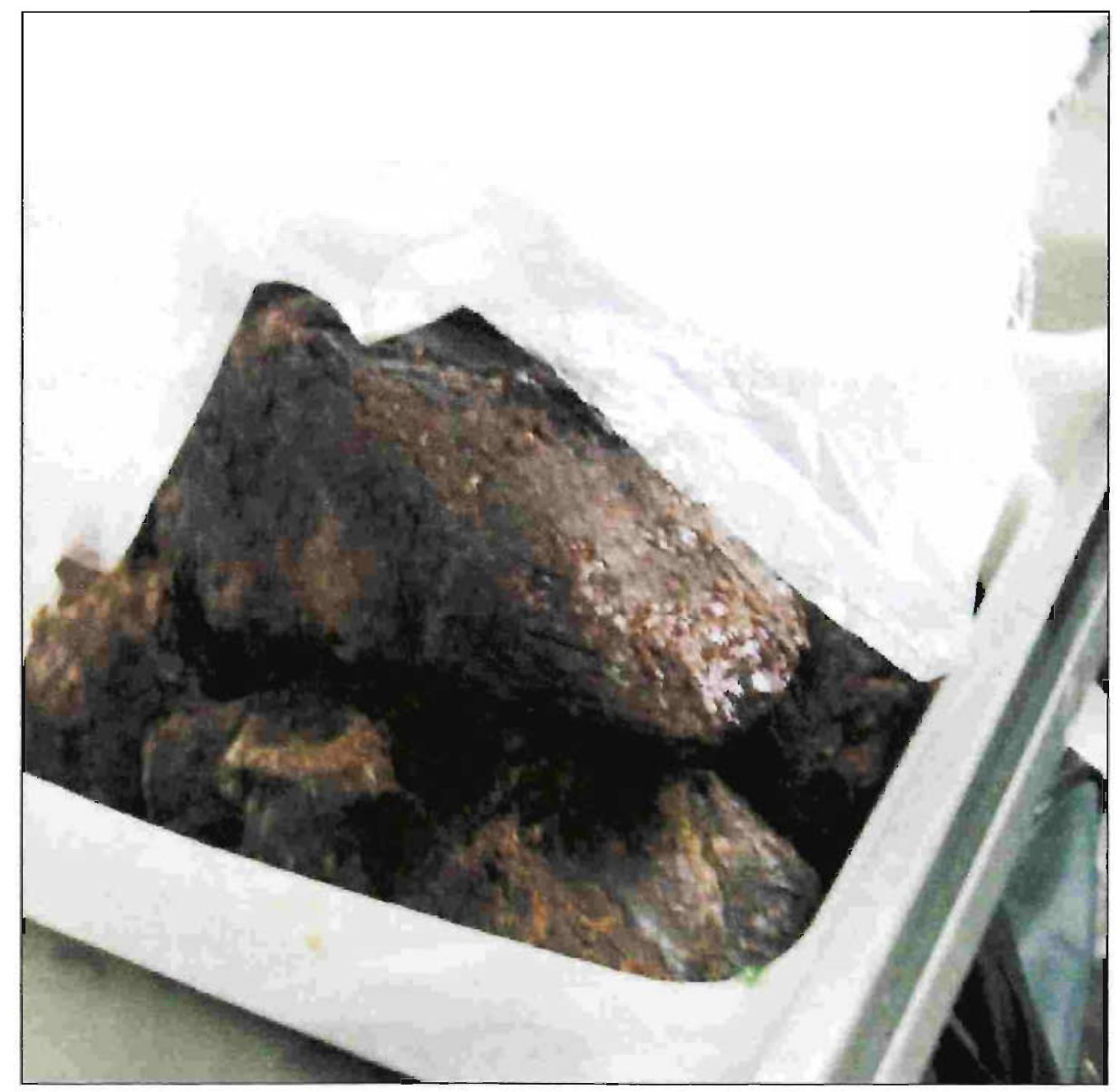

Figura 25: Foto de carne assada em temperatura ambiente na cozinha da rotisseria. 


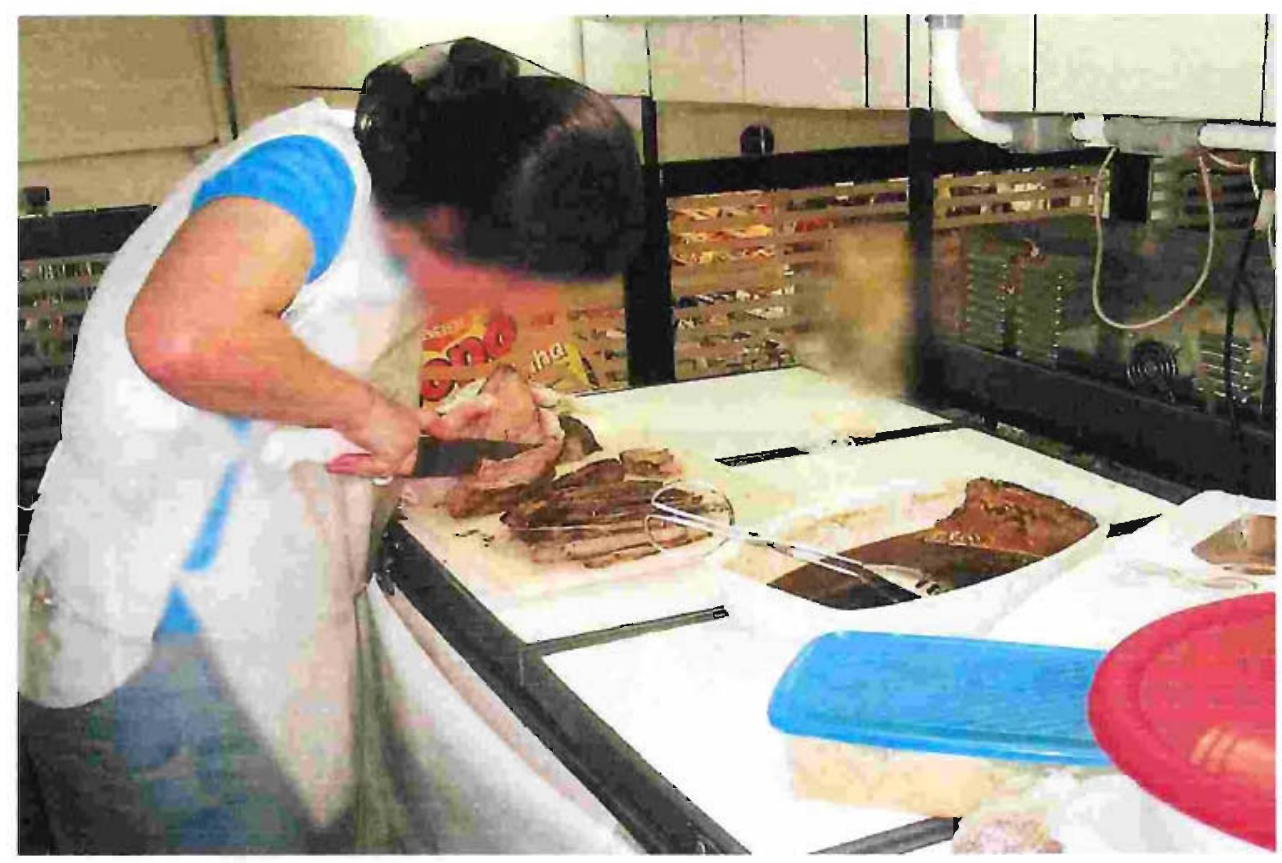

Figura 26: Foto de funcionária cortando carne assada para expor na área de vendas.

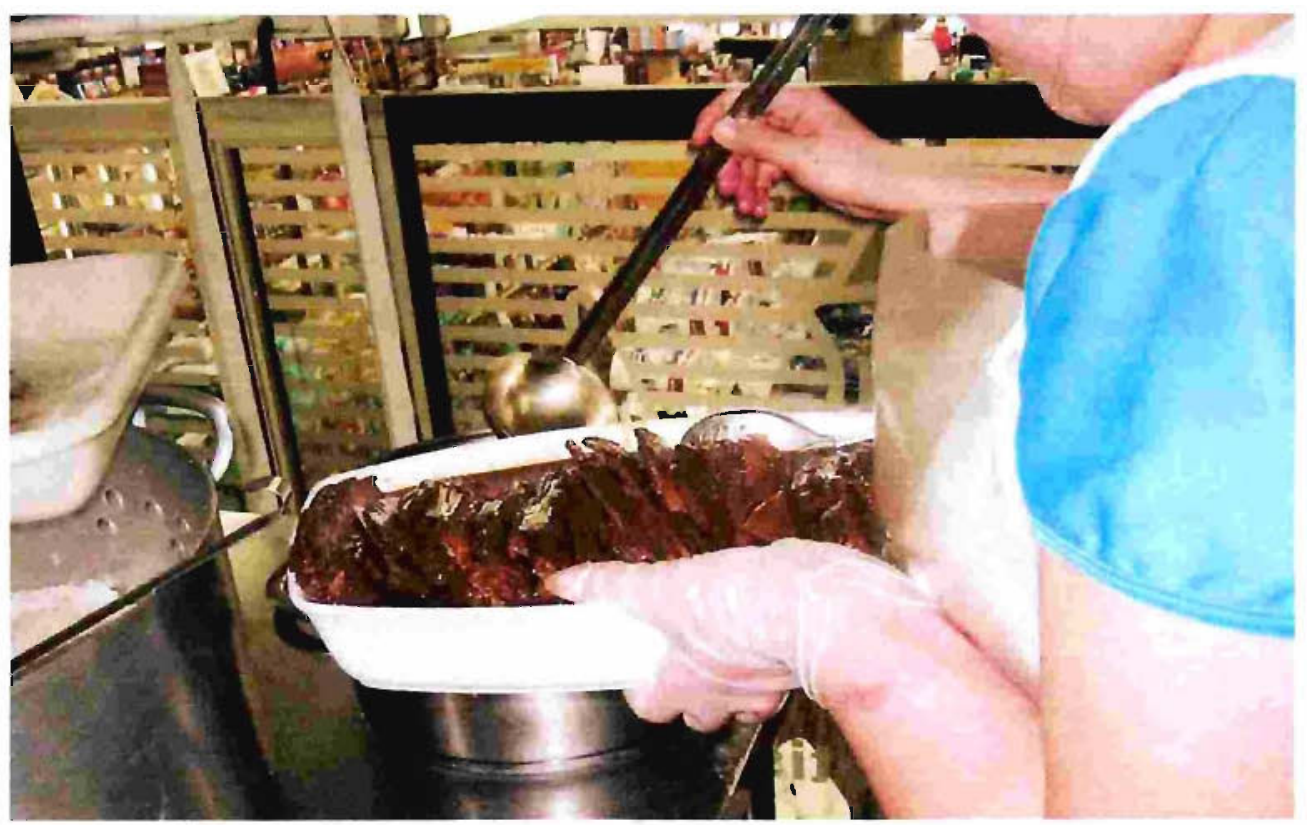

Figura 27: Foto de funcionária da cozinha acrescentando molho à carne assada para expor na área de vendas. 


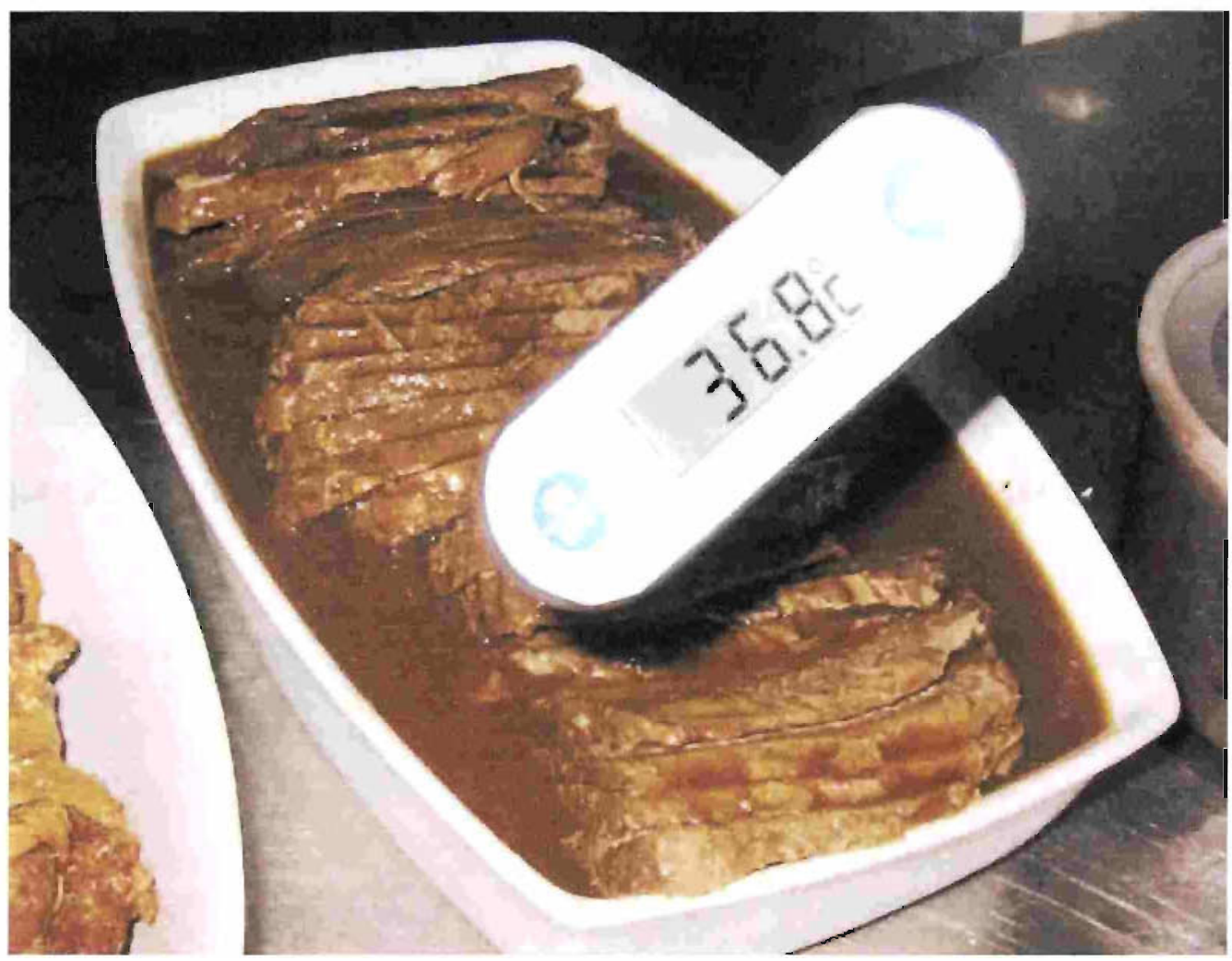

Figura 28: Foto da medição de temperatura da carne assada com molho para exposição à venda. 


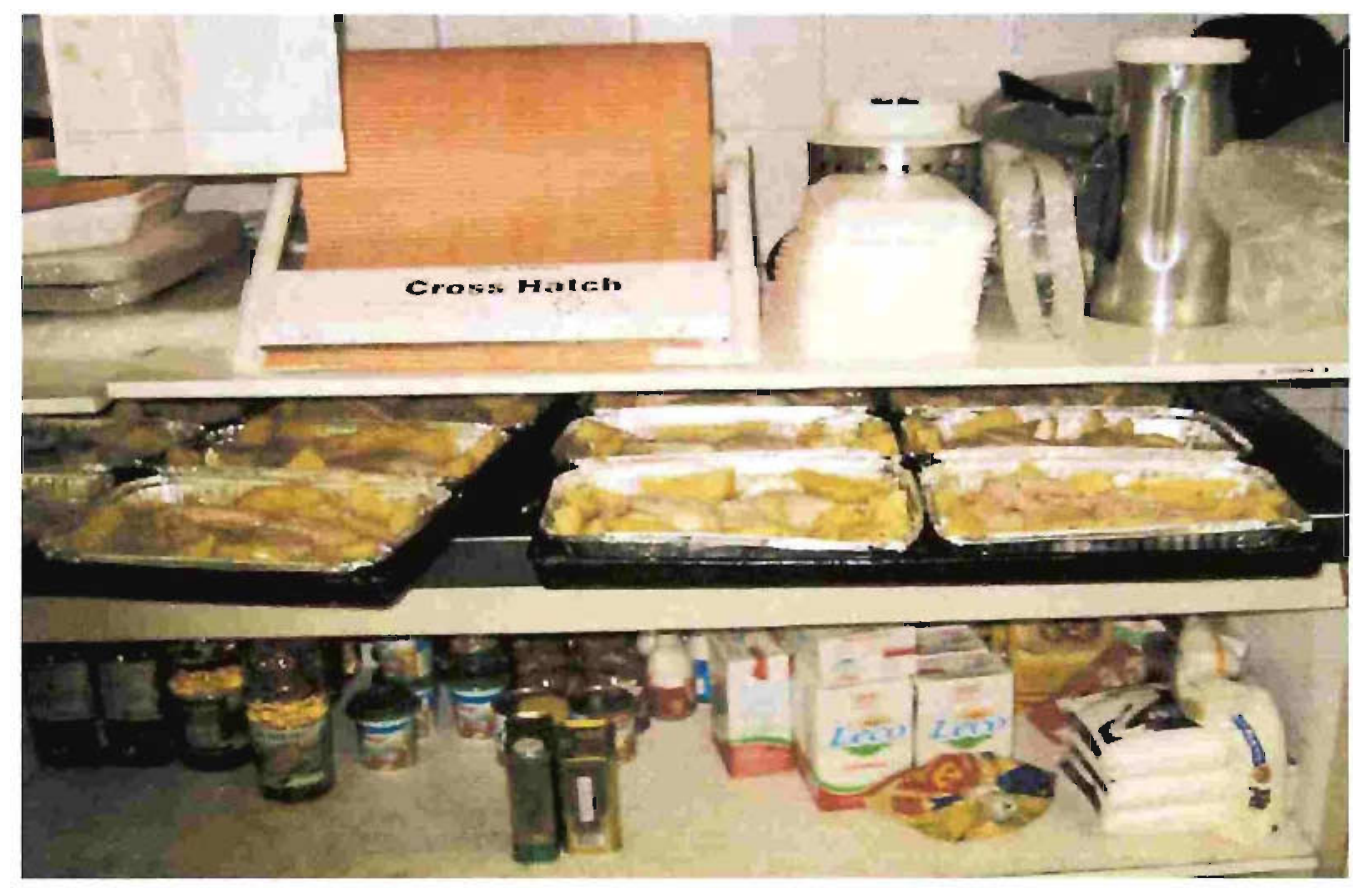

Figura 29: Foto de produto pronto frango assado com batatas para exposição na área de vendas da rotisseria.

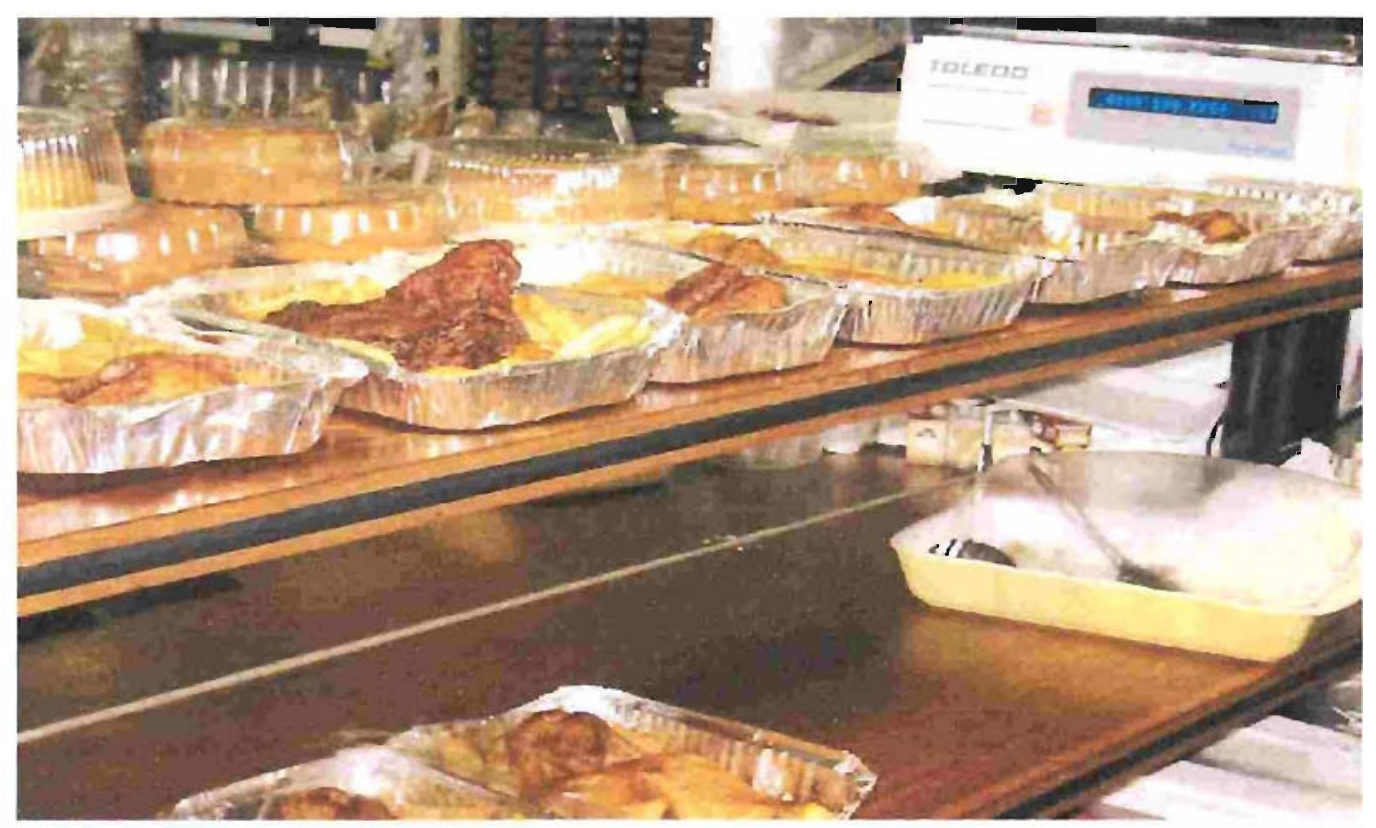

Figura 30: Foto de frango assado exposto a venda na seção de rotisseria. 


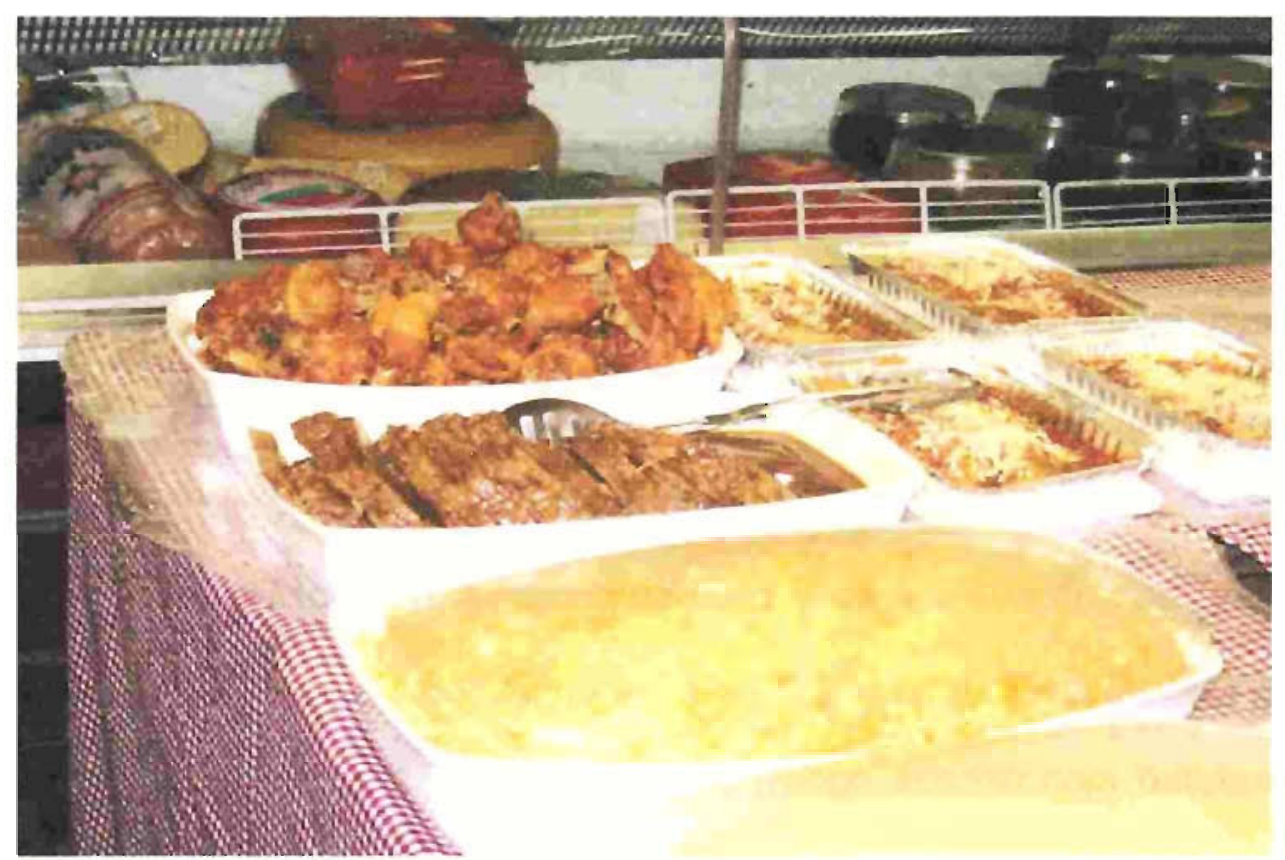

Figura 31: Foto da área de vendas de alimentos da rotisseria com destaque para carne assada com molho ferrugem, frango a passarinho e lasanha.

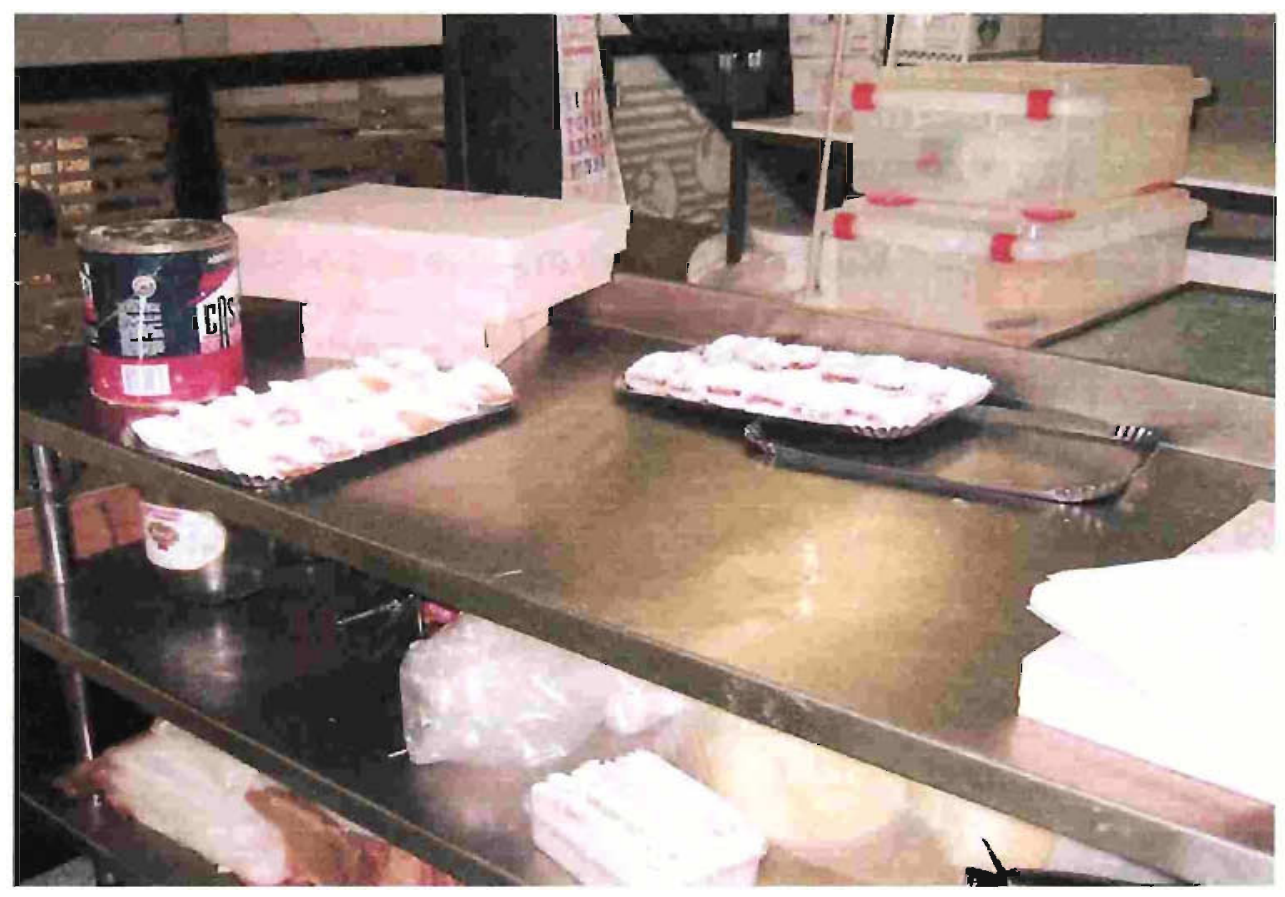

Figura 32: Foto da cozinha da rotisseria em supermercado, com destaque para mesa de apoio de embalagem. 
O preparo da carne assada não atendia a recomendação da legislação porque as peças de carne cozida não passavam por reaquecimento numa temperatura superior a $70^{\circ} \mathrm{C}$ antes de serem expostas a venda. A carne que estava em temperatura ambiente era fatiada, arrumada em vasilha de louça e recebia o molho quente atingindo a temperatura de $36,8^{\circ} \mathrm{C}$ (figuras $25,26,27$ e 28). Esta preparação permanecia exposta à venda em temperatura ambiente e, dessa forma, estava em desacordo com o recomendado pela legislação, ou seja, para manutenção a $65^{\circ} \mathrm{C}$ ou mais por 12 horas, a $60^{\circ} \mathrm{C}$ por no máximo 6 horas e abaixo de $60^{\circ} \mathrm{C}$ por no máximo 1 hora. $\mathrm{O}$ produto frango assado com batatas estava exposto sem proteção da contaminação ambiente (figuras 29, 30 e 31), portanto também está em desacordo com a legislação vigente. Segundo a Portaria 2.535, o local de embalagem de alimentos prontos deve apresentar as mesmas características de organização e higienização das demais áreas de preparo de alimentos. Porém, conforme mostra a figura 32, na mesa de embalagem de doces havia uma lata de cola, o que está em desacordo com a legislação.

A empresa não tinha o Manual de Boas Práticas de Manipulação nem um Programa de Treinamento para Manipuladores sobre higiene pessoal e de alimentos conforme recomenda a legislação. Por outro lado, a empresa tinha um Programa CIP - Controle Integrado de Pragas, realizado por empresa licenciada nos orgãos competentes atendendo a recomendação da legislação em vigor. 


\section{2 - RESULTADOS DE ANÁLISES MICROBIOLÓGICAS}

Os resultados das análises microbiológicas são apresentados nas tabelas 2 a 9 . Tabela 2: Resultado de Análise Microbiológica de Alimentos Preparados e expostos à Venda no dia 08/12/2003

\section{PRODUTOS}

\begin{tabular}{|c|c|c|c|c|}
\hline DETERMINAÇÃO & $\begin{array}{l}\text { Carne assada } \\
\text { com molho }\end{array}$ & $\begin{array}{l}\text { Lagarto com } \\
\text { aliche }\end{array}$ & $\begin{array}{l}\text { Lagarto a } \\
\text { escabeche }\end{array}$ & $\begin{array}{l}\text { Batata } \\
\text { aperitivo }\end{array}$ \\
\hline Coliformes a $35^{\circ} \mathrm{C}$ & $240 \mathrm{NMP} / \mathrm{g}$ & $>1100 \mathrm{NMP} / \mathrm{g}$ & $>1.100 \mathrm{NMP} / \mathrm{g}$ & $<3 \mathrm{NMP} / \mathrm{g}$ \\
\hline Coliformes a $45^{\circ} \mathrm{C}$ & 3,6 NMP/g & $75 \mathrm{NMP} / \mathrm{g}$ & $15 \mathrm{NMP} / \mathrm{g}$ & $<3 \mathrm{NMP} / \mathrm{g}$ \\
\hline $\begin{array}{l}\text { Estafilococos } \\
\text { coagulase } \\
\text { positiva }\end{array}$ & $<100 \mathrm{UFC} / \mathrm{g}$ & $<100 \mathrm{UFC} / \mathrm{g}$ & $<100 \mathrm{UFC} / \mathrm{g}$ & $<100 \mathrm{UFC} / \mathrm{g}$ \\
\hline Bacillus cereus & $<100$ UFC/g & $<100 \mathrm{UFC} / \mathrm{g}$ & $<100$ UFC/g & $<100 \mathrm{UFC} / \mathrm{g}$ \\
\hline $\begin{array}{l}\text { Clostridios sulfito } \\
\text { redutores a } 46^{\circ} \mathrm{C}\end{array}$ & $<100 \mathrm{UFC} / \mathrm{g}$ & $<100 \mathrm{UFC} / \mathrm{g}$ & $<100 \mathrm{UFC} / \mathrm{g}$ & não realizado \\
\hline Salmonella sp & Ausente $/ 25 \mathrm{~g}$ & Ausente $/ 25 \mathrm{~g}$ & Ausente/25 g & Ausente $/ 25 \mathrm{~g}$ \\
\hline
\end{tabular}


TABELA 3: Resultado de Análise Microbiológica de Alimentos Preparados e expostos à Venda no dia 09/12/2003

\section{PRODUTOS}

\begin{tabular}{|c|c|c|c|c|}
\hline DETERMINAÇÃO & $\begin{array}{l}\text { Carne assada } \\
\text { com molho }\end{array}$ & $\begin{array}{l}\text { Lagarto com } \\
\text { aliche }\end{array}$ & $\begin{array}{l}\text { Lagarto a } \\
\text { escabeche }\end{array}$ & Batata aperitivo \\
\hline Coliformes a $35^{\circ} \mathrm{C}$ & $>1.100 \mathrm{NMP} / \mathrm{g}$ & $>1.100 \mathrm{NMP} / \mathrm{g}$ & $>1.100 \mathrm{NMP} / \mathrm{g}$ & $7,3 \mathrm{NMP} / \mathrm{g}$ \\
\hline Coliformes a $45^{\circ} \mathrm{C}$ & $43 \mathrm{NMP} / \mathrm{g}$ & $<3 \mathrm{NMP} / \mathrm{g}$ & $43 \mathrm{NMP} / \mathrm{g}$ & $<3 \mathrm{NMP} / \mathrm{g}$ \\
\hline $\begin{array}{l}\text { Estafilococos } \\
\text { coagulase positiva }\end{array}$ & $<100$ UFC/g & $<100$ UFC/g & $<100$ UFC/g & $<100$ UFC/g \\
\hline Bacillus cereus & $<100$ UFC/g & $<100$ UFC/g & $<100$ UFC/g & $<100$ UFC/g \\
\hline $\begin{array}{l}\text { Clostridios sulfito } \\
\text { redutores a } 46^{\circ} \mathrm{C}\end{array}$ & $<100$ UFC/g & $<100$ UFC/g & $<100$ UFC/g & não realizado \\
\hline Salmonella sp & Ausente $/ 25 \mathrm{~g}$ & Ausente $/ 25 \mathrm{~g}$ & Ausente $/ 25 \mathrm{~g}$ & Ausente $/ 25 \mathrm{~g}$ \\
\hline
\end{tabular}

TABELA 4: Resultado de Análise Microbiológica de Alimentos Preparados e expostos à Venda no dia $15 / 12 / 2003$

\section{PRODUTOS}

\begin{tabular}{|c|c|c|c|c|}
\hline DETERMINAÇÃO & $\begin{array}{l}\text { Carne assada } \\
\text { com molho }\end{array}$ & $\begin{array}{l}\text { Lagarto com } \\
\text { aliche }\end{array}$ & $\begin{array}{l}\text { Lagarto a } \\
\text { escabeche }\end{array}$ & $\begin{array}{l}\text { Molho de } \\
\text { Carne }\end{array}$ \\
\hline Coliformes a $35^{\circ} \mathrm{C}$ & $460 \mathrm{NMP} / \mathrm{g}$ & $>1.100 \mathrm{NMP} / \mathrm{g}$ & $1.100 \mathrm{NMP} / \mathrm{g}$ & $1,5 \mathrm{NMP} / \mathrm{g}$ \\
\hline Coliformes a $45^{\circ} \mathrm{C}$ & $7,2 \mathrm{NMP} / \mathrm{g}$ & $15 \mathrm{NMP} / \mathrm{g}$ & $23 \mathrm{NMP} / \mathrm{g}$ & $0,36 \mathrm{NMP} / \mathrm{g}$ \\
\hline $\begin{array}{l}\text { Estafilococos } \\
\text { coagulase } \\
\text { positiva }\end{array}$ & $<100$ UFC/g & $<100$ UFC/g & $<100$ UFC/g & $<100$ UFC/g \\
\hline Bacillus cereus & $<100$ UFC/g & $<100$ UFC/g & $<100$ UFC/g & $<100$ UFC/g \\
\hline $\begin{array}{l}\text { Clostridios sulfito } \\
\text { redutores a } 46^{\circ} \mathrm{C}\end{array}$ & $<100$ UFC/g & $<100 \mathrm{UFC} / \mathrm{g}$ & $<100$ UFC/g & $<10$ UFC/g \\
\hline Salmonella sp & Ausente $/ 25 \mathrm{~g}$ & Ausente $/ 25 \mathrm{~g}$ & Ausente $/ 25 \mathrm{~g}$ & Ausente $/ 25 \mathrm{~g}$ \\
\hline
\end{tabular}


TABELA 5: Resultado de Análise Microbiológica de Alimentos Preparados e Expostos à venda no dia 17/12/2003

\section{PRODUTOS}

\begin{tabular}{|c|c|c|c|c|}
\hline DETERMINAÇÃO & $\begin{array}{l}\text { Carne assada } \\
\text { com molho }\end{array}$ & $\begin{array}{l}\text { Farofa de } \\
\text { Carne }\end{array}$ & $\begin{array}{l}\text { Maionese de } \\
\text { legumes }\end{array}$ & $\begin{array}{l}\text { Lagarto Cozido } \\
\text { (fatiado) }\end{array}$ \\
\hline Coliformes a $35^{\circ} \mathrm{C}$ & $1.100 \mathrm{NMP} / \mathrm{g}$ & $>1.100 \mathrm{NMP} / \mathrm{g}$ & $>1.100 \mathrm{NMP} / \mathrm{g}$ & $>1.100 \mathrm{NMP} / \mathrm{g}$ \\
\hline Coliformes a $45^{\circ} \mathrm{C}$ & $15 \mathrm{NMP} / \mathrm{g}$ & $36 \mathrm{NMP} / \mathrm{g}$ & $93 \mathrm{NMP} / \mathrm{g}$ & $75 \mathrm{NMP} / \mathrm{g}$ \\
\hline $\begin{array}{l}\text { Estafilococos } \\
\text { coagulase } \\
\text { positiva }\end{array}$ & $<100 \mathrm{UFC} / \mathrm{g}$ & $<100$ UFC/g & $<100 /$ UFC & $<100$ UFC/g \\
\hline Bacillus cereus & $<100 \mathrm{UFC} / \mathrm{g}$ & $<100$ UFC/g & não realizado & 100 UFC/g \\
\hline $\begin{array}{l}\text { Clostridios sulfito } \\
\text { redutores a } 46^{\circ} \mathrm{C}\end{array}$ & $<100$ UFC/g & $<100$ UFC/g & não realizado & $<100$ UFC/g \\
\hline Salmonella sp & Ausente/25 g & Ausente/25 g & Ausente/25 g & Ausente/25 g \\
\hline
\end{tabular}

TABELA 6: Resultado de Análise Microbiológica de Alimentos Preparados e Expostos à Venda no dia 22/01/2004

\begin{tabular}{|c|c|c|c|c|}
\hline \multicolumn{5}{|c|}{ PRODUTOS } \\
\hline DETERMINAÇÃO & $\begin{array}{r}\text { Carne assada } \\
\text { com molho }\end{array}$ & $\begin{array}{r}\text { Lagarto com } \\
\text { aliche }\end{array}$ & $\begin{array}{r}\text { Lagarto a } \\
\text { escabeche }\end{array}$ & $\begin{array}{r}\text { Lagarto } \\
\text { Cozido } \\
\text { (fatiado) }\end{array}$ \\
\hline Coliformes a $35^{\circ} \mathrm{C}$ & $460 \mathrm{NIMP} / \mathrm{g}$ & $>1.100 \mathrm{NMP} / \mathrm{g}$ & $1.100 \mathrm{NMP} / \mathrm{g}$ & $>1.100 \mathrm{NMP} / \mathrm{g}$ \\
\hline Coliformes a $45^{\circ} \mathrm{C}$ & $<3 \mathrm{NMP} / \mathrm{g}$ & $23 \mathrm{NMP} / \mathrm{g}$ & $1.100 \mathrm{NMP} / \mathrm{g}$ & $240 \mathrm{NMP} / \mathrm{g}$ \\
\hline $\begin{array}{l}\text { Estafilococos } \\
\text { coagulase positiva }\end{array}$ & $<100$ UFC/g & $<100$ UFC/g & $<100$ UFC/g & $<100 \mathrm{UFC} / \mathrm{g}$ \\
\hline Bacillus cereus & $<100$ UFC/g & $<100 \mathrm{UFC} / \mathrm{g}$ & $<100$ UFC/g & $<100$ UFC/g \\
\hline $\begin{array}{l}\text { Clostridios sulfito } \\
\text { redutores a } 46^{\circ} \mathrm{C}\end{array}$ & $<100$ UFC/g & $<100$ UFC/g & $<100$ UFC/g & $<100$ UFC/g \\
\hline Salmonella sp & Ausente $/ 25 \mathrm{~g}$ & Ausente $/ 25 \mathrm{~g}$ & Ausente $/ 25 \mathrm{~g}$ & Ausente $/ 25 \mathrm{~g}$ \\
\hline
\end{tabular}


TABELA 7: Resultado de Análise Microbiológica de Alimentos Preparados e expostos à Venda no dia $27 / 01 / 2004$

PRODUTOS

\begin{tabular}{|c|c|c|c|c|}
\hline DETERMINAÇÃO & $\begin{array}{r}\text { Carne assada } \\
\text { com molho }\end{array}$ & $\begin{array}{r}\text { Lagarto com } \\
\text { aliche }\end{array}$ & $\begin{array}{r}\text { Lagarto a } \\
\text { escabeche }\end{array}$ & $\begin{array}{r}\text { Lagarto Cozido } \\
\text { (fatiado) }\end{array}$ \\
\hline Coliformes a $35^{\circ} \mathrm{C}$ & $1.100 \mathrm{NMP} / \mathrm{g}$ & $>1.100 \mathrm{NMP} / \mathrm{g}$ & $23 \mathrm{NMP} / \mathrm{g}$ & $>1100 \mathrm{NMP} / \mathrm{g}$ \\
\hline Coliformes a $45^{\circ} \mathrm{C}$ & $93 \mathrm{NMP} / \mathrm{g}$ & $<3 \mathrm{NMP} / \mathrm{g}$ & $23 \mathrm{NMP} / \mathrm{g}$ & $460 \mathrm{NMP} / \mathrm{g}$ \\
\hline $\begin{array}{l}\text { Estafilococos } \\
\text { coagulase } \\
\text { positiva }\end{array}$ & $<100$ UFC/g & $100 \mathrm{UFC} / \mathrm{g}$ & $<100$ UFC/g & $<100 \mathrm{UFC} / \mathrm{g}$ \\
\hline Bacillus cereus & $<100 \mathrm{UFC} / \mathrm{g}$ & $<100 \mathrm{UFC} / \mathrm{g}$ & $<100$ UFC/g & $<100$ UFC/g \\
\hline $\begin{array}{l}\text { Clostridios sulfito } \\
\text { redutores a } 46^{\circ} \mathrm{C}\end{array}$ & $<100$ UFC/g & $<100 \mathrm{UFC} / \mathrm{g}$ & $<100$ UFC/g & $<100 \mathrm{UFC} / \mathrm{g}$ \\
\hline Salmonella sp & Ausente $/ 25 \mathrm{~g}$ & Ausente $/ 25 \mathrm{~g}$ & Ausente $/ 25 \mathrm{~g}$ & Ausente $/ 25 \mathrm{~g}$ \\
\hline
\end{tabular}

TABELA 8: Resultado de Análise Microbiológica de Alimentos Preparados e expostos à Venda no dia $28 / 01 / 2004$

\begin{tabular}{|c|c|c|c|c|}
\hline \multicolumn{5}{|c|}{ PRODUTOS } \\
\hline DETERMINAÇÃO & $\begin{array}{l}\text { Carne assada } \\
\text { com molho }\end{array}$ & $\begin{array}{l}\text { Lagarto com } \\
\text { aliche }\end{array}$ & $\begin{array}{l}\text { Lagarto a } \\
\text { escabeche }\end{array}$ & $\begin{array}{c}\text { Lagarto } \\
\text { Cozido } \\
\text { (fatiado) }\end{array}$ \\
\hline Coliformes a $35^{\circ} \mathrm{C}$ & $>1.100 \mathrm{NMP} / \mathrm{g}$ & $>1.100 \mathrm{NMP} / \mathrm{g}$ & $210 \mathrm{NMP} / \mathrm{g}$ & $>1.100 \mathrm{NMP} / \mathrm{g}$ \\
\hline Coliformes a $45^{\circ} \mathrm{C}$ & $15 \mathrm{NMP} / \mathrm{g}$ & $3,6 \mathrm{NMP} / \mathrm{g}$ & $3,6 \mathrm{NMP} / \mathrm{g}$ & $9,1 \mathrm{NMP} / \mathrm{g}$ \\
\hline $\begin{array}{l}\text { Estafilococos } \\
\text { coagulase positiva }\end{array}$ & $<100$ UFC/g & $<100$ UFC/g & $<100 \mathrm{UFC} / \mathrm{g}$ & $<100$ UFC/g \\
\hline Bacillus cereus & $<100 \mathrm{UFC} / \mathrm{g}$ & $<100 \mathrm{UFC} / \mathrm{g}$ & $<100 \mathrm{UFC} / \mathrm{g}$ & $<100 \mathrm{UFC} / \mathrm{g}$ \\
\hline $\begin{array}{l}\text { Clostridios sulfito } \\
\text { redutores a } 46^{\circ} \mathrm{C}\end{array}$ & $<100$ UFC/g & $<100$ UFC/g & $<100$ UFC/g & $<100 \mathrm{UFC} / \mathrm{g}$ \\
\hline Salmonella sp & Ausente $/ 25 \mathrm{~g}$ & Ausente $/ 25 \mathrm{~g}$ & Ausente $/ 25 \mathrm{~g}$ & Ausente $/ 25 \mathrm{~g}$ \\
\hline
\end{tabular}


TABELA 9: Resultado de análise microbiológica de alimentos preparados e expostos à venda no dia $11 / 02 / 2004$

\begin{tabular}{|c|c|c|c|c|}
\hline \multicolumn{5}{|c|}{ PRODUTOS } \\
\hline DETERMINAÇÃO & $\begin{array}{c}\text { Carne assada } \\
\text { com molho }\end{array}$ & $\begin{array}{l}\text { Lagarto com } \\
\text { aliche }\end{array}$ & $\begin{array}{l}\text { Lagarto a } \\
\text { escabeche }\end{array}$ & $\begin{array}{c}\text { Lagarto Cozido } \\
\text { (fatiado) }\end{array}$ \\
\hline Coliformes a $35^{\circ} \mathrm{C}$ & $>1.100 \mathrm{NMP} / \mathrm{g}$ & $>1.100 \mathrm{NMP} / \mathrm{g}$ & $\begin{array}{l}>1.100 \\
\mathrm{NMP} / \mathrm{g}\end{array}$ & $>1.100 \mathrm{NMP} / \mathrm{g}$ \\
\hline Coliformes a $45^{\circ} \mathrm{C}$ & $21 \mathrm{NMP} / \mathrm{g}$ & $240 \mathrm{NMP} / \mathrm{g}$ & $43 \mathrm{NMP} / \mathrm{g}$ & $>1.100 \mathrm{NMP} / \mathrm{g}$ \\
\hline $\begin{array}{l}\text { Estafilococos } \\
\text { coagulase } \\
\text { positiva }\end{array}$ & $<100$ UFC/g & $<100$ UFC/g & $<100 \mathrm{UFC} / \mathrm{g}$ & $<100$ UFC/g \\
\hline Bacillus cereus & $<100$ UFC/g & $<100$ UFC/g & $<100 \mathrm{UFC} / \mathrm{g}$ & $200 \mathrm{UFC} / \mathrm{g}$ \\
\hline $\begin{array}{l}\text { Clostridios sulfito } \\
\text { redutores a } 46^{\circ} \mathrm{C}\end{array}$ & $<100$ UFC/g & $<100$ UFC/g & $<100 \mathrm{UFC} / \mathrm{g}$ & $<100$ UFC/g \\
\hline Salmonella sp & Ausente $/ 25 \mathrm{~g}$ & Ausente $/ 25 \mathrm{~g}$ & Ausente $/ 25 \mathrm{~g}$ & Ausente $/ 25 \mathrm{~g}$ \\
\hline
\end{tabular}

Observação: Os limites estabelecidos pela Resolução RDC №12, referente ao item 22- Pratos Prontos Para o Consumo (alimentos prontos de cozinhas, restaurantes e similares), são:

1. Produtos à base de carnes, pescados, ovos e similares cozidos (item $22-\mathrm{a}) \rightarrow$ Coliformes a $45^{\circ} \mathrm{C}$ até $2 \times 10 / \mathrm{g}$, estafilococos coagulase positiva até $10^{3} / \mathrm{g}$, Bacillus cereus até $10^{3} / \mathrm{g}$, Clostridios sulfito redutores a $46^{\circ} \mathrm{C}$ até $10^{3} / \mathrm{g}$, Salmonella sp ausente em $25 \mathrm{~g}$

2. Sopas, caldos e molhos cozidos (item $22-\mathrm{c}$ ) $\rightarrow$ Coliformes a $45^{\circ} \mathrm{C}$ até $2 \times 10 / \mathrm{g}$, estafilococos coagulase positiva até $10^{3} / \mathrm{g}$, Bacillus cereusaté $10^{3} / \mathrm{g}$, Clostridios sulfito redutores a $46^{\circ} \mathrm{C}$ até $10^{3}$, Salmonella sp ausente em $25 \mathrm{~g}$

3. Produtos à base de cereais, farinhas, grãos e similares; saladas mistas temperadas ou não, com ou sem molho, exceção das adicionadas de molho de maionese e similares (item 22-d) $\rightarrow$ Coliformes a $45^{\circ} \mathrm{C}$ até 
$10^{2} / \mathrm{g}$ estafilococos coagulase positiva até $10^{3} / \mathrm{g}$, Bacillus cereus até $10^{3} / \mathrm{g}$, Salmonella sp ausente em $25 \mathrm{~g}$

4. Produtos à base de verduras, legumes, raízes, tubérculos e similares cozidos, temperados ou não (item 22-e) $\rightarrow$ Coliformes a $45^{\circ} \mathrm{C}$ até $5 \times 10 / \mathrm{g}$, estafilococos coagulase positiva até $10^{3} / \mathrm{g}$, Bacillus cereus até $10^{3} / \mathrm{g}$, Salmonella sp ausente em $25 \mathrm{~g}$

5. Saladas adicionadas de molho de maionese e similares (item-f) $\rightarrow$ Coliformes a $45^{\circ} \mathrm{C}$ até $10^{2} / \mathrm{g}$, estafilococos coagulase positiva até $10^{3} / \mathrm{g}$, Salmonella sp ausente em $25 \mathrm{~g}$

Conforme os resultados acima, pode-se verificar que algumas das preparações apresentaram resultado microbiológico insatisfatório, estando em desacordo com a Resolução da ANVISA RDC N¹2, que aprova o Regulamento Técnico sobre Padrões Microbiológicos Para Alimentos. Os produtos com o pior resultado foram o lagarto com aliche, lagarto a escabeche, lagarto cozido (sem a adição de molho escabeche ou aliche) e a carne assada com molho. Deve-se ressaltar, no entanto que nenhum dos produtos analisados foi positivo para patógenos como Salmonella, Bacillus cereus e estafilococos cogulase positiva.

Das 8 amostras da carne assada com molho, $3(37 \%)$ não atenderam a RDC NN12. Das 7 amostras de lagarto com aliche, $3(43 \%)$ não estavam em acordo com essa Resolução. Das 7 amostras de lagarto a escabeche, 5 (71\%) estavam em desacordo com a RDC N¹2. Das 5 amostras de lagarto fatiado apenas uma estava de acordo com os padrões da RDC N¹2. Em todas as amostras em desacordo com a Resolução RDC N012 referente aos item 22-Pratos Prontos Para o Consumo 
(alimentos prontos de cozinhas, restaurantes e similares) a causa foi o NMP/g de Coliformes a $45^{\circ} \mathrm{C}$, que foi superior ao limite estabelecido. 


\section{3 - INTERPRETAÇAO DE RESULTADOS}

Embora o número de amostras submetidas à análise microbiológica seja limitado, verifica-se que a seção de rotisseria desse supermercado comercializa produtos prontos para o consumo que não atendem a legislação vigente (RDC N 12) e, portanto, podem representar um perigo à saúde dos consumidores. A lista de verificação também comprovou que uma boa parte $(69 \%)$ dos itens classificados como "IMPRESCINDÍVEL" não foi atendido. O mesmo aconteceu com os itens classificados como "NECESSÁRIO". Entre os itens "RECOMENDÁVEL", nenhum foi atendido. Durante a realização deste estudo, foi possível verificar que há um grande número de profissionais que atuam neste setor que não possuem treinamento prévio para manipular alimentos. Segundo Germano $(2001,2003)$, a capacitação de manipuladores possui um papel importante no sentido de minimizar a ocorrência de contaminação de alimentos. O treinamento de manipuladores é recomendado como uma medida eficiente e econômica. O treinamento como atividade educativa pode desempenhar um papel de destaque na promoção da saúde e evitar doenças transmitidas por alimentos.

Os resultados desse estudo são preocupantes porque crescem as informações de casos de DTA envolvendo alimentos preparados ou fornecidos nestes tipos de estabelecimentos. Segundo o Centro de Vigilância Sanitária Municipal de São Paulo (2004, comunicação pessoal), existem casos de denúncias de consumidores envolvendo salgados fritos ou assados, frango assado, arroz, farofa e maionese, como suspeitos de causar vômitos, diarréia e febre.

Um dos problemas ocorridos no ano de 2004 envolveu dois consumidores que compraram e consumiram "salgados prontos", fritos e assados num estabelecimento na Zona Norte da cidade. De acordo com os relatórios da 
autoridade sanitária (SMS/SP, comunicação pessoal), o principal sintoma apresentado pelos doentes foi o vômito pouco tempo após o consumo. Os produtos suspeitos eram croquete de carne, bolinho de queijo e de bacalhau. Os resultados de análise microbiológica indicaram que o bolinho de queijo tinha contagem de estafilococos coagulase positiva acima do permitido pela Resolução RDC $n^{\circ} 12$. O produto implicado era fornecido congelado por uma empresa e frito e exposto ao consumidor no supermercado. Na inspeção deste estabelecimento e de sua seção de rotisseria, a autoridade sanitária fez as seguintes observações do local:

"No momento da visita foi constatado que:

1- funcionários da seção de fiambreria' apresentavam unhas compridas e anéis;

2- Neste local eram expostos para venda salgados fritos e assados prontos para o consumo. Os produtos não estavam em temperatura controlada, estavam expostos à venda em temperatura ambiente;

3- Não havia equipamentos para controle de temperaturas; [...]

4- O local apresentava higiene inadequada nos balcōes e bancadas que entram em contato com os alimentos;

5- Não foi apresentado Manual de Boas Práticas [...]

Mais dois casos foram relatados pela Vigilância Municipal (SMS/SP, comunicação pessoal). Num deles, uma família inteira (5 adultos e 2 crianças) adoeceu. O produto envolvido era frango assado comprado em um estabelecimento supermercadista ${ }^{2}$. Os sintomas apresentados pelos doentes foram diarréia, dor de estômago, dor de cabeça, febre e tremores. O produto comprado não foi consumido

\footnotetext{
${ }^{1}$ Seção de fiambreria- Alguns supermercados utilizam este termo para descrever a seção de frios e laticínios

2 Este produto é bastante comum em estabelecimentos varejistas. É preparado principalmente em finais de semana.
} 
de imediato. Permaneceu em temperatura ambiente na residência e consumido algumas horas depois. Restos dos alimentos foram analisados no laboratório oficial do órgão, apresentando resultado positivo para Salmonella sp.

Casos de contaminação de alimentos em supermercados já foram relatados anteriormente por Motta e Belmonte (2000) na região oeste do Município de São Paulo. Numa avaliação microbiológica de carne moída crua, foi verificada a presença excessiva de bactérias mesófilas e de coliformes totais e fecais em $60 \%$ das amostras analisadas; encontrou-se ainda uma amostra contaminada por Salmonella sp. e outra por Staphylococcus aureus.

Os dados do presente estudo corroboram os dados constatados por Valente (2001) que verificou que $79 \%$ dos supermercados da região de Ribeirão Preto foram classificados como "deficientes" porque apresentavam uma condição higiênicosanitária e físico-estrutural em desacordo com a legislação vigente da região (VALENTE, 2001).

Verifica-se que o problema detectado nesse estudo já é de conhecimento dos órgãos competentes. A Vigilância Sanitária do Estado de São Paulo instituiu o "Programa Paulista de Análise Fiscal de Alimentos", cujos os resultados mostram que o setor apresenta sérias deficiências e que precisa adotar com urgência as BPMS (SEMINÁRIO DE SEGURANÇA DOS ALIMENTOS DA APAS, 2005).

Este não é um problema exclusivo do Brasil. Também nos Estados Unidos, foi verificado que alguns estabelecimentos apresentam não conformidades com as recomendações de Boas Práticas de Manipulação de Alimentos conforme o relato do FDA - Report on the Occurrence of Foodborne Illness Risk Factors in Selected Institutional Foodservice, Restaurant, and Retail Food Store Facility Types (FDA, 2004). Os maiores problemas estão relacionados com o controle do tempo e 
temperatura na exposição de alimentos, higiene pessoal, higiene dos equipamentos, proteção dos alimentos de contaminação, cocção dos alimentos e origem dos alimentos. Destes itens aqueles que precisam de maior atenção em delis ${ }^{3}$ por representarem um fator de risco para o desenvolvimento de DTA são a combinação inadequada de tempo e temperatura (64\%) de armazenamento, a falta de higiene pessoal $(23,5 \%)$, os equipamentos contaminados ou sem proteção de contaminação $(23,4 \%)$ e, por último, os produtos químicos (21,9\%) (FDA, 2004).

\footnotetext{
${ }^{3}$ Tipo de loja varejista de alimentos muito comum nos EUA onde é possivel encontrar alimentos nronntne a nitrne nara n nronorn ia rafainñoc
} 


\section{6 - CONCLUSÕES}

A avaliação feita nesse estudo possibilitou verificar que a seção de rotisseria do supermercado estudado apresentou uma série de deficiências no atendimento aos itens da lista de verificação das Boas Práticas de Manipulação em Estabelecimento da Área de Alimentos (LVBPMEA) e vários alimentos prontos para o consumo não estavam de acordo com os critérios microbiológicos da Resolução RDC $\mathrm{n}^{\circ 12}$ da ANVISA. Portanto, ficou evidente que a seção de rotisseria de supermercados necessita de maior atenção tanto pelos empresários supermercadistas como pelos consumidores e orgãos governamentais de fiscalização, especialmente porque esse serviço atende à crescente demanda dos consumidores que se utilizam dos supermercados para adquirir refeições prontas para o consumo. 


\section{7- REFERÊNCIAS BIBLIOGRÁFICAS}

AFIC (ASIAN FOOD INFORMATION CENTRE). What Should You Know About Foodborne IIIness, 2000; Disponivel em http://www.afic.org/Food\%20bourneillness.pdf , acesso em: 02/10/04

ALENCAR, L. C. M., Vigilância e Controle das doenças transmitidas por alimentos. 2002. 120p. Dissertação (Mestrado)-Faculdade de Saúde Pública, Universidade de São Paulo, São Paulo, 2002

ANVISA (AGÊNCIA NACIONAL DE VIGILÂNCIA SANITÁRIA). Programa Nacional de Monitoramento da Qualidade Sanitária de Alimentos: 2003. Disponivel em: http://www. anvisa.gov.br/alimentos/programa/criterios. htm acessado em: 05/01/2005

ANVISA (AGÊNCIA NACIONAL DE VIGILÂNCIA SANITÁRIA).Encefalopatia Espongiforme Transmissivel, Caderno Técnico, Brasilia 2004, p.17

ANVISA (AGÊNCIA NACIONAL DE VIGILÂNCIA SANITÁRIA). Resolução RDC $n^{0}$ 216, de 15 de setembro de 2004. Dispõe sobre o Regulamento Técnico de Boas Práticas para Serviços de Alimentação.Disponivel em: http// www.anvisa.gov.br acessado em: 05/30/2003

ANVISA (AGẼNCIA NACIONAL DE VIGILÂNCIA SANITÁRIA). Resolução RDC $n^{\circ}$ 12, 02/01/2001. Aprova o Regulamento Técnico Sobre Padrões Microbiológicos para Alimentos. Disponivel em: http// www.anvisa.gov.br acessado em: 05/30/2003 
ARAÚJO, L. Supermercados investem nas refeições prontas como opção para as datas festivas. Jornal "O Globo". Caderno Economia, Rio de Janeiro. 03/04/1999. pg 18. Clipping da Abras

ASSOCIAÇÃO BRASILEIRA DAS INDÚSTRIAS DE ALIMENTAÇÃO. A nova distribuição para o food service brasileiro. São Paulo; 2004. [Apostila do Curso de Distribuição para o Food Service Brasileiro]

ASSOCIAÇÃO BRASILEIRA DE ENGENHEIROS DE ALIMENTOS. Código de Defesa do Consumidor - Direcionado ao Segmento Alimentício . São Paulo; 2003. ABEA

ASSOCIAÇÃO BRASILEIRA DE SUPERMERCADOS. Setor Mostra sua Força em Ano Difícil. Revista SuperHiper, Maio de 2004, Ano 39 - Número 342, São Paulo.154 p.

ASSOCIAÇÃO BRASILEIRA DE SUPERMERCADOS. Anais FMI 97-As princpais palestras proferidas durante a convenção anual do FMI. São Paulo, 1997; Jornal Comunicações

ASSOCIAÇÃO BRASILEIRA DE SUPERMERCADOS. Tabela de Classificação dos Estabelecimentos Varejistas de Alimentos. São Paulo, 2004. Disponivel em: www.abrasnet.com.br

ASSOCIAÇÃO BRASILEIRA DE SUPERMERCADOS. Contaminação na Ponta do Iceberg (resumo de palestras da $34^{\mathrm{a}}$ Convenção Nacional de Supermercados), Revista SuperHiper, ano 26, n³02, p. 74-76, outubro de 2000. 
ASSOCIAÇÃO BRASILEIRA DE SUPERMERCADOS. Segurança Alimentarcomo conquistar o cliente pela confiança (35 $5^{\mathrm{a}}$ Convenção Nacional de Supermercados), Revista SuperHiper, ano 27, $n^{\circ} 313$, setembro de 2001, p. 10-17

ASSOCIAÇÃO PAULISTA DE SUPERMERCADOS. Seminário de segurança dos alimentos: Resumo das palestras. São Paulo: APAS, 2005. 50p.

BELLENZANI, J.R.L. Descrição de Sistema da Qualidade para a Indústria de produtos Derivados de Carne. 2004. 84p. Dissertação (Mestrado) - Faculdade de Engenharia Mecânica, Universidade Estadual de Campinas, Campinas,2004

BLACKWELL, R.D.; MINIARD, P.W.; ENGELL, J.F. Comportamento do Consumidor. $9^{\mathrm{a} e d ;}$ São Paulo. Pioneira Thomson, 2005. 606p.

BRASIL. Leis e Decretos. Código De Defesa do Consumidor. Lei 8078 de 11 de setembro de 1990. Dispõe sobre a Proteção do Consumidor e dá outras Providências. Diário Oficial da União de 12 de setembro de 1990.

BRASIL. Ministério da Saúde. Portaria no 1428, de 26 de novembro de 1993. Aprova o Regulamento Técnico para a Inspeção de Sanitária de Alimentos, Diretrizes para o Estabelecimento de Boas Práticas de Produção e de Prestação de Serviços na Área de Alimentos. Disponivel em: http// www.anvisa.gov.br acesso em 02/03/2003

BRASIL. Secretaria de Vigilância Sanitária. Portaria n 326, 30 de julho de 1997. Aprova o Regulamento Técnico sobre as Condições Higiênico Sanitárias e de Boas Práticas de Fabricação para Estabelecimentos Produtores I industrializadores de Alimentos. Disponivel em: http// www.anvisa.gov.br acesso em 02/03/2003 
BRASIL, Resolução Na35. CNPPA - Comissão Nacional de Normas e Padrões para Alimentos; Disponivel em: $\underline{\text { http:/le- }}$ legis.bvs.br/leisref/public/showAct.php?id=6322, acessado em: 04/01/2005

BRASIL, Ministério da Saúde. Portaria $n^{0} 710$, de 10 de junho de 1999. Aprova a Política Nacional de Alimentação e Nutrição. D.O. U. ; Poder Executivo, 15 de juriho de 1999

BRITO, D. Rotisseria: lucro ou tráfego? REVISTA SUPERVAREJO, $\mathrm{n}^{\circ} 56$, dezembro de 2004, São Paulo, p. 44-45, APAS, 82p

BRYAN, F.L. Factors that contribute to outbreaks of foodborne disease. J. Food Protection, Des Moines, v.41, n.10, p.816-827,1978.

BRYAN, F.L. Hazard analysis critical control point approach:epidemiologic rationale and application to foodservice operations. J. Environ. Health, Denver, v.44, n.1,p.7-14, 1981

BRYAN, F.L. Risk of pratices, procedures and process that lead to outbreaks of foodborne diseas . J. Food Prot. Des Moines, v.51, n.8, p.663-673, 1988

BRYAN, F.L., Application of HAACCP to read-to-eat chilled foods. Food Technol., Chicago, n.7, p.70-77, 1990

CAMPOS, V. F. Controle da Qualidade Total (No Estilo Japonês). Belo Horizonte:Fundação Christiano Ottoni, 1992. 229 p.

CARVALHO, D. A explosão do food service. REVISTA SUPERMERCADO MODERNO; ano 36.n 3, p.25-38. março de 2005. 70p. 
CASCUDO, L.C. História da alimentação no Brasil. 3ed. São Paulo: Global, 2004. $954 p$.

CENTRO DE VIGILÂNCIA EPIDMIOLÓGICA. Programa de monitoramento da qualidade de alimentos e água coordenados pelo Centro de Vigilância Sanitária do Estado de São Paulo. Boletim Informativo. São Paulo, 2002. Ano 17, $n^{0} 60$, setembro de $2002,38 p$

CENTRO DE VIGILÂNCIA EPIDMIOLÓGICA. Doenças transmitidas por alimentos. Dados estatísticos. DTA - dados dos surtos de DTA notificados - 2003 por DIR e município em planilha. Disponivel em: http://www.cve.saude.gov.br acesso em $30 / 03 / 2004$

CYRILLO, D.C.O papel dos Supermercados no varejo de alimentos. São Paulo; Monografia, 1987, 198p, Faculdade de Administração e Economia, Universidade de São Paulo, 1987

DALLARI, S.G. Vigilância Sanitária de alimentos de Consumo Imediato no Município de São Paulo: a importância da informação para o planejamento. Higiene alimentar, v. 14, n. 76, p. $24-35,2000$

DIAS, H.P. Direitos e Obrigações em Saúde; Brasília. 2002; ANVISA, 387 p.

FERREIRA, A.B. H. Miniaurélio Século XXI: $O$ minidicionário da língua portuguesa.4 ed. Rio de Janeiro: Editora Nova Fronteira, 2000.790 p.

FLANDRIN, J.L; MONTANARI, M. História da Alimentação, 2ed. São Paulo, Estação Liberdade, 2000. 885p. 
FMI (FOOD MARKETING INSTITUTE). FOOD SAFETY. Washington;2004 disponível em http://www.fmi.org/foodsafety acessado em:20/09/2004

FMI (FOOD MARKETING INSTITUTE); ALAS (ASOCIACION LATINOAMERICANA DE SUPERMERCADOS); ABRAS (ASSOCIAÇÃO BRASILEIRA DE SUPERMERCADOS). Tendências no Brasil: Atitudes/ comportamento do consumidor no supermercado. Washington (DC): Food Marketing Institute:1999,102p

FOOD AND AGRICULTURAL ORGANIZATION/ WORLD AND HEALTH ORGANIZATION . Expert Consultation on Risk Assessment of Microbiological Hazards in Foods, Exposure assessment of Salmonella spp. in brolers, FAO Headquarters, Rome, Italy, 17-21 July 2000. Disponivel em http://www.cfsan.fda.gov/ acessado em: 30/04/2003

FOOD AND DRUG ADMINISTRATION. Title 21 Code of Federal Regulations. Part 114. Washington U.S. Government Printing Office, 1999. Disponivel em: http://www.cfsan.fda.gov/ acessado em: 05/11/2004

FOOD AND DRUG ADMINISTRATION; CONFERENCE FOR FOOD PROTECTION. Food Establishment Plan Review Guideline. Plan Review Development Committee for the Conference for Food Protection. 160p, 2000. Disponível em: http://www.cfsan.fda.gov/ dms/prev-toc.html acessado em:25/10/2003

FOOD AND DRUG ADMINSTRATION, FDA Report on the occurrence of food born illness risk factors in selected institutional food service, restaurant and retail food store facility types (2004), Disponível em http://www.cfsan.fda.gov/ acessado em: 30/11/2004 
FOOD AND DRUG ADMINSTRATION/ CENTER FOR FOOD SAFETY AND APPLIED NUTRITION. Managing Food Safety: A HACCPP Principles Guide for Operators of Food Establishments at the Retail Level, Disponível em: http//www.cfsan.fda.gov/ acessado em: 05/02/2004

FORSYTHE, S.J. Microbiologia da segurança alimentar. Porto Alegre: Artemed; 2002. 260p.

FRANCO, B.D.M., Seminário de Segurança dos Alimentos, SENAI, Centro de Tecnologia de Alimentos e Bebidas, Vassouras, 2004, CD ROOM

FRANCO, B.D.G.M.; LANDGRAF, M. Microbiologia de Alimentos. São Paulo: Atheneu, 1996, 182p

GAZETA MERCANTIL, Vida moderna altera os padrões alimentares: cada vez mais, brasileiros dos grandes centros passam a consumir alimentos prontos ou semi-prontos, São Paulo, 03/01/1999, Empresas \& Negócios, p.12. Clipping Abras

GERMANO, Maria Izabel S.; RENCINAI, Solange T.; GERMANO, Pedro Manuel L. Grau de Informação dos Manipuladores de Alimentos em Pequenas e Médias Empresas da Cidade de São Paulo, Higiene Alimentar v.15, n.80/81, p.94, 2001.

GERMANO,P.M.L.;GERMANO, M.I.S.Higiene e Vigilância Sanitária de Alimentos, São Paulo: Livraria Varela, 2001.629p

GERMANO, Maria Isabel Simões, Treinamento de Manipuladores de Alimentos: Fator de Segurança Alimentar e Promoção da Saúde. São Paulo: Livraria Varela, 2003.165p

GONÇALVES, J. Perecíveis em alta: REVISTA SUPER HIPER - Ano 26-Número 296 - Abril de 2000. p.46-55 
HANASHIRO, A. Avaliação da qualidade higiênico-sanitária e nutritiva de bentôs comercializados no bairro da Liberdade em São Paulo, 126p, 2002, Dissertação(Mestrado),São Paulo,PRONUTRI (Curso de Pós-Graduação Interunidas em Nutrição Humana Aplicada), FCF-FEA-FSP, Universidade de São Paulo, 2002

INSTITUTE OF FOOD TECHNOLOGISTS. Bacteria and foodborne diseases: safety can be influenced at home and in foodservice. 2004, disponivel em: http://www.ift.org/cms acessado em:04/01/2005

JAY, J.M. Modern food microbiology. Maryland: Aspen Publishers, 2000. 679 p

JORNAL DA TARDE. Supermercado também tem self. Caderno Seu Dinheiro. 13/07/2004. p.8D, São Paulo, Clipping Abras

JURAN, J.M. A Qualidade desde o Projeto: novos passos para o planejamento da qualidade em produtos e serviços.São Paulo:Editora Pioneira, 1992

KAWASAKI, V.M. Custo-efetividade da produção de refeições coletivas seguras sob o aspecto higiênico sanitário em sistemas cook-chill e tradicional. $89 p$. São Paulo, 2003 Dissertação (Mestrado\}. PRONUTRI (Curso de Pós-Graduação Interunidas em Nutrição Humana Aplicada), FCF-FEA-FSP, Universidade de São Paulo, 2003

LAMPERT, P. Compreendendo o consumidor de hoje e de amanhã. ABRAS;FMI, 1997. In: As principais palestras proferidas durante a convenção anual do FMI. Jornal Comunicações.112p

LOPES, E. A. Análise de perigos e pontos críticos de controle (APPCC/HACCP) na produção de farinha de trigo: estudo microbiológico da etapa de molhagem do trigo. 91p. 2002, São Paulo; Dissertação (Mestrado) - Faculdade Ciências Farmacêuticas da Universidade de São Paulo, 2002 
LOPES, E. A. Guia Para elaboração dos procedimentos operacionais padronizados, Exigidos pela RDC n²75 da ANVISA, São Paulo: Livraria Varela , $2004,236 p$.

LUKIANOCENKO, M. Perecíveis: soluções que ampliam lucros. Revista SuperHiper, ano 31, n³ 350, p. 74-76, fevereiro de 2005.

MARQUES, Maria Cristina et al, organizadores, Casos e fatos da Vigilância Sanitária sobre a saúde na sociedade. São Paulo: Sobravime, CVS, 2002, pag 198-209

MOTTA M.R.A.; BELMONTE, M.A. Avaliação Microbiológica de amostras de carne moída comercializadas em supermercados da região oeste de São Paulo. Revista Higiene Alimentar 2000;14(78/79):59-62

MOWEN, I.C.MINOR, M.S. Comportamento do Consumidor. São Paulo;Prentice Hall, 2004, 394p

ORGANIZAÇÃO MUNDIAL DA SAUDE. Food safety and foodborne illness. Disponivel em: http://www.who.int/inf-fs/en/fct237.html

ORGANIZAÇÃO PAN-AMERICANA DE SAÚDE. Segurança Sanitária no mundo Globalizado. Washington; OPAS; 2001. 230 p.(OPAS-Séries Informes Técnicos, 74)

PARENTE, J. Varejo no Brasil. São Paulo:Editora Atlas, 2.000. 388p.

PAULA, L. Segurança dos Alimentos em Debate, Revista Supervarejo, $n^{\circ} 58$ abril de 2005, São Paulo, APAS, 82p

PERDIGÃO, Comida Fresca. Revista Perdigão Hoje, n50, Janeiro- 2005, São Paulo, Editora Perdigão Agroindustrial 
PRAXEDES, P.C..Aspectos da qualidade higiênico-sanitária de alimentos consumidos e comercializados na comunidade de São Remo, São Paulo. 120p 2003.São Paulo. Dissertação (Mestrado)-Faculdade de Medicina Veterinária e Zootecnia . Universidade de São Paulo. 2003

PROVAR; FIA; FEA; USP. Relatório de Hábitos de Compra nos Supermercados Paulistanos, São Paulo, 1997. USP. 31p

PROVATTI, Roberta. Eficiência em sistemas de refrigeração comercial. Revista Abrava. 2005, $n^{a} 222$. ano $29,50 p$

RODRIGUES, M., ABRAS. Supermercados 40 anos. São Paulo: Ícone Pesquisas de História e ABRAS, 1993.186p.

SÃO PAULO (Estado), Leis, etc. CÓDIGO SANITÁRIO DO MUNICíPIO DE SÃO PAULO-Lei $\mathrm{N}^{0}$ 13725, de 9 de Janeiro de 2004. Disponível em: http//www.prefeitura.sp.gov.br acesso em:15/10/2004

SÃO PAULO (Estado), Leis, etc. PORTARIA CVS nº 6 de 10 de março de 1999Aprova o Regulamento Técnico sobre os Parâmetros e Critérios para o Controle Higiênico Sanitário em Estabelecimentos de Alimentos. Disponivel em:

http// www.cvs.sp.gov.br

SÃO PAULO (Município), Leis, etc. PORTARIA 2.535/03-SMS.G de 24 de outubro de 2003. Secretaria Municipal de Saúde - Aprova o Regulamento Técnico para o Controle Higiênico-Sanitário em Empresas de Alimentos, estabelecendo critérios e parâmetros para a produção de alimentos e bebidas, aplicados às empresas de alimentos.Disponível em: http// www.prefeitura.sp.gov.br 
SÃO PAULO (Município), Leis, etc. PORTARIA 2.536/03-SMS.G de 24 de outubro de 2003. Secretaria Municipal de Saúde - Define as principais Atividades e Características do Comércio Varejista de Alimentosem Consonância com o Código Nacional de Atividades Econômicas - CNAE Disponível em: http// www.prefeitura.sp.gov.br

SÃO PAULO (Município), Leis, etc. Secretaria Municipal de Saúde - Decreto 42.740 - de 20 de dezembro de 2002- DISCIPLINA O CADASTRO MUNICIPAL DE VIGILÂNCIA SANITÁRIA, estabelece os procedimentos administrativos de vigilância em saúde e dá outras providências . D.O.M. de 21 de dezembro de 2002

SÃO PAULO (Município). Secretaria Municipal de Abastecimento/Departamento de Inspeção Municipal de Alimentos. APOSTILA DO MONITOR: Projeto de Parceria em Educação Sanitaria. São Paulo, de 24 de outubro de 2002. 35p

SÃO PAULO (Município). Secretaria Municipal de Abastecimento/Departamento de Inspeção Municipal de Alimentos. Lista de verificação das Boas Práticas de Manipulação em Estabelecimentos da Área de alimentos. São Paulo, 2002. Disponível

em: http://www2.prefeitura.sp.gov.br/secretarias/abastecimento/organizacao/estrutura/vig ilancia sanitaria/resumo mensal/resumo mensal

SÃO PAULO (Município). Secretaria Municipal de Abastecimento. I Conferência Municipal de Segurança Alimentar e Nutricional de São Paulo. Caderno de resumos. São Paulo, 9 de dezembro de 2001. 30p

SERVIÇO NACIONAL DE APRENDIZAGEM.Guia para elaboração do Plano APPCC. Série Qualidade e Segurança Alimentar.Projeto APPCC. Brasilia,1999. 371p 
SERVIÇO NACIONAL DE APRENDIZAGEM. Manual de Segurança e Qualidade na Distribuição de Alimentos - Rotisseria Série Qualidade e Segurança Alimentar. PAS. Brasilia, 2004. 80 p

SILVA JÚNIOR, E.A. Manual de controle higiênico-sanitário em alimentos. 4ed.São Paulo:Varela, 2001.477p

SOUZA, W. , Congelados: conveniência que vem do frio. REVISTA SUPER HIPER. São Paulo- Ano 29, Número 334, Agosto de 2003, p. 14-16

SPERS, E. E. Mecanismos de regulação da qualidade e segurança em alimentos. São Paulo, 116p,2003. Tese (Doutorado).Departamento de Administração da Faculdade de Economia, Administração e Contabilidade, Universidade de São Paulo, 2003

TORRES, E.A.F.S., MACHADO, F.M.S. Alimentos em questão: uma abordagem técnica para as dúvidas mais comuns, São Paulo: Editora Ponto Crítico, 2001, 80p.

TURCATO, S. O Mundo dos Congelados. Correio Brasilense, Brasília, 10/12/2002, Caderno Consumidor, p.2. Clipping Abras

VALENTE, D. Avaliação higiênico-sanitária e físico-estrutural dos supermercados de Ribeirão Preto. 150p, 2001.Ribeirão Preto. Dissertação (Mestrado). Faculdade de Medicina de Ribeirão Preto.Universidade de São Paulo, 2001 
VICTALINO, M.F.P.J. Pesquisa de satisfação do consumidor utilizando-se o Método Kitano - uma abordagem para produtos alimentícios recém lançados. 139p, São Paulo, 2004. Dissertação (Mestrado) - Faculdade de Ciências Farmacêuticas. Universidade de São Paulo, 2004

VIO, F. Teste do IDEC avalia a qualidade de produto congelado. Jornal da Tarde. Caderno Consumo.São Paulo. 02/03/2002.Clipping ABRAS

ZANARDI, A.M.P. Avaliação da qualidade microbiológica de refeições servidas a bordo de aeronaves. 93 p, São Paulo, 2002. Tese (Doutorado) - Faculdade de Saúde Pública, Universidade de São Paulo 


\section{Cardápio da Rotisseria}

1. Abóbora com camarão

2. Abóbora recheada

3. Abobrinha a vinagrete

4. Abobrinha recheada

5. Alcachofra baby ao vinagrete

6. Alichella à moda

7. Almôndegas à moda ao molho

8. Arroz à grega

9. Arroz branco

10. Arroz com bacalhau

11. Arroz com camarão

12. Arroz carreteiro

13. Bacalhau ao forno

14. Bacalhau voador

15. Batata ao parmesão

16. Batata doce frita

17. Berinjela a parmegiana

18. Berinjela recheada com atum

19. Bife a role ao molho

20. Bife à milanesa pronto

21. Bife a parmegiana pronto

22. Bisteca suína pronta

23. Brócoli ao alho e óleo

24. Caldo verde

25. Capponata

26. Carne assada

27. Carne louca

28. Carne recheada

29. Carne seca acebolada

30. Carne seca com abóbora 
31. Chilli à moda

32. Chop suey

33. Compota chic à moda

34. Compota de maçã

35. Costelinha ao forno

36. Costelinha assada com batatas

37. Couve flor com molho branco

38. Coxa/Sobrecoxa a passarinho

39. Coxa/Sobrecoxa assados

40. Coxa/Sobrecoxa com batatas

41. Cremes sortidos

42. Croquete de carne

43. Cuscuz

44. Doce de abóbora

45. Doce de batata doce

46. Espetinho de carne bovina

47. Espetinho de frango

48. Farofa à moda

49. Feijão tropeiro

50. Feijão à moda

51. Feijoada light à moda

52. Filé de pescada

53. Filé de frango grelhado

54. Filé de frango recheado

55. Filé de pescada com ervas finas

56. Filé de pescada ao molho de alcaparras

57. Frango assado com batatas

58. Frango di Parma

59. Frango ensopado com batatas

60. Frango xadrez

61. Hambúrguer recheado

62. Isca de berinjela à moda

63. Kibe assado 
64. Kit feijoada light à moda completo

65. Lagartella

66. Lagarto ao escabeche

67. Lagarto ao molho madeira

68. Lagarto com aliche e azeitonas

69. Lagarto recheado e fatiado

70. Lasanha à moda

71. Legumes ao alho e óleo

72. Legumes sauté

73. Legumes variados

74. Lombo assado com batatas

75. Lombo assado recheado agridoce

76. Lombo assado recheado salgado

77. Macarronada

78. Maionese à moda

79. Maminha ao forno

80. Marmitex funcionário grande

81. Marmitex funcionário pequena

82. Massa à moda (rondelle/ canellone)

83. Medalhão frango

84. Mini salada à moda

85. Molhos Sugo e Branco

86. Negritas

87. Nhoque à moda

88. Panquecas de carne/presunto e queijo

89. Panquecas de palmito

90. Panquecas de ricota/espinafre e frango/catupiry

91. Peito de peru assado

92. Pernil assado

93. Pernil fatiado

94. Pernil à moda

95. Pescado surpresa

96. Picanha à moda 
97. Pimentão à moda

98. Polenta ao molho

99. Polenta frita

100. Postas de cação ao molho

101. Postas de cação ao molho de alcaparras

102. Purê de batatas

103. Quiche de queijo

104. Rabada ao molho

105. Recheadinho

106. Salada de frios

107. Salada de grão de bico

108. Salada de legumes

109. Salada de macarrão com atum

110. Salada à moda

111. Salgadinhos

112. Sobrecoxa empanada ao forno

113. Sopa de ervilhas

114. Sopa de legumes

115. Strogonoff de carne

116. Strogonoff de frango

117. Tender assado sem ossos

118. Torta de batata com palmito

119. Torta de batata

120. Torta especial de palmito 